U.S. Department of the Interior

U.S. Geological Survey

\title{
Trends and Status of Flow, \\ Nutrients, and Sediments \\ for Selected Nontidal Sites in the \\ Chesapeake Bay Watershed, 1985-98
}

By Michael J. Langland, U.S. Geological Survey,

Joel D. Blomquist, U.S. Geological Survey,

and Lori A. Sprague, U.S. Geological Survey,

and Robert E. Edwards, Susquehanna River Basin Commission

Open-File Report 99-451 


\title{
U.S. DEPARTMENT OF THE INTERIOR
}

\section{BRUCE BABBITT, Secretary}

\author{
U.S. GEOLOGICAL SURVEY
}

\author{
Charles G. Groat, Director
}

For additional information

write to:

District Chief

U.S. Geological Survey

840 Market Street

Lemoyne, Pennsylvania 17043-1586
Copies of this report may be

purchased from:

U.S. Geological Survey

Branch of Information Services

Box 25286, Federal Center

Denver, Colorado 80225-0286 


\section{CONTENTS}

Page

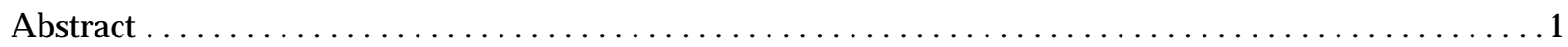

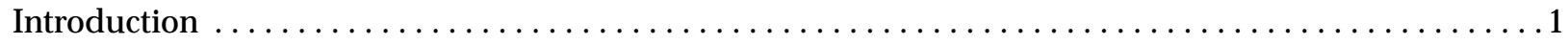

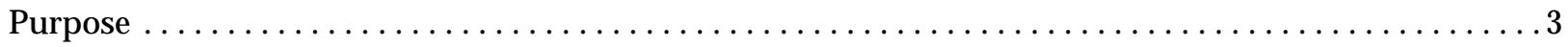

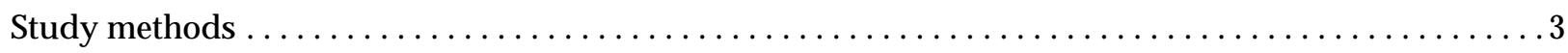

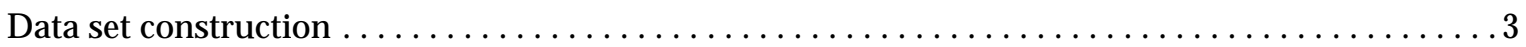

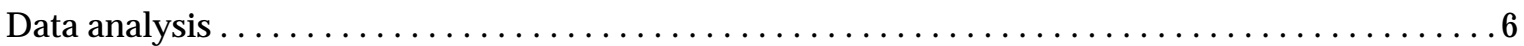

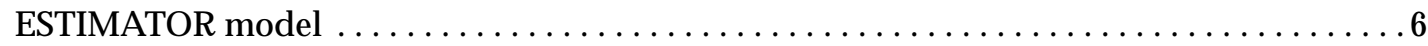

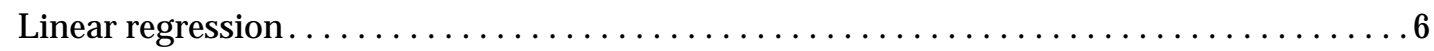

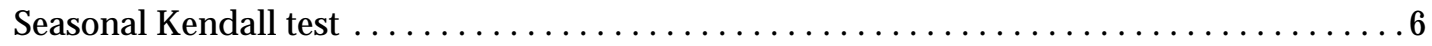

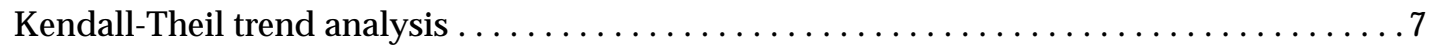

Detection and trend reporting of censored data. . . . . . . . . . . . . . . . . . . . . 7

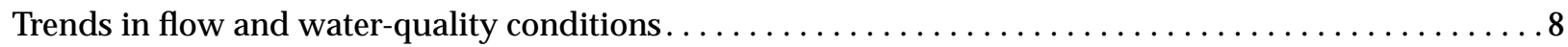

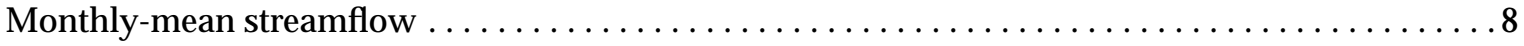

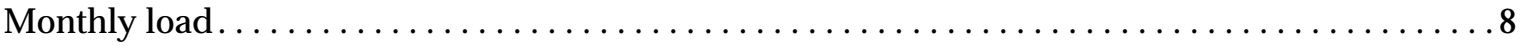

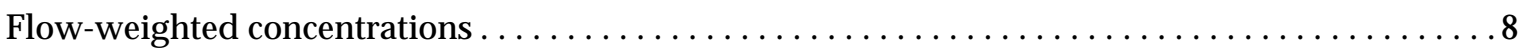

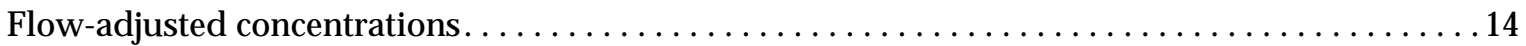

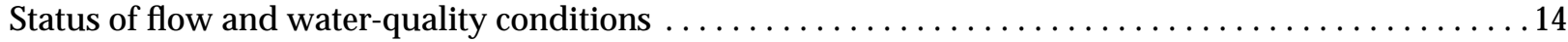

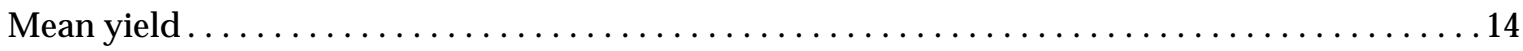

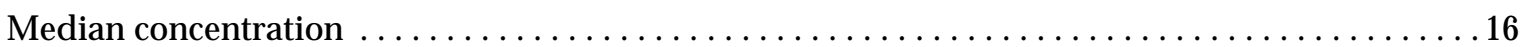

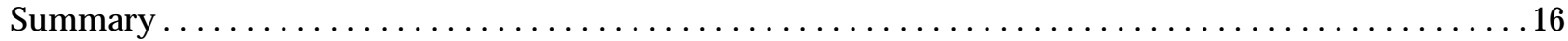

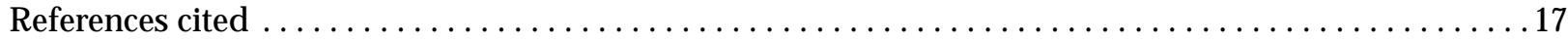

Appendix 1. Trends in streamflow and load data for 9 River Input Monitoring Program sites and 21 Multi-Agency Nontidal Program sites in the Chesapeake Bay Watershed. . . . . . . . . . . 18

Appendix 2. Trends in flow-weighted concentration data for 9 River Input Monitoring Program sites and 21 Multi-Agency Nontidal Program sites in the Chesapeake Bay

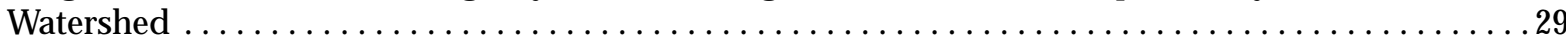

Appendix 3. Trends in flow-adjusted concentration data for 9 River Input Monitoring Program sites and 21 Multi-Agency Nontidal Program sites in the Chesapeake Bay Watershed 


\section{ILLUSTRATIONS}

Page

Figures 1-3. Maps showing:

1. Location and site number for the 30 sites used in this study $\ldots \ldots \ldots \ldots \ldots$

2. Trends in steamflow, $1985-98 \ldots \ldots \ldots \ldots \ldots \ldots \ldots \ldots \ldots \ldots \ldots$

3. Trends in load for total nitrogen and total phosphorus . . . . . . . . . 10

4-5. Graphs showing:

4. Combined annual flow and loads from the three largest rivers

(Susquehanna, Potomac, and James) draining into the Chesapeake Bay Watershed for 1988-98 compared to long-term average flow (1950-98) and the average load $(1988-98) \ldots \ldots \ldots \ldots \ldots \ldots \ldots \ldots \ldots$

5. Comparison between observed monthly concentration and a flow-weighted monthly concentration of total nitrogen. . . . . . . . 12

6-7. Maps showing:

6. Trends in flow-weighted concentrations for total nitrogen and total phosphorus . . . . . . . . . . . . . . . . . . 13

7. Trends in flow-adjusted concentrations for total nitrogen and

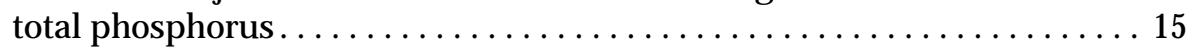

8. Boxplots showing percentage difference in statistically significant trends between the ESTIMATOR model and the Kendall-Theil test by use of absolute values . . . . 16

\section{TABLES}

Table 1. Streamflow and water-quality station numbers for the 9 River Input Program

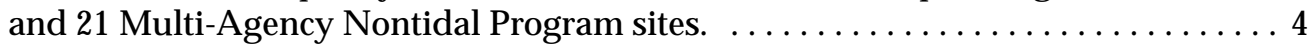

2. List of constituents in U.S. Geological Survey Chesapeake Bay nontidal water-

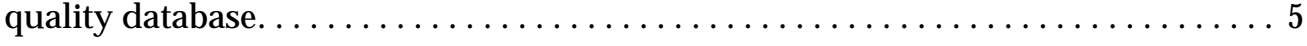




\section{Trends and Status of Flow, Nutrients, and Sediments for Selected Nontidal Sites in the Chesapeake Bay Watershed, 1985-98}

\author{
by Michael J. Langland, \\ U.S. Geological Survey, \\ Joel D. Blomquist, U.S. Geological Survey, \\ Lori A. Sprague, U.S. Geological Survey, \\ and Robert E. Edwards, Susquehanna River \\ Basin Commission
}

\begin{abstract}
Data from 30 stream sites in nontidal portions of the Chesapeake Bay Watershed were analyzed to document annual nutrient and sediment loads and trends for the period 1985 through 1998 as part of an annual water-quality update for the Chesapeake Bay Program. Annual loads were estimated by use of the U.S. Geological Survey ESTIMATOR model and are available upon request. Trends were estimated by use of either linear regression, Seasonal Kendall, or Kendall-Theil tests. Trends were reported for monthly-mean flow, monthly load, flow-adjusted concentration, and flow-weighted concentration. Mean yields and median concentrations were calculated to help assess current waterquality status and to facilitate comparisons between basins. The trend in flow was upward at 12 of the 30 sites. Trends of nutrient and sediment load were upward at these same 12 sites. Trends in flow-adjusted and flow-weighted concentrations varied by species. Trends in flow-weighted concentrations were generally upward or not significant for the nitrogen species and parallel or not significant for phosphorus species. Trends in flowadjusted concentrations were downward at nearly all sites for sediment and dissolved solids in the Susquehanna and Potomac River Basins and generally were not significant in the Virginia river basins.
\end{abstract}

\section{INTRODUCTION}

The ecosystem of the Chesapeake Bay has been adversely affected by nutrient enrichment. The Chesapeake Bay Program (CBP), a multi-jurisdictional restoration effort, established a goal to reduce controllable nutrient loads into the estuary by 40 percent by the year 2000. Results from the CBP watershed and water-quality models indicated that water quality would be sufficiently improved to support living resources if the 40-percent nutrient-reduction goal was met. Individual nutrient-reduction goals and associated strategies were established for the major rivers delivering nutrients to the Bay. Progress toward these reduction goals have been reevaluated by use of the watershed and water-quality models. Additionally, water-quality and living-resource data are compiled and analyzed to assess the response of the watershed to nutrient-reduction efforts. The 1998 data-analysis effort is part of an annual effort to document changes in water quality and living resources in response to Nutrient Reduction Strategies (NRS) in the Chesapeake Bay Watershed.

Two programs, the River Input Monitoring and Multi-Agency Nontidal Programs, provide information about water-quality conditions in the nontidal areas of the Bay. As part of the River Input Monitoring Program, water-quality and streamflow data are collected at nine stations near the Fall Line (fig. 1). Through the Multi-Agency Nontidal Program, water-quality and streamflow data are collected by several agencies at 21 sites upstream from the River Input Program sites in the nontidal watershed (fig. 1). The water-quality and streamflow data are used to determine trends in streamflow and in concentration and load of nutrients. At 15 of the 21 sites, trend calculations were completed by the U.S. Geological Survey (USGS) in cooperation with Maryland Department of Natural Resources (MdDNR), Virginia Department of Environmental Quality (VaDEQ), and Washington, D.C., Council of Governments (WashCOG); and at 6 sites by the Susquehanna River Basin Commission (SRBC) as part of the Susquehanna Nutrient Assessment Program. 


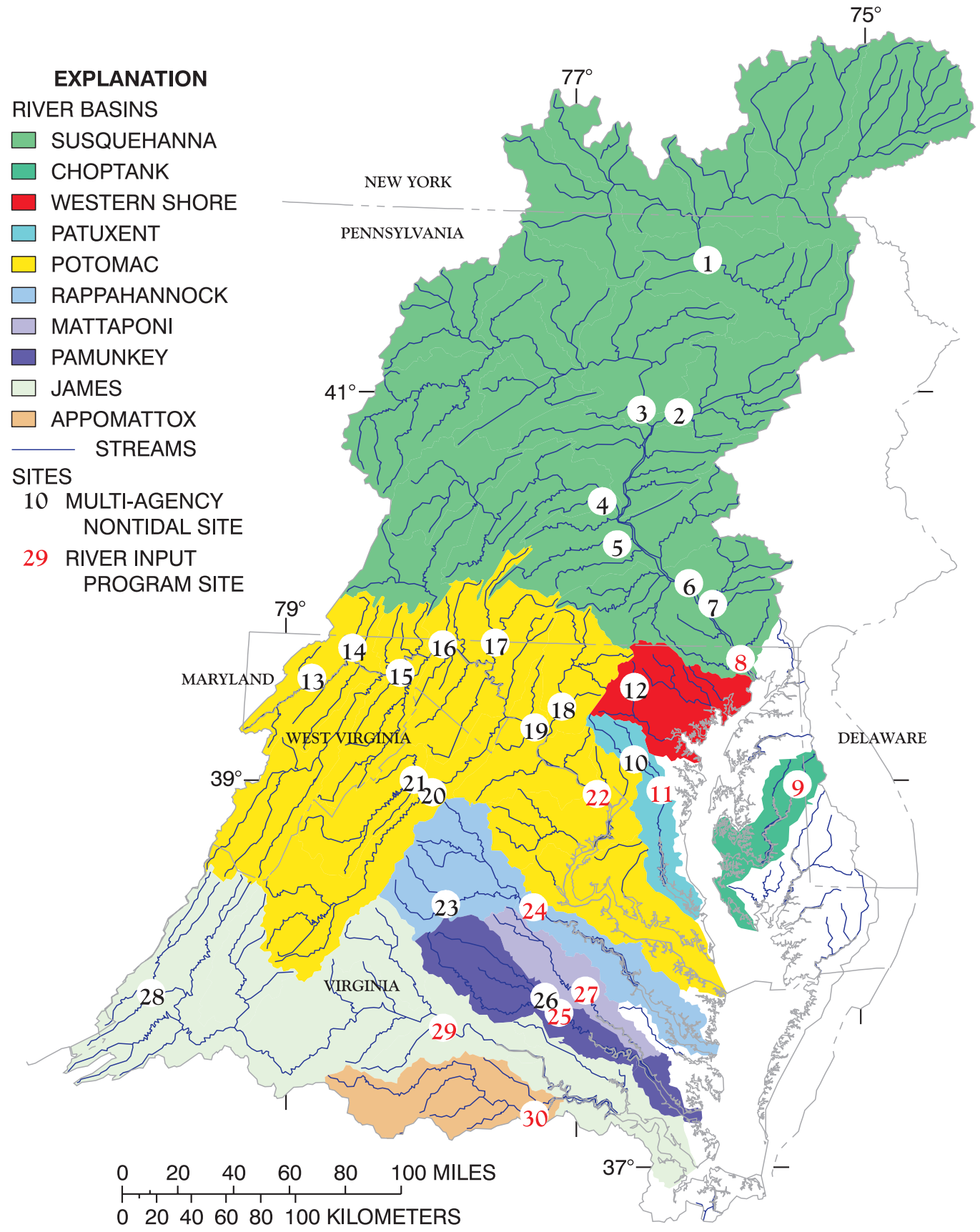

Figure 1. Location and site number for the 30 sites used in this study. 


\section{PURPOSE}

This report documents the methods used to estimate trends and status in flow and nutrient and sediment concentrations and loads and presents trends in flow and nutrient and sediment waterquality data from 1985 to 1998 from nontidal sites in the Chesapeake Bay Watershed. Water-quality and biological data from the tidal portions of the Bay will be used to assess changes in water quality in response to natural conditions and implementation of nutrient-reduction strategies.

\section{STUDY METHODS}

The methods section discusses how the data sets were constructed and describes the statistical tests used to interpret trends. Water-quality constituent loads were estimated by use of a multiparameter regression model. Trends were estimated by use of both parametric and nonparametric tests.

\section{Data Set Construction}

The following section describes the sources of the water-quality and flow data, selection of constituents, record length, and estimation of missing constituents used in calculations of annual loads and trends.

Water-quality concentration and streamflow data were retrieved and compiled from the following agencies: the USGS, the U.S. Environmental Protection Agency (USEPA), the Pennsylvania Department of Environmental Protection (PaDEP), the MdDNR, the VaDEQ, the SRBC, the Interstate Commission on the Potomac River Basin (ICPRB), and the WashCOG. This effort was undertaken to update the nontidal water-quality database to include 1997 and 1998 data at the 30 sites. This database originally consisted of data from 1972 through 1992 (Langland and others, 1995) and was updated through 1996 (Langland and others, 1998). The 30 sites analyzed as part of the 1998 Chesapeake Bay Program water-quality update are listed in table 1.

Data for a total of 38 physical, biological, and chemical water-quality constituents (table 2 ) were retrieved, if available, and updated for the 30 sites in table 1 . These constituents include 14 nutrient species, suspended sediment, and total suspended solids. Continuous daily streamflow data were retrieved from the USGS National Water Information System (NWIS) database. The updated waterquality database and the USGS streamflow data- base provided the input data files to estimate annual loads and trends. Constituent concentration data were quality assured by use of a statistical program that identified suspect remark codes (such as less than detection or greater-than values), missing dates and/or missing times associated with the sample before they were added to the database. Additionally, the raw and residual data were visually examined before their use in the various trend and load analysis programs.

The following nitrogen, phosphorus, and sediment/solids species were tested for trend and have estimated annual loads where applicable. Because of analytical differences between SED and TSS determinations, SED concentrations tend to be higher and more variable than TSS concentrations (Kammerer and others, 1998). Therefore, caution should be used when comparing the two.

\begin{tabular}{|c|c|}
\hline \multicolumn{2}{|l|}{ Nitrogen species: } \\
\hline Total nitrogen & $\mathrm{TN}$ \\
\hline Dissolved Kjeldahl nitrogen & DKN \\
\hline Total Kjeldahl nitrogen & TKN \\
\hline Total ammonia & $\mathrm{TNH}_{3}$ \\
\hline Dissolved ammonia & $\mathrm{DNH}_{3}$ \\
\hline $\begin{array}{l}\text { Total or dissolved nitrate, or total or } \\
\text { dissolved nitrite plus nitrate }\end{array}$ & NOx \\
\hline \multicolumn{2}{|l|}{ Phosphorus species: } \\
\hline Total phosphorus & TP \\
\hline Dissolved phosphorus & DP \\
\hline Dissolved inorganic phosphorus & DIP \\
\hline Suspended sediment & SED \\
\hline Total suspended solids & TSS \\
\hline
\end{tabular}

In some data sets, water-quality records were missing for some constituents. Where possible, the concentration of missing constituents was calculated from the reported species of the constituent. For example, if the concentration of total nitrogen was missing, an estimated value was obtained by adding total Kjeldahl (total organic nitrogen plus total ammonia) and total nitrite plus nitrate. If total nitrite plus nitrate was missing, the sum of the total nitrite and total nitrate was used if available. If more than one of the nitrogen species used in calculating total nitrogen was below the detection limit, the estimated value was not determined or reported as less than the combined minimum reporting limit. In some data sets, total nitrogen and total phosphorus are calculated as the sum of the particulate and dissolved constituents. The concentration of missing constituents was estimated ONLY for input data files used to calculate loads and trends. Missing values in the statistical database were not populated. 
Table 1. Streamflow and water-quality station numbers for the 9 River Input Program and 21 Multi-Agency Nontidal Program sites

\begin{tabular}{|c|c|c|c|c|c|c|}
\hline $\begin{array}{l}\text { Streamflow } \\
\text { station }\end{array}$ & $\begin{array}{l}\text { Water-quality } \\
\text { station }\end{array}$ & Latitude & Longitude & $\begin{array}{l}\text { Map } \\
\text { ID }\end{array}$ & $\begin{array}{l}\text { Drainage area } \\
\text { (square miles) }\end{array}$ & Station name \\
\hline \multicolumn{7}{|c|}{$\underline{\text { River Input Program Sites }}$} \\
\hline 01491000 & 01491000 & 385950 & 754710 & 9 & 113 & Choptank River near Greensboro, Md. \\
\hline 01578310 & 01578310 & 393928 & 761029 & 8 & 27,100 & Susquehanna River at Conowingo, Md. \\
\hline 01594440 & 01594440 & 385721 & 764136 & 11 & 348 & Patuxent River near Bowie, Md. \\
\hline 01646580 & PR01 & 385546 & 770701 & 22 & 11,600 & Potomac River at Chain Bridge, Md. \\
\hline 01668000 & 01668000 & 381920 & 773105 & 24 & 1,596 & Rappahannock River near Fredericksburg, Va. \\
\hline 01673000 & 01673000 & 374603 & 771957 & 25 & 1,081 & Pamunkey River near Hanover, Va. \\
\hline 01674500 & 01674500 & 375316 & 770948 & 27 & 601 & Mattaponi River near Beulahville, Va. \\
\hline 02035000 & 02035000 & 374015 & 780510 & 29 & 6,257 & James River at Cartersville, Va. \\
\hline 02041650 & 02041650 & 371330 & 772832 & 30 & 1,344 & Appomattox River at Matoaca, Va. \\
\hline \multicolumn{7}{|c|}{ Multi-Agency Nontidal Program Sites } \\
\hline 01531500 & 01531500 & 414555 & 762628 & 1 & 7,797 & Susquehanna River at Towanda, Pa. \\
\hline 01540500 & 01540500 & 405729 & 763710 & 2 & 11,220 & Susquehanna River at Danville, $\mathrm{Pa}$. \\
\hline 01553500 & 01553500 & 405803 & 765236 & 3 & 6,859 & West Branch Susquehanna River at Lewisburg, Pa. \\
\hline 01567000 & 01567000 & 402842 & 770746 & 4 & 3,354 & Juniata River at Newport, Pa. \\
\hline 01570000 & 01570000 & 401508 & 770117 & 5 & 470 & Conodoguinet Creek near Hogestown, Pa. \\
\hline 01576000 & 01576000 & 400316 & 763152 & 6 & 25,990 & Susquehanna River at Marietta, $\mathrm{Pa}$. \\
\hline 01576754 & 01576754 & 395647 & 762205 & 7 & 470 & Conestoga River at Conestoga, $\mathrm{Pa}$. \\
\hline 01586000 & NPA0165 & 393000 & 765300 & 12 & 56.6 & North Branch Patapsco River at Cederhurst, Md. \\
\hline 01592500 & PXT0809 & 390700 & 765231 & 10 & 132 & Patuxent River at Laurel, Md. \\
\hline 01599000 & GEO0009 & 392936 & 790242 & 13 & 47 & Georges Creek near Franklin, Md. \\
\hline 01601500 & WIL0013 & 393941 & 784650 & 14 & 247 & Wills Creek near Cumberland, Md. \\
\hline 01610000 & РОТ2766 & 393218 & 782717 & 15 & 3,109 & Potomac River at Paw Paw, W. Va. \\
\hline 01613000 & РОT2386 & 394149 & 781036 & 16 & 4,073 & Potomac River at Hancock, Md. \\
\hline 01614500 & CON0180 & 394256 & 774931 & 17 & 501 & Conococheague Creek at Fairview, Md. \\
\hline 01643000 & MON0155 & 392313 & 772158 & 18 & 817 & Monocacy River at Reels Mill Road, Md. \\
\hline 01638500 & POT1595 & 391624 & 773238 & 19 & 9,651 & Potomac River at Point of Rocks, Md. \\
\hline 01631000 & 1BSSF003.56 & 385449 & 781240 & 20 & 1,642 & South Fork Shenandoah River at Front Royal, Va. \\
\hline 01634000 & 1BNFS010.34 & 385836 & 782011 & 21 & 768 & North Fork Shenandoah River near Strasburg, Va. \\
\hline 01666500 & 3-ROB001.90 & 381930 & 780545 & 23 & 179 & Robinson River near Locust Dale, Va. \\
\hline 01671020 & 8-NAR005.42 & 375100 & 772541 & 26 & 463 & North Anna River at Hart Corner near Doswell, Va. \\
\hline 02013100 & 2-JKS023.61 & 374719 & 800003 & 28 & 614 & Jackson River below Dunlap Creek at Covington, Va. \\
\hline
\end{tabular}


Table 2. List of constituents in U.S. Geological Survey Chesapeake Bay nontidal water-quality database

$\left[\mathrm{ft}^{3} / \mathrm{s}\right.$, cubic feet per second; $\mathrm{mg} / \mathrm{L}$, milligrams per liter; $\mu \mathrm{g} / \mathrm{L}$, micrograms per liter; $\mathrm{N}$, nitrogen; $\mathrm{P}$, phosphorus; $\mathrm{C}$, carbon; $\mathrm{CaCO}_{3}$, calcium carbonate; $\mathrm{g} / \mathrm{m}^{2}$, grams per square meter]

\begin{tabular}{|c|c|c|c|}
\hline $\begin{array}{l}\text { Constituent } \\
\text { code }\end{array}$ & Data description & $\begin{array}{l}\text { Constituent } \\
\text { code }\end{array}$ & Data description \\
\hline STAID & Station number & 00618 & Dissolved nitrate as $\mathrm{N}$, in $\mathrm{mg} / \mathrm{L}$ \\
\hline SNAME & Station name & 00620 & Total nitrate as $\mathrm{N}$, in $\mathrm{mg} / \mathrm{L}$ \\
\hline AGENCY & Collection agency code & 00623 & Dissolved ammonia plus organic nitrogen as $\mathrm{N}$, in $\mathrm{mg} / \mathrm{L}$ \\
\hline DATE & Date of sample collection & 00625 & Total ammonia plus organic nitrogen as $\mathrm{N}$, in $\mathrm{mg} / \mathrm{L}$ \\
\hline TIME & Time of sample collection & 00630 & Total nitrate plus nitrite as $\mathrm{N}$, in $\mathrm{mg} / \mathrm{L}$ \\
\hline LAT & Latitude & 00631 & Dissolved nitrate plus nitrite as $\mathrm{N}$, in $\mathrm{mg} / \mathrm{L}$ \\
\hline LONG & Longitude & 00665 & Total phosphorus as $\mathrm{P}$, in $\mathrm{mg} / \mathrm{L}$ \\
\hline HUC & Hydrologic unit code & 00671 & Dissolved inorganic phosphorus as $\mathrm{P}$, in $\mathrm{mg} / \mathrm{L}$ \\
\hline 00010 & Water temperature, in degrees Celsius & 00680 & Total organic carbon as $\mathrm{C}$, in $\mathrm{mg} / \mathrm{L}$ \\
\hline 00060 & Daily mean discharge, in $\mathrm{ft}^{3} / \mathrm{s}$ & 00681 & Dissolved organic carbon as $\mathrm{C}$, in $\mathrm{mg} / \mathrm{L}$ \\
\hline 00061 & Instantaneous discharge, in $\mathrm{ft}^{3} / \mathrm{s}$ & 00900 & Hardness as $\mathrm{CaCO}_{3}$, in $\mathrm{mg} / \mathrm{L}$ \\
\hline 00065 & Stream stage, in feet & 00915 & Dissolved calcium as $\mathrm{Ca}$, in $\mathrm{mg} / \mathrm{L}$ \\
\hline 00076 & Turbidity, in NTU & 00925 & Dissolved magnesium as $\mathrm{Mg}$, in $\mathrm{mg} / \mathrm{L}$ \\
\hline 00095 & Specific conductance, in microsiemens per centimeter & 00930 & Dissolved sodium as $\mathrm{Na}$, in $\mathrm{mg} / \mathrm{L}$ \\
\hline 00300 & Dissolved oxygen, in mg/L & 00935 & Dissolved potassium as $\mathrm{K}$, in $\mathrm{mg} / \mathrm{L}$ \\
\hline 00400 & $\mathrm{pH}$, in $\mathrm{pH}$ units & 00940 & Dissolved chlorine as $\mathrm{Cl}$, in $\mathrm{mg} / \mathrm{L}$ \\
\hline 00410 & Total alkalinity as $\mathrm{CaCO}_{3}$, in $\mathrm{mg} / \mathrm{L}$ & 00945 & Dissolved sulfate as $\mathrm{SO}_{4}$, in $\mathrm{mg} / \mathrm{L}$ \\
\hline 00530 & Total suspended solids at 105 degrees Celsius, in mg/L & 00955 & Dissolved silica as $\mathrm{SiO}_{2}$, in mg/L \\
\hline 00600 & Total nitrogen as $\mathrm{N}$, in $\mathrm{mg} / \mathrm{L}$ & 32211 & Chlorophyll $a$, in $\mu \mathrm{g} / \mathrm{L}$ \\
\hline 00608 & Dissolved ammonia as $\mathrm{N}$, in $\mathrm{mg} / \mathrm{L}$ & 32231 & Chlorophyll $b$, in $\mu \mathrm{g} / \mathrm{L}$ \\
\hline 00610 & Total ammonia as $\mathrm{N}$, in $\mathrm{mg} / \mathrm{L}$ & 32232 & Chlorophyll $c$, in $\mu \mathrm{g} / \mathrm{L}$ \\
\hline 00613 & Dissolved nitrite as $\mathrm{N}$, in $\mathrm{mg} / \mathrm{L}$ & 49954 & Periphyton algal dry mass, in $\mathrm{g} / \mathrm{m}^{2}$ \\
\hline 00615 & Total nitrite as $\mathrm{N}$, in $\mathrm{mg} / \mathrm{L}$ & 80154 & Total suspended sediment, in $\mathrm{mg} / \mathrm{L}$ \\
\hline
\end{tabular}


For trend results to be most useful for the 1998 water-quality update, the time series would ideally begin in January 1985 and end in December 1998. Shorter time-series data are acceptable, however, if they meet certain criteria. For both the ESTIMATOR model and any trend test, the data set must contain a minimum of 10 years and 100 "monthly" samples, or a mixture of monthly and quarterly data with at least 10 years and 75 samples with no date gaps greater than 3 months. Loads and trends were estimated on data sets for any time periods of 10 years or greater starting between January 1985 and January 1989 and continuing through December 1998.

\section{Data Analysis}

A brief description of the model used to estimate loads (ESTIMATOR), the statistical tests used to compute trends (linear regression, Seasonal Kendall, and Kendall-Theil), and procedures used with censored data are presented below.

\section{ESTIMATOR Model}

The loads of nutrients, suspended sediment, and total solids were estimated by use of the USGS 7-para-meter, log-linear regression model (ESTIMATOR) developed by Cohn and others (1989). The model uses the Minimum Variance Unbiased Estimator (MVUE) developed by Bradu and Mundlak (1970) to correct for retransformation bias associated with log-linear regression. The adjusted maximum likelihood estimator (AMLE) (Cohn, 1988) is used to assign concentrations to censored data, which are data below a detectable limit. The model is of the form:

$$
\begin{aligned}
& \operatorname{In}[C]=\beta_{o}+\beta_{1} \ln [Q / \bar{Q}]+\beta_{2}\{\ln [Q / \bar{Q}]\}^{2} \\
& +\beta_{3}[T-\bar{T}]+\beta_{4}[T-\bar{T}]^{2} \\
& +\beta_{5} \sin [2 \pi T]+\beta_{6} \cos [2 \pi T]+\varepsilon
\end{aligned}
$$

where $I n$ is the natural logarithm function;

$C$ is measured concentration, in milligrams per liter;

$Q$ is measured streamflow, in cubic feet per second;

$T$ is time, measured in decimal years;

$\bar{Q}$ and $\bar{T}$ are centering variables for streamflow and time; $\beta_{x}$ are parameters estimated by ordinary least squares (non-censored data) and minimum variance (censored data); and

$\beta_{0}$ is a constant;

$\beta_{1}$ and $\beta_{2}$ describe the relation between concentration and flow;

$\beta_{3}$ and $\beta_{4}$ describe the trend in concentration data;

$\beta_{5}$ and $\beta_{6}$ describe seasonal variation in concentration data; and

$\varepsilon$ is combined independent random error, assumed to be normally distributed with zero mean and variance $\sigma_{\varepsilon}^{2}$.

\section{Linear Regression}

Linear regression is a parametric test that approximates the relation between two continuous variables. A linear trend is estimated by regressing a response variable (for example, flow or load) as a function of an explanatory variable (such as time). It is important that residual plots meet the assumptions of normality, constant variance, linearity, and independence. In most cases, data must be logtransformed in order to improve linearity. If this transformation is used, the residual plots again must be checked for normality, constant variance, linearity, and independence. When the assumptions are met, a null hypothesis of zero slope over time is tested. If the slope is significantly greater than zero, the null hypothesis is rejected, and the conclusion is that a linear trend over time has occurred. Because the regression model does not account for the error and dependence in the estimates, a conservative $p$-value of 0.01 or less was considered significant. The magnitude (percentage change over time) was estimated from the equation $\left[\mathrm{e}^{\left(\mathrm{b}^{*} \mathrm{t}\right)}-1\right]{ }^{*} 100$ where $\mathrm{b}$ is the slope and $\mathrm{t}$ is the time, in years. The upper and lower bounds, representing the 95-percent confidence interval around the magnitude, also were calculated. Helsel and Hirsch (1992) provide additional discussion for applying regression techniques to surface-water data.

\section{Seasonal Kendall Test}

The Seasonal Kendall (SK) test (Hirsch and others, 1982) is a nonparametric test for a monotonic linear trend that is resistant to outliers and is not dependent on the normality of the data set. By comparing only the data from similar seasons (monthly data used in the study), the test also reduces seasonal effects on concentrations when testing for trend. If the later value in time is larger, then a plus is recorded; if the later value in time is 
smaller, then a minus is recorded. The test statistic is computed as the difference between the total number of pluses (increases in time) and the number of minuses (decreases in time). If the test statistic is 0 , then there is no change (no trend) in time. As the test statistic increases or decreases from 0 , the probability of a seasonal trend also increases. A $\mathrm{p}$-value of 0.05 or less was considered significant.

\section{Kendall-Theil Trend Analysis}

The Kendall-Theil (KT) analysis is also a nonparametric test for a monotonic linear trend by use of pairwise comparison and a Kendall's tau test for significance, similar to the SK test. The KT analysis differs from the SK test, however, in how it adjusts for seasonality. The SK test accounts for seasonality by calculating pairwise slopes on data within the same season; the overall trend slope is computed from the median of these seasonal slopes. The KT analysis accounts for seasonality by first obtaining residuals from an MVUE regression that includes seasonality terms. The trend slope is then determined by calculating pairwise slopes on the residual data for the entire period of study and computing the overall median of these slopes (Helsel and Hirsch, 1992). This approach allows increased power in the slope estimate for the KT test over the SK test. Flow-adjusted and seasonadjusted residuals from the ESTIMATOR model (with date terms $B_{3}$ and $B_{4}$ removed) were used as input to the KT analysis to estimate an adjusted trend in concentration. For censored data, a range in slope and magnitude was defined by twice computing the median slope-first, with censored data equal to zero, and second, with censored data equal to the maximum detection limit (Helsel and Hirsch, 1992). The magnitude was computed from the formula [bn/C-(bn/2)], where $b$ is the slope, $n$ is the number of data points, and $C$ is the intercept (predicted concentration at center of flow) (Cohn and others, 1989). The upper and lower error bounds were calculated from the ranked slopes that correspond to the 95-percent confidence level. A p-value of 0.05 or less was considered significant.

\section{Detection and Trend Reporting of Censored Data}

The presence of a large number of censored values (values reported below the detection limit) in a data set can adversely affect the estimation of load and trend slope by not allowing for corrections because of variations in streamflow. In the ESTIMATOR model, values were assigned to the censored data by use of the AMLE (Cohn and others, 1989).

The following decisions were presented to the Data Analysis Work Group (DAWG), a workgroup of the Monitoring Subcommittee of the Chesapeake Bay Program, and approved for use with the tests for trend. These decisions are based on current USGS computer program analysis (Shertz and others, 1991) and work by Helsel and Hirsch (1992).

- $<5$ percent censored data - censored values will be assigned one half of the detection limit. For all trend tests, the p-value, the slope estimate, and the magnitude (percentage change over time) will be reported.

- Between 5 and 20 percent censored data - three separate trend analysis tests of the data will be performed. First, on the raw data file with censored data set to half the detection limit (both KT and SK); second, all censored data set to 0 (KT only); and third, all censored data set to the detection limit (KT only). In these instances, the highest $\mathrm{p}$-value, the range in slope estimate, and a range in the magnitude of the trend will be reported.

- >20 percent censored data - trend results will not be reported. 


\section{TRENDS IN FLOW AND WATER-QUALITY CONDITIONS}

Trends in water quality were estimated by use of parametric and nonparametric statistical tests described earlier in this report. The parametric test involved a regression of nontransformed and transformed data with time. Nonparametric tests used nontransformed data and included the SK and KT. The SK test was used to estimate trends in streamflow and loads and was used to compare with linear regression trends. Analysis for trend was performed on the following:

- monthly-mean flow

- monthly load

- flow-weighted concentrations (FWC), and

- flow-adjusted concentrations (FAC)

Each of the above trends provide a unique perspective on the changes in water quality within the Chesapeake Bay Watershed. These trends can be used to help document water-quality changes as a result of both natural and human-induced influences and can be used as indicators of improvement or lack of improvement of that quality within the Bay Watershed.

\section{Monthly-Mean Streamflow}

Trends in monthly-mean flows indicate the changes in hydrology (streamflow) over time. Fluctuations in streamflow affect the observed concentrations of nutrients and the average loads and concentrations of these constituents delivered to the tidal estuaries. Changes in streamflow also affect water quality and living-resource responses in the estuary. The trend in flow was calculated by use of a regression (log flow) with time. Trends were reported only for those sites where the residuals of the model met the assumptions of normality, constant variance, linearity, and independence.

Significant upward trends in streamflow (fig. 2 and Appendix 1) occurred at 12 sites. The sites are concentrated in the middle and lower areas of the Potomac River Basin, where significant flooding occurred in 3 of the last 4 years. None of the 30 sites in the basin showed a downward trend in streamflow. For comparison, the SK test (monthly) also was performed at all sites, and where trends were significant by use of the SK, trends also were significant by use of the regression model. However, because parametric tests tend to have more power to detect trends than do nonparametric tests, some sites had not-significant trends by use of SK where the parametric test indicated a significant trend. In no cases did the results indicate trends in opposing directions.

\section{Monthly Load}

The constituent load is highly related to and dependent on flow. The load represents the amount of a given constituent transported and delivered downstream, eventually reaching the tidal estuaries. A trend in load will aid in explaining water-quality and living-resource changes in the tidal estuaries and assessing the effectiveness of Nutrient Reduction Strategies. Linear regression of log-transformed monthly loads from ESTIMATOR as a function of time was used to test for trend. In most cases, the regression produced normally distributed residuals.

For nearly all constituents, load increased with flow. Where flow increased significantly, significant upward trends in TN load occurred at 6 of the 12 sites (fig. 3) and NOx load trends were upward at 7 of the 12 sites (Appendix 1). The only downward trends in TN and NOx loads occurred at the Patuxent River Input site (site 11 on fig. 1). Significant upward trends in TP load occurred at 4 of the 12 sites having upward trends in flow and, similar to the nitrogen, a downward trend in TP load occurred at the Patuxent River Input site (fig. 3). Results for DP loads, however, indicate downward trends at seven of the eight Susquehanna River sites (Appendix 1). In general, loads for TN and TP entering the Bay from the River Input Monitoring sites have increased from 1985 to 1998.

In an average flow year, the three largest rivers draining to the Bay (the Susquehanna, the Potomac, and the James) deliver about 87 percent of the streamflow and about 96 percent of the nitrogen, 91 percent of the phosphorus, and 93 percent of the suspended sediment or total solids loads into the Chesapeake Bay (Langland and others, 1995). During the period of study, flow for 3 of the last 4 years has exceeded the long-term average flow at the three largest rivers (fig. 4).

\section{Flow-Weighted Concentrations}

A trend in monthly flow-weighted concentrations represents a trend that is NOT adjusted for the effects of streamflow. This approach can be useful in comparing trends from nontidal sites to sites in the tidal tributaries and mainstem of the Bay. Monthly flow-weighted concentrations are calcu- 


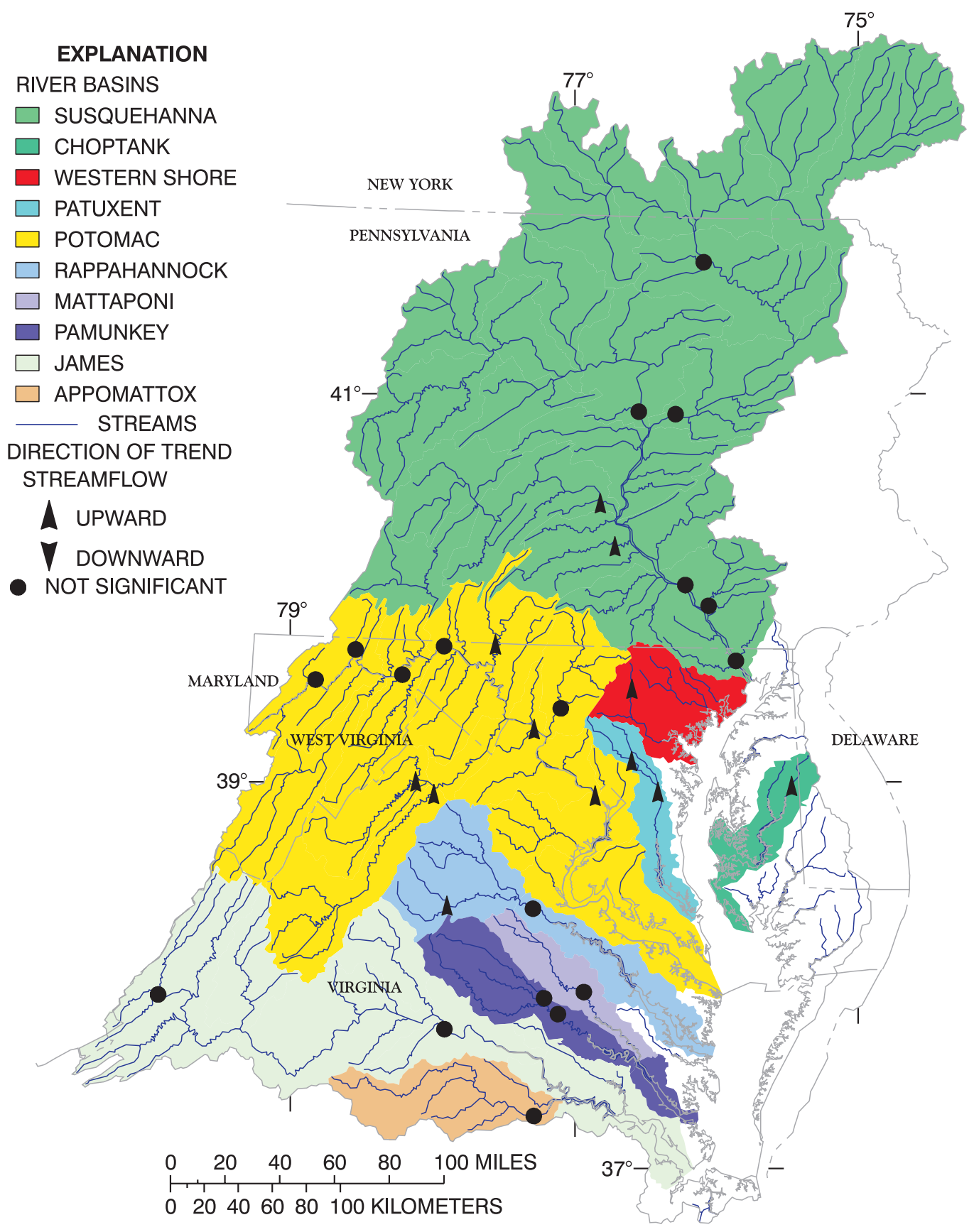

Figure 2. Trends in streamflow, 1985-98. 


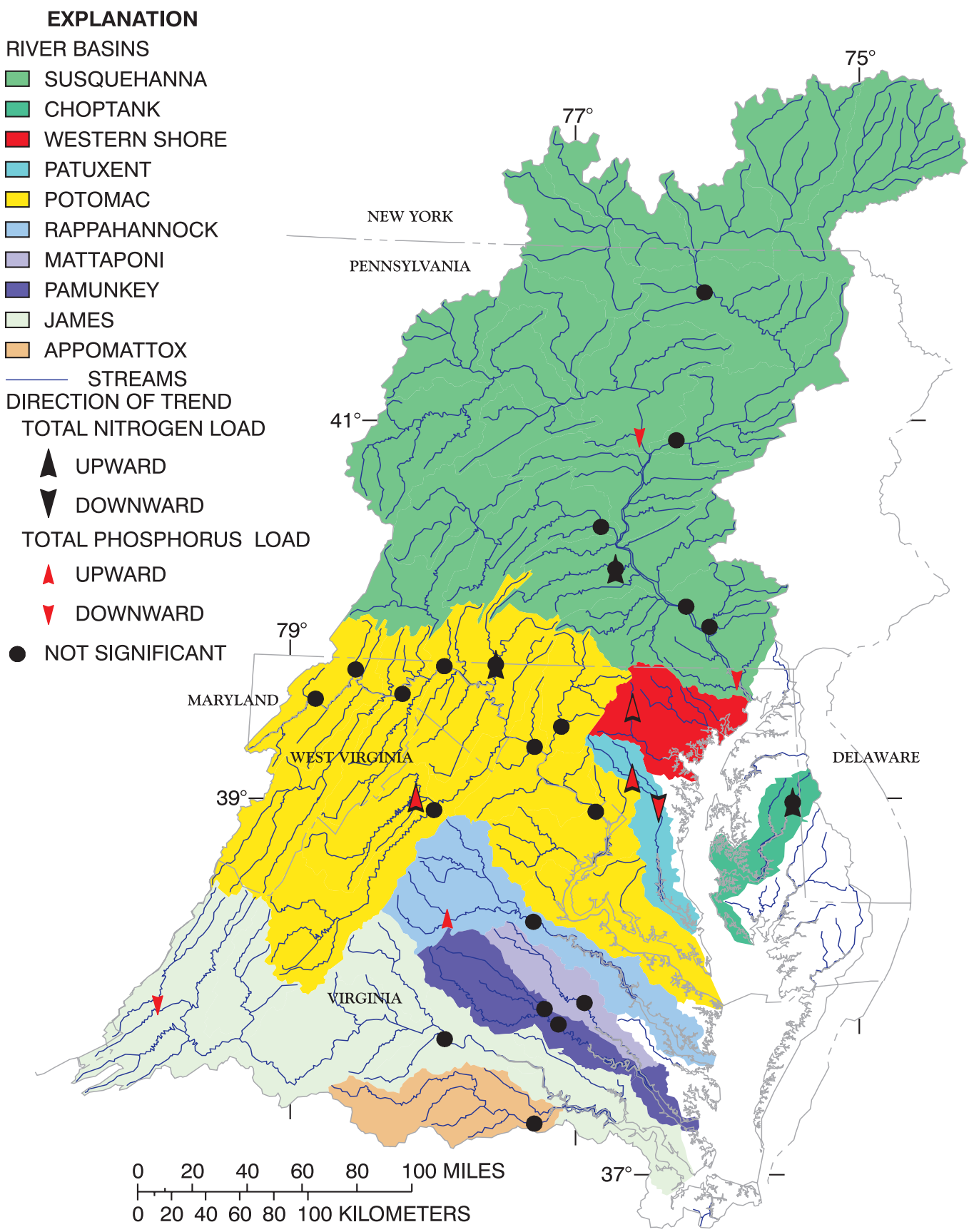

Figure 3. Trends in load for total nitrogen and total phosphorus. 

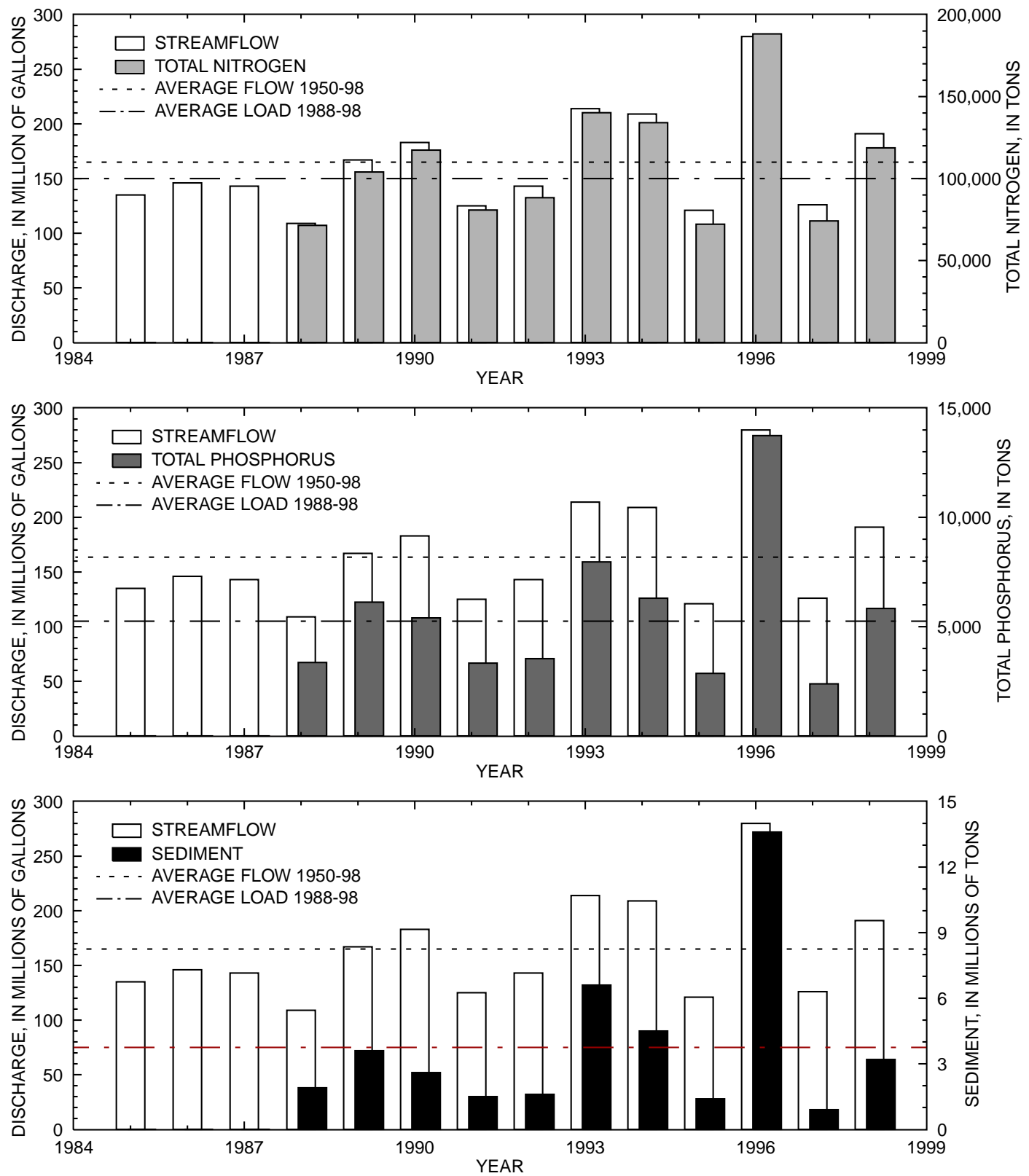

Figure 4. Combined annual flow and loads from the three largest rivers (Susquehanna, Potomac, and James) draining into the Chesapeake Bay Watershed for 1988-98 compared to long-term average flow (1950-98) and the average load (1988-98). 
lated by dividing the total monthly load (from ESTIMATOR) by the monthly streamflow. Because ESTIMATOR uses the daily streamflow record, a daily concentration can be estimated and summed between sampling dates, and used to represent a "flow-weighted" monthly concentration, which may be more representative of the true monthly mean concentration. For example, in figure 5, the observed concentration of total nitrogen is $1.0 \mathrm{mg} / \mathrm{L}$, not weighted for flow. This is based on the one sample collected per month. When weighted for streamflow, however, the concentration (from ESTIMATOR) increases to $2.2 \mathrm{mg} / \mathrm{L}$. It is important to account for the flow variability because the volume of flow occurring in short periods between sample intervals is likely to have a more pronounced and long-lived effect on average concentrations in the tidal estuaries and other mixed receiving areas. Therefore, a flow-weighted concentration should provide a more accurate estimate of the monthly mean concentration and may correlate better with trends in estuarine concentrations. Monthly flow-weighted concentrations were tested for trend by use of linear regressions. In most cases, the regression produced normally distributed residuals. In some cases, the trend was significant, with non-normal residuals. This precludes the use of linear regression. In these cases, the KT test was used ("Test" column in Appendix 2).

Trends for flow-weighted TN concentrations were downward at 13 sites distributed in nearly all 10 major drainage basins (fig. 6 and Appendix 2). Trends for flow-weighted NOx concentrations were downward at five sites and were upward at six sites (Appendix 2). At only one of the six NOx sites with upward trends was the TN trend also upward. Trends in flow-weighted TP concentrations were downward at 16 sites (fig. 6). Data for one site, on the North Fork Shenandoah River, indicated an upward trend in TP. For TSS or SED, trends were upward at only two sites, one in the Patuxent River Basin, the other in the Potomac River Basin (Appendix 2).

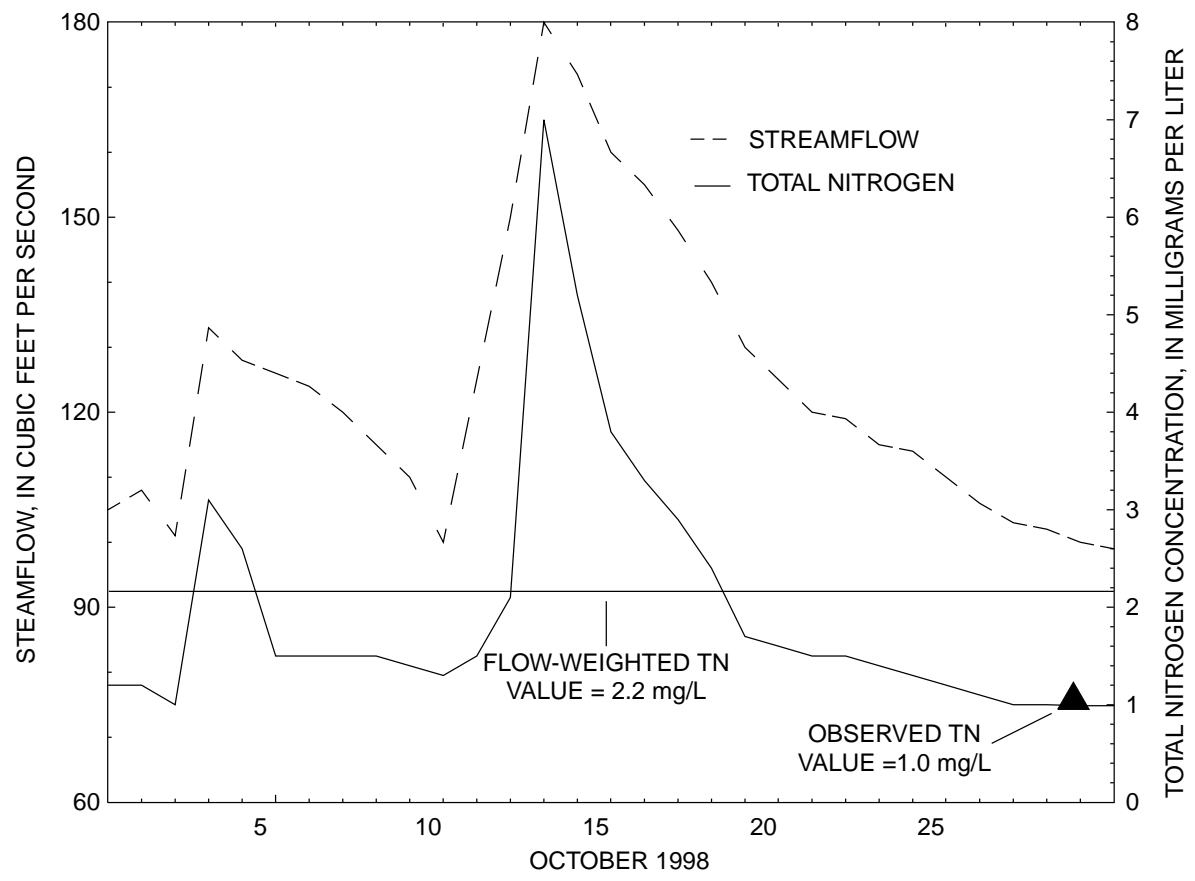

Figure 5. Comparison between observed monthly concentration and a flow-weighted monthly concentration of total nitrogen. 


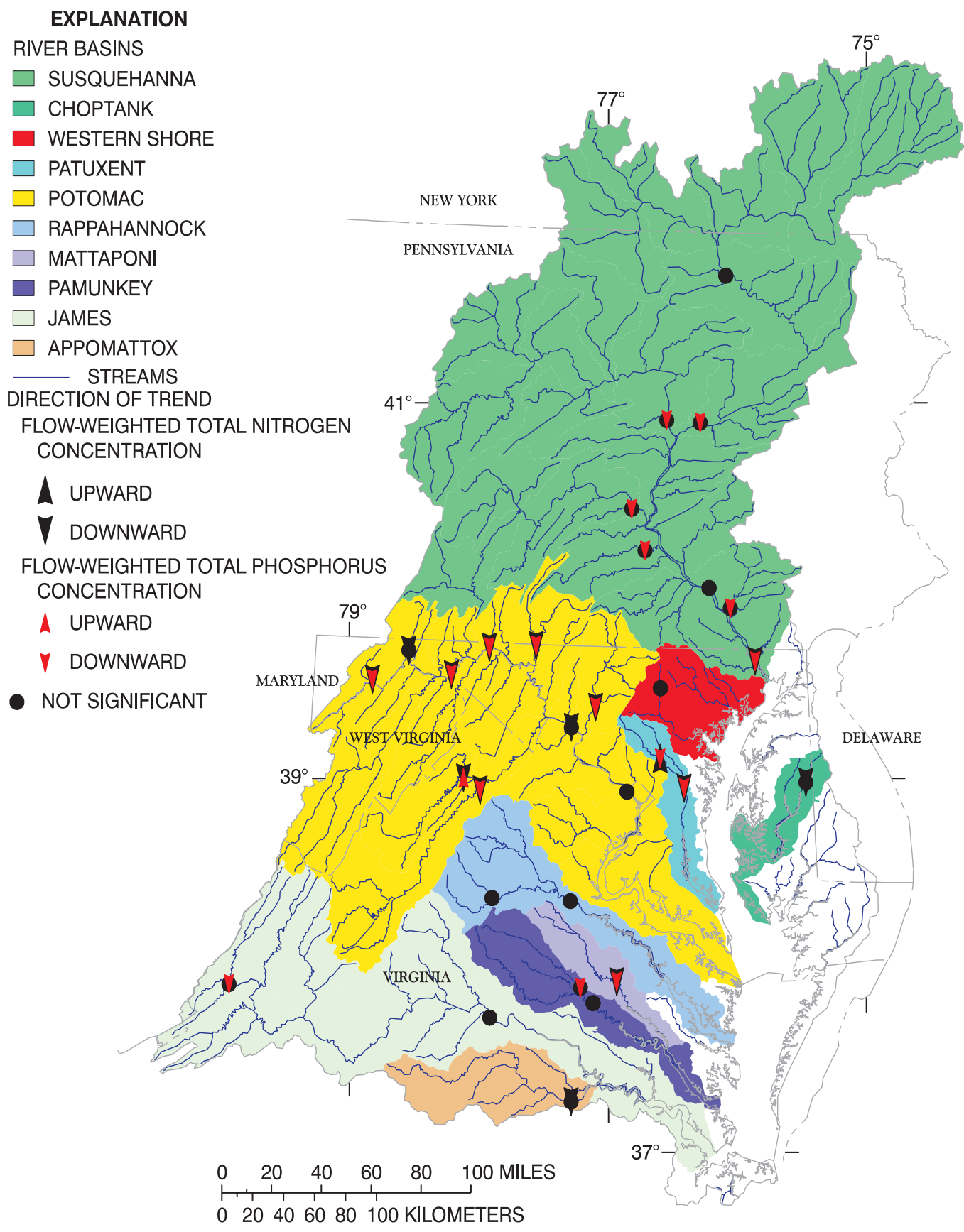

Figure 6. Trends in flow-weighted concentrations for total nitrogen and total phosphorus. 


\section{Flow-Adjusted Concentrations}

Concentrations of water-quality constituents are commonly correlated with streamflow. The cause of this relation varies between the constituent and the individual basin. For example, in point-source dominated basins, the input of many constituents is relatively constant. Increases in basin streamflow will most likely result in decreasing concentrations of these constituents as a result of dilution. In contrast, in nonpoint-source dominated basins, constituent concentrations entering the stream from overland flow will most likely increase as streamflow increases (Shertz and others, 1991). This flow-related variability must be removed to obtain flow independent water-quality concentrations that allow for examination of changes in water quality resulting from human activities. Flow-adjusted trends are the best indicator of human-induced changes affecting water quality within a watershed. To determine the trend in flow-adjusted concentration, observed concentration data were adjusted for season and streamflow by use of a 5-parameter ESTIMATOR model. This model is identical to the 7-parameter load model except the date and date-squared terms are removed. Values for multiple samples collected on the same day were averaged, and the resulting residual data set was input into the KT test.

Results from the KT test indicate trends in TN and NOx concentration adjusted for flow were downward at 19 and 12 of the 30 sites, respectively, occurring in nearly all major Chesapeake Bay drainage basins (fig. 7 and Appendix 3). While only two sites had upward trends in TN, seven sites had upward trends in NOx. Trends in flowadjusted TP concentrations were downward at 21 of the sites, with only 1 site showing an increase. The only significant upward trend for TSS or SED was in the Patuxent River Basin; trends were downward at five sites in Maryland and Virginia. As a result of flow and adjustment, an additional five TN and six TP sites indicated significant trends in concentration.

In investigations from previous years (Langland and others, 1998), trends in flow-adjusted concentration were estimated by use of the date coefficient from the 7-parameter ESTIMATOR model. This method has been questioned because of perceived log-transformation bias. As a result of testing and comparing to other methods, the ESTIMATOR does appear to be valid for quantifying trends (although trend results from ESTIMATOR were not used in this report). The percentage differences between statistically significant trend magnitudes by use of the ESTIMATOR and KT are shown in figure 8 . The median difference (absolute values) is about 7 percent for TN, 21 percent for NOx, 20 percent for TP, 12 percent for DP, and 25 percent for SED/TSS. A total of 126 trend results were compared; 114 agreed in both significance and direction. There were no cases of opposing significant trends.

\section{STATUS OF FLOW AND WATER-QUALITY CONDITIONS}

Status is a measure of current water-quality conditions. In order to help facilitate comparison of current water-quality conditions among basins in the Chesapeake Bay Watershed, a mean annual yield (based on annual loads from ESTIMATOR divided by the drainage area) and a median flowweighted concentration were calculated at each of the 30 stations presented in this report.

\section{Mean Yield}

The "status" of current yields was assessed by station and constituent at the 30 sites in this study. As requested by DAWG, this "status" assessment was based on a 3-year mean of annual yield for the years 1996, 1997, and 1998 (if not available, then the last 3 years of record) and was determined as follows:

1. Compile the 3-year yield data by station and constituent,

2. Determine the $5^{\text {th }}$ - and $95^{\text {th }}$-percentile for each constituent by use of available data from the 30 sites,

3. Subtract the $95^{\text {th }}$-percentile value from each status yield for each constituent,

4. Subtract the $5^{\text {th }}$ - and $95^{\text {th }}$-percentile values for each constituent, and

5. Divide the result from (3) by the result from (4) and multiply by 100 .

The above procedure transforms the status yields of each constituent at the 30 sites into percentages between 0 and 100 . The percentages were subtracted from 100 to allow a simple comparison between basins, because the lower the percentage, the lower the yield. Status yields and percentage for the 30 sites are presented in Appendix 1. As previously reported (Langland, 1995), the areas 


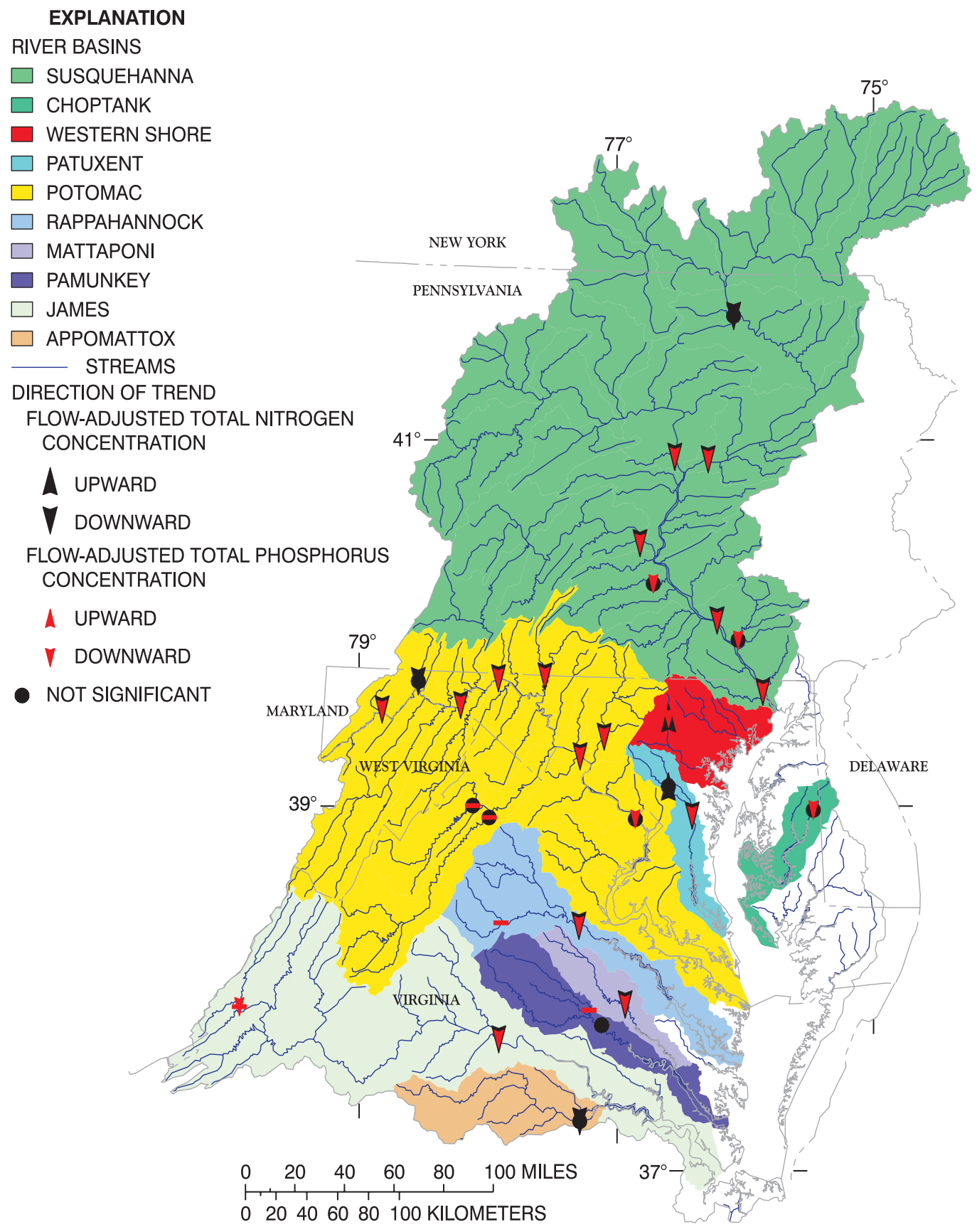

Figure 7. Trends in flow-adjusted concentrations for total nitrogen and total phosphorus. 


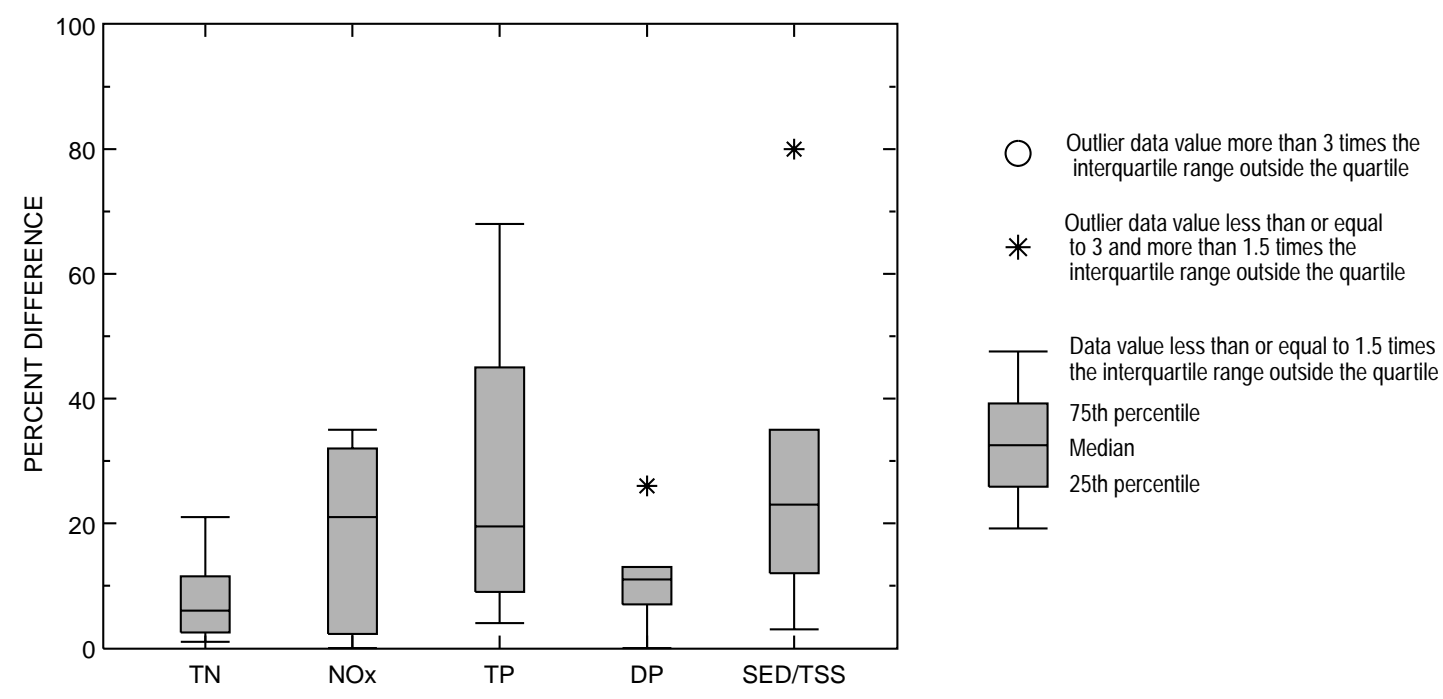

Figure 8. Percentage difference in statistically significant trends between the ESTIMATOR model and the Kendall-Theil test by use of absolute values.

with the highest nitrogen yields also contain higher percentages of land in agriculture with some association to carbonate rock type; lower yields coincide with higher percentages of forest land.

\section{Median Concentration}

The "status" of current water-quality concentrations was determined by station and constituent at the 30 sites. This status was based on the median concentration for the period 1996-98 or the last 3 years of record. The same procedure discussed above for status yields was used to compare median concentration. The status of the concentrations and percentages for the 30 sites are presented in Appendixes 2 and 3. Similar to the yields, the areas having the highest nitrogen concentrations also have higher percentages of land in agriculture; lower concentrations coincide with higher percentages of forest land.

\section{SUMMARY}

Nutrient and sediment data from 30 stream sites in nontidal portions of the Chesapeake Bay Watershed were analyzed to document annual loads and trends for the period 1985 through 1998, as part of an annual water-quality assessment for the Chesapeake Bay Program. Annual loads were estimated by use of the USGS ESTIMATOR model. Trends were estimated by use of log-transformed regressions, the Seasonal Kendall, or Kendall-Theil tests. Trends were reported for monthly-mean flow, monthly load, flow-weighted concentration, and flow-adjusted concentration. Mean yields and median flow-weighted concentrations based on the last 3 years of record were calculated to determine the status of recent water-quality conditions and help facilitate comparisons between basins. A significant upward trend in flow occurred at 12 of the 30 sites. Increases in some nutrient and sediment loads and trends occurred at these same 12 sites. Throughout the Bay watershed, trends in flowadjusted and flow-weighted concentrations were generally downward or not significant for total nitrogen, not significant for nitrite plus nitrate nitrogen, and downward or not significant for phosphorus species. Flow-adjusted trends in concentration were downward at nearly all sites for sediment and dissolved solids in the Susquehanna and Potomac River Basins and were generally not significant in the Virginia river basins. 


\section{REFERENCES CITED}

Bradu, D., and Mundlak, Y., 1970, Estimation in log-normal linear models: Journal of the American Statistical Association, v. 65, no. 329, p. 198-211.

Cohn, T.A., 1988, Adjusted maximum likelihood estimation of the moments of lognormal populations from type 1 censored samples: U.S. Geological Survey Open-File Report 88350, $34 \mathrm{p}$.

Cohn, T.A., DeLong, L.L., Gilroy, E.J., Hirsch, R.M., and Wells, R.M., 1989, Estimating constituent loads: Water Resources Research, v. 25, no. 5, p. 937-942.

Helsel, D.R., and Hirsch, R.M., 1992, Statistical methods in water resources: Amsterdam, Netherlands, Elsevier Science Publishers, Studies in Environmental Science, v. 49, 1992, $522 \mathrm{p}$.

Hirsch, R.M., Slack, J.R., and Smith, R.A., 1982, Techniques of trend analysis for monthly water-quality data: Water Resources Research, v. 18, no. 1, p. 107-121.

Kammerer, P.A., Garn, H.S., Rasmussen, P.W., and Ball, J.R., 1998, A comparison of water-quality sample collection methods used by the U.S.
Geological Survey and the Wisconsin Department of Natural Resources in Proceedings of the National Water-Quality Monitoring Council, National Conference on Monitoring, July 7-9, 1998, Reno, Nev.:

Washington, D.C., U.S. Environmental Protection Agency, p. III-259-269.

Langland, M.J., Lietman, P.L., and Hoffman, S.A., 1995, A synthesis of nutrient and sediment data from watersheds within the Chesapeake Bay drainage basin: U.S. Geological Survey Water-Resources Investigations Report 954233, $127 \mathrm{p}$.

Langland, M.J., Edwards, R.E., and Darrell, L.C., 1998, Status yields and trends of nutrient and sediment and methods of analysis for the nontidal data-collection programs, Chesapeake Bay Watershed 1985-96: U.S. Geological Survey Water-Resources Investigations Report 98-17, $60 \mathrm{p}$.

Schertz, T.L., Alexander, R.B., and Ohe, D.J., 1991, The Computer Program Estimate Trend (ESTREND), A system for the detection of trends in water-quality data: U.S. Geological Survey Water-Resources Investigations Report 91-4040, 63 p. 


\section{APPENDIX 1-TRENDS IN STREAMFLOW AND LOAD DATA FOR 9 RIVER INPUT MONITORING PROGRAM SITES AND 21 Multi-Agency Nontidal Program sites in the Chesapeake Bay Watershed}

Parameters: Q, streamflow; TN, total nitrogen; $\mathrm{DNH}$, dissolved ammonia; $\mathrm{TNH}$, total ammonia; NOx, total or dissolved nitrate, or, nitrite plus nitrate; DKN, dissolved ammonia plus organic nitrogen; TKN, total ammonia plus organic nitrogen; TP, total phosphorus; DP, dissolved phosphorus; DIP, dissolved inorganic phosphorus; TSS, total suspended solids; SED, suspended sediment.

Station: flow, USGS streamflow site number; WQ, water-quality site number.

Statistics: POR, time period used in test; test, regression (Reg), Kendall Theil (KT); log transformed; yes (Y) or no $(\mathrm{N})$; p-value, measure of significance of regressor at 0.01; slope, regression slope; base median, median of first 2 years of record; status median, median of last 3 years of record; magnitude, minimum (min) and maximum (max) percentage change in trend for indicated period of record; tend direction, UP, down (DN), or not significant (NS); relative rank, each individual status yield (pound per acre) compared to all others of the same parameter; shaded areas are significant at 99-percent confidence level; -, not applicable or insufficient data. 
Appendix 1. Trends in streamflow and load data for 9 River Input Monitoring Program sites and 21 Multi-Agency Nontidal Program sites in the Chesapeake Bay Watershed-Continued

\begin{tabular}{|c|c|c|c|c|c|c|c|c|c|c|c|c|}
\hline \multirow{3}{*}{ Parameter } & \multicolumn{2}{|c|}{ Station } & \multicolumn{10}{|c|}{ Statistics } \\
\hline & \multirow{2}{*}{ Flow } & \multirow{2}{*}{$W Q$} & \multirow{2}{*}{ POR } & \multirow{2}{*}{ Test } & \multirow{2}{*}{$\begin{array}{l}\mathrm{Log} \\
\text { transformation }\end{array}$} & \multirow{2}{*}{$p$-value } & \multirow{2}{*}{$\begin{array}{l}\text { Base-median } \\
\text { yields }\end{array}$} & \multirow{2}{*}{$\begin{array}{l}\text { Status-median } \\
\text { yields }\end{array}$} & \multicolumn{2}{|c|}{ Magnitude } & \multirow{2}{*}{$\begin{array}{c}\text { Trend } \\
\text { direction }\end{array}$} & \multirow{2}{*}{$\begin{array}{l}\text { Relative } \\
\text { rank }\end{array}$} \\
\hline & & & & & & & & & Minimum & Maximum & & \\
\hline
\end{tabular}

\section{RIVER INPUT SITES}

01491000 - Choptank River near Greensboro, Md. (map ID site \#9)

\begin{tabular}{|c|c|c|c|c|c|c|c|c|c|c|c|c|}
\hline Q & 01491000 & 01491000 & Jan85-Dec98 & Reg & Y & 0.0004 & 95.8 & - & 40 & 108 & UP & - \\
\hline $\mathrm{TN}$ & 01491000 & 01491000 & Jan85-Dec98 & Reg & $Y$ & .0026 & 2.66 & 6.47 & 25 & 179 & UP & 23 \\
\hline TKN & 01491000 & 01491000 & Jan85-Dec98 & Reg & Y & .3251 & - & - & -23 & 117 & NS & 一 \\
\hline NOx & 01491000 & 01491000 & Jan85-Dec98 & Reg & Y & .0001 & 1.60 & 3.60 & 51 & 201 & UP & 18 \\
\hline TP & 01491000 & 01491000 & Jan85-Dec98 & Reg & $\mathrm{Y}$ & .0375 & .086 & .253 & 4 & 223 & NS & 17 \\
\hline DP & 01491000 & 01491000 & Jan85-Dec98 & Reg & $\mathrm{Y}$ & .0001 & .024 & .124 & 79 & 433 & UP & 22 \\
\hline DIP & 01491000 & 01491000 & Jan85-Dec98 & Reg & Y & .0001 & .020 & .106 & 103 & 479 & UP & 35 \\
\hline SED & 01491000 & 01491000 & Jan85-Dec98 & Reg & $\mathrm{Y}$ & .2553 & 9.87 & 31.8 & -52 & 274 & NS & 0 \\
\hline
\end{tabular}

01578310 - Susquehanna River at Conowingo, Md. (map ID site t8)

\begin{tabular}{|c|c|c|c|c|c|c|c|c|c|c|c|c|}
\hline$Q$ & 01578310 & 01578310 & Jan85-Dec98 & Reg & Y & .5522 & 29,700 & - & -20 & 52 & NS & 一 \\
\hline $\mathrm{TN}$ & 01578310 & 01578310 & Jan85-Dec98 & Reg & $Y$ & .4515 & 6.88 & 6.99 & -37 & 22 & NS & 25 \\
\hline TKN & 01578310 & 01578310 & Jan85-Dec98 & Reg & $Y$ & .0001 & - & - & -31 & -65 & DN & - \\
\hline NOx & 01578310 & 01578310 & Jan85-Dec98 & Reg & $Y$ & .4414 & 4.23 & 5.94 & -18 & 59 & NS & 32 \\
\hline TP & 01578310 & 01578310 & Jan85-Dec98 & Reg & Y & .0058 & .205 & .117 & -17 & -66 & DN & 0 \\
\hline DP & 01578310 & 01578310 & Jan85-Dec98 & Reg & $Y$ & .0005 & .087 & .051 & -29 & -69 & DN & 0 \\
\hline DIP & 01578310 & 01578310 & Jan85-Dec98 & Reg & Y & .6533 & .036 & .050 & -30 & 77 & NS & 10 \\
\hline SED & 01578310 & 01578310 & Jan85-Dec98 & Reg & $Y$ & .2673 & 47.0 & 55.1 & -23 & 157 & NS & 4 \\
\hline
\end{tabular}

01594440 - Patuxent River near Bowie, Md. (map ID site \#11)

\begin{tabular}{|c|c|c|c|c|c|c|c|c|c|c|c|c|}
\hline Q & 01594440 & 01594440 & Jan85-Dec98 & Reg & Y & .0001 & 305 & - & 39 & 136 & UP & - \\
\hline $\mathrm{TN}$ & 01594440 & 01594440 & Jan85-Dec98 & Reg & Y & .0001 & 8.52 & 8.31 & -24 & -49 & DN & 32 \\
\hline TKN & 01594440 & 01594440 & Jan85-Dec98 & Reg & Y & .0001 & - & - & -25 & -57 & DN & - \\
\hline NOx & 01594440 & 01594440 & Jan85-Dec98 & Reg & $Y$ & .0001 & 5.63 & 5.30 & -25 & -46 & DN & 28 \\
\hline TP & 01594440 & 01594440 & Jan85-Dec98 & Reg & $Y$ & .0001 & .564 & .487 & -36 & -66 & DN & 47 \\
\hline DP & 01594440 & 01594440 & Jan85-Dec98 & Reg & $Y$ & .0001 & .247 & .152 & -72 & -78 & DN & 30 \\
\hline DIP & 01594440 & 01594440 & Jan85-Dec98 & Reg & Y & .0097 & .185 & .156 & -7 & -38 & DN & 57 \\
\hline SED & 01594440 & 01594440 & Jan85-Dec98 & Reg & $Y$ & .7021 & 75.2 & 175 & -51 & 61 & NS & 44 \\
\hline
\end{tabular}


Appendix 1. Trends in streamflow and load data for 9 River Input Monitoring Program sites and 21 Multi-Agency Nontidal Program sites in the Chesapeake Bay Watershed-Continued

\begin{tabular}{|c|c|c|c|c|c|c|c|c|c|c|c|c|}
\hline \multirow{3}{*}{ Parameter } & \multicolumn{2}{|c|}{ Station } & \multicolumn{10}{|c|}{ Statistics } \\
\hline & \multirow{2}{*}{ Flow } & \multirow{2}{*}{ WQ } & \multirow{2}{*}{ POR } & \multirow{2}{*}{ Test } & \multirow{2}{*}{$\begin{array}{c}\text { Log } \\
\text { transformation }\end{array}$} & \multirow{2}{*}{$\mathrm{p}$-value } & \multirow{2}{*}{$\begin{array}{l}\text { Base-median } \\
\text { yields }\end{array}$} & \multirow{2}{*}{$\begin{array}{l}\text { Status-median } \\
\text { yields }\end{array}$} & \multicolumn{2}{|c|}{ Magnitude } & \multirow{2}{*}{$\begin{array}{c}\text { Trend } \\
\text { direction }\end{array}$} & \multirow{2}{*}{$\begin{array}{c}\text { Relative } \\
\text { rank }\end{array}$} \\
\hline & & & & & & & & & Minimum & Maximum & & \\
\hline \multicolumn{13}{|c|}{01646580 - Potomac River at Chain Bridge, Md. (map ID site \#28) } \\
\hline Q & 01646580 & PR01 & Jan85-Dec98 & Reg & Y & 0.008 & 8,840 & - & 16 & 154 & UP & - \\
\hline $\mathrm{TN}$ & 01646580 & PR01 & Jan85-Dec98 & Reg & $\mathrm{Y}$ & .0170 & 3.28 & 11.0 & 12 & 197 & NS & 44 \\
\hline TKN & 01646580 & PR01 & Jan85-Dec98 & Reg & $\mathrm{Y}$ & .3638 & - & - & -25 & 123 & NS & - \\
\hline NOx & 01646580 & PR01 & Jan85-Dec98 & Reg & $\mathrm{Y}$ & .0002 & 1.71 & 8.87 & 59 & 158 & UP & 48 \\
\hline TP & 01646580 & PR01 & Jan85-Dec98 & Reg & $\mathrm{Y}$ & .1957 & .155 & .402 & -21 & 213 & NS & 36 \\
\hline DP & 01646580 & PR01 & Jan85-Dec98 & Reg & $\mathrm{Y}$ & .6746 & .090 & .167 & -35 & 96 & NS & 34 \\
\hline DIP & 01646580 & PR01 & Jan85-Dec98 & Reg & Y & .2682 & .047 & .128 & -22 & 143 & NS & 45 \\
\hline SED & 01646580 & PR01 & Jan85-Dec98 & Reg & $\mathrm{Y}$ & .6131 & 49.2 & 125 & -70 & -19 & NS & 28 \\
\hline \multicolumn{13}{|c|}{01668000 - Rappahannock River near Fredericksburg, Va. (map ID site \#24) } \\
\hline Q & 01668000 & 01668000 & Jan88-Dec98 & Reg & Y & .1314 & - & - & -11 & 140 & NS & - \\
\hline $\mathrm{TN}$ & 01668000 & 01668000 & Jan88-Dec98 & Reg & Y & .6653 & 1.98 & 4.53 & -44 & 147 & NS & 14 \\
\hline NOx & 01668000 & 01668000 & Jan88-Dec98 & Reg & $\mathrm{Y}$ & .9210 & 1.04 & 2.50 & -56 & 150 & NS & 29 \\
\hline TP & 01668000 & 01668000 & Jan88-Dec98 & Reg & Y & .7623 & .144 & .383 & -58 & 225 & NS & 12 \\
\hline DIP & 01668000 & 01668000 & Jan88-Dec98 & Reg & $\mathrm{Y}$ & .3115 & .024 & .068 & -29 & 194 & NS & 18 \\
\hline TSS & 01668000 & 01668000 & Jan88-Dec98 & Reg & $\mathrm{Y}$ & .7115 & 60.7 & 187 & -70 & 490 & NS & 100 \\
\hline \multicolumn{13}{|c|}{01673000 - Pamunkey River near Hanover, Va. (map ID site \#25) } \\
\hline Q & 01673000 & 01673000 & Jan89-Dec98 & Reg & Y & .6040 & - & - & -31 & 190 & NS & - \\
\hline $\mathrm{TN}$ & 01673000 & 01673000 & Jan89-Dec98 & Reg & $\mathrm{Y}$ & .6918 & 2.14 & 2.23 & -36 & 96 & NS & 4 \\
\hline NOx & 01673000 & 01673000 & Jan89-Dec98 & Reg & Y & .0877 & .647 & 1.02 & -5 & 49 & NS & 9 \\
\hline TP & 01673000 & 01673000 & Jan89-Dec98 & Reg & Y & .7414 & .206 & .214 & -40 & 103 & NS & 3 \\
\hline DIP & 01673000 & 01673000 & Jan89-Dec98 & Reg & Y & .0001 & .044 & .070 & 54 & 233 & UP & 19 \\
\hline TSS & 01673000 & 01673000 & Jan89-Dec98 & Reg & $\mathrm{Y}$ & .6871 & 81.9 & 78.3 & -72 & 132 & NS & 35 \\
\hline
\end{tabular}

01674500 - Mattaponi River near Beulahville, Va. (map ID site \#27)

\begin{tabular}{|c|c|c|c|c|c|c|c|c|c|c|c|c|}
\hline$Q$ & 01674500 & 01674500 & Jan89-Dec98 & Reg & $Y$ & .1075 & - & - & -9 & 60 & NS & - \\
\hline $\mathrm{TN}$ & 01674500 & 01674500 & Jan89-Dec98 & Reg & $Y$ & .5434 & 2.24 & 1.70 & -56 & 55 & NS & 1 \\
\hline NOx & 01674500 & 01674500 & Jan89-Dec98 & Reg & $Y$ & .3916 & .383 & .376 & -53 & 34 & NS & 0 \\
\hline TP & 01674500 & 01674500 & Jan89-Dec98 & Reg & $Y$ & .3736 & .113 & .161 & -61 & 42 & NS & 0 \\
\hline DIP & 01674500 & 01674500 & Jan89-Dec98 & Reg & $Y$ & .0907 & .029 & .056 & -7 & 171 & NS & 12 \\
\hline TSS & 01674500 & 01674500 & Jan89-Dec98 & Reg & $Y$ & .9901 & 11.6 & 33.2 & -59 & 140 & NS & 6 \\
\hline
\end{tabular}


Appendix 1. Trends in streamflow and load data for 9 River Input Monitoring Program sites and 21 Multi-Agency Nontidal Program sites in the Chesapeake Bay Watershed-Continued

\begin{tabular}{|c|c|c|c|c|c|c|c|c|c|c|c|c|}
\hline \multirow{3}{*}{ Parameter } & \multicolumn{2}{|c|}{ Station } & \multicolumn{10}{|c|}{ Statistics } \\
\hline & \multirow{2}{*}{ Flow } & \multirow{2}{*}{ WQ } & \multirow{2}{*}{ POR } & \multirow{2}{*}{ Test } & \multirow{2}{*}{$\begin{array}{c}\log \\
\text { transformation }\end{array}$} & \multirow{2}{*}{ p-value } & \multirow{2}{*}{$\begin{array}{l}\text { Base-median } \\
\text { yields }\end{array}$} & \multirow{2}{*}{$\begin{array}{l}\text { Status-median } \\
\text { yields }\end{array}$} & \multicolumn{2}{|c|}{ Magnitude } & \multirow{2}{*}{$\begin{array}{l}\text { Trend } \\
\text { direction }\end{array}$} & \multirow{2}{*}{$\begin{array}{c}\text { Relative } \\
\text { rank }\end{array}$} \\
\hline & & & & & & & & & Minimum & Maximum & & \\
\hline \multicolumn{13}{|c|}{02035000 - James River at Cartersville, Va. (map ID site \#29) } \\
\hline Q & 02035000 & 02035000 & Jan88-Dec98 & Reg & Y & 0.3386 & - & - & -17 & 72 & NS & - \\
\hline TN & 02035000 & 02035000 & Jan88-Dec98 & Reg & Y & .8483 & 1.66 & 1.93 & -45 & 64 & NS & 2 \\
\hline NOx & 02035000 & 02035000 & Jan88-Dec98 & Reg & Y & .5389 & .630 & .758 & -53 & 49 & NS & 5 \\
\hline TP & 02035000 & 02035000 & Jan88-Dec98 & Reg & $Y$ & .0611 & .358 & .291 & -65 & 2 & NS & 2 \\
\hline DIP & 02035000 & 02035000 & Jan88-Dec98 & Reg & $\mathrm{Y}$ & .0001 & .258 & .118 & -50 & -68 & DN & 40 \\
\hline TSS & 02035000 & 02035000 & Jan88-Dec98 & Reg & $Y$ & .9823 & 41.6 & 122 & -67 & 193 & NS & 64 \\
\hline \multicolumn{13}{|c|}{02041650 - Appomattox River at Matoaca, Va. (map ID site \#30) } \\
\hline Q & 02041650 & 02041650 & Jan89-Dec98 & Reg & Y & .6742 & - & - & -42 & 43 & NS & - \\
\hline $\mathrm{TN}$ & 02041650 & 02041650 & Jan89-Dec98 & Reg & $\mathrm{Y}$ & .2361 & 1.50 & 1.49 & -55 & 21 & NS & 0 \\
\hline NOx & 02041650 & 02041650 & Jan89-Dec98 & Reg & $\mathrm{Y}$ & .3779 & .376 & .401 & -44 & 24 & NS & 0 \\
\hline TP & 02041650 & 02041650 & Jan89-Dec98 & Reg & Y & .6605 & .106 & .138 & -52 & 58 & NS & 0 \\
\hline DIP & 02041650 & 02041650 & Jan89-Dec98 & Reg & $Y$ & .5865 & .029 & .035 & -28 & 79 & NS & 3 \\
\hline TSS & 02041650 & 02041650 & Jan89-Dec98 & Reg & $Y$ & .6403 & 22.8 & 27.3 & -64 & 86 & NS & 2 \\
\hline
\end{tabular}

MULTI-AGENCY SITES

01531500 - Susquehanna River at Towanda, Pa. (map ID site \#1)

\begin{tabular}{|c|c|c|c|c|c|c|c|c|c|c|c|c|}
\hline Q & 01531500 & TOW & Jan89-Dec98 & Reg & $\mathrm{N}$ & .9172 & 6,520 & 9,860 & -35 & 62 & NS & - \\
\hline TN & 01531500 & TOW & Jan89-Dec98 & Reg & $\mathrm{Y}$ & .0626 & 7.29 & 4.65 & -61 & 2 & NS & 15 \\
\hline NOx & 01531500 & TOW & Jan89-Dec98 & Reg & $\mathrm{Y}$ & .0303 & 4.41 & 2.61 & -64 & -6 & NS & 13 \\
\hline TP & 01531500 & TOW & Jan89-Dec98 & Reg & $\mathrm{Y}$ & .0238 & .357 & .230 & -72 & -9 & NS & 14 \\
\hline DP & 01531500 & TOW & Jan89-Dec98 & Reg & $\mathrm{Y}$ & .0001 & .161 & .082 & -39 & -76 & DN & 9 \\
\hline DIP & 01531500 & TOW & Jan89-Dec98 & Reg & $\mathrm{Y}$ & .0300 & .055 & .029 & -61 & -5 & NS & 0 \\
\hline SED & 01531500 & TOW & Jan89-Dec98 & Reg & $Y$ & .2346 & 349 & 205 & -77 & 43 & NS & 54 \\
\hline \multicolumn{13}{|c|}{01540500 - Susquehanna River at Danville, Pa. (map ID site \#2) } \\
\hline Q & 01540500 & DAN & Jan85-Dec98 & Reg & $\mathrm{N}$ & .1750 & 11,000 & 14,600 & -10 & 79 & NS & - \\
\hline TN & 01540500 & DAN & Jan85-Dec98 & Reg & $\mathrm{Y}$ & .3286 & 5.70 & 4.77 & -43 & 20 & NS & 15 \\
\hline NOx & 01540500 & DAN & Jan85-Dec98 & Reg & $\mathrm{Y}$ & 6540 & 2.79 & 2.99 & -24 & 56 & NS & 15 \\
\hline $\mathrm{TP}$ & 01540500 & DAN & Jan85-Dec98 & Reg & $\mathrm{Y}$ & .0309 & .338 & .197 & -63 & -5 & NS & 10 \\
\hline DP & 01540500 & DAN & Jan85-Dec98 & Reg & $\mathrm{Y}$ & .0001 & .102 & .055 & -46 & -80 & DN & 1 \\
\hline DIP & 01540500 & DAN & Jan85-Dec98 & Reg & $\mathrm{Y}$ & .0870 & .048 & .031 & -55 & 5 & NS & 1 \\
\hline SED & 01540500 & DAN & Jan85-Dec98 & Reg & $\mathrm{Y}$ & .4657 & 193 & 119 & -122 & 228 & NS & 26 \\
\hline
\end{tabular}


Appendix 1. Trends in streamflow and load data for 9 River Input Monitoring Program sites and 21 Multi-Agency Nontidal Program sites in the Chesapeake Bay Watershed-Continued

\begin{tabular}{|c|c|c|c|c|c|c|c|c|c|c|c|c|}
\hline \multirow{3}{*}{ Parameter } & \multicolumn{2}{|c|}{ Station } & \multicolumn{10}{|c|}{ Statistics } \\
\hline & \multirow{2}{*}{ Flow } & \multirow{2}{*}{ WQ } & \multirow{2}{*}{ POR } & \multirow{2}{*}{ Test } & \multirow{2}{*}{$\begin{array}{l}\log \\
\text { transformation }\end{array}$} & \multirow{2}{*}{$p$-value } & \multirow{2}{*}{$\begin{array}{l}\text { Base-median } \\
\text { yields }\end{array}$} & \multirow{2}{*}{$\begin{array}{c}\text { Status-median } \\
\text { yields }\end{array}$} & \multicolumn{2}{|c|}{ Magnitude } & \multirow{2}{*}{$\begin{array}{c}\text { Trend } \\
\text { direction }\end{array}$} & \multirow{2}{*}{$\begin{array}{l}\text { Relative } \\
\text { rank }\end{array}$} \\
\hline & & & & & & & & & Minimum & Maximum & & \\
\hline \multicolumn{13}{|c|}{01553500 - West Branch Susquehanna River at Lewisburg, Pa. (map ID site \#3) } \\
\hline Q & 01553500 & LEW & Jan85-Dec98 & Reg & Y & 0.5050 & 8,160 & 10,500 & -20 & 59 & NS & - \\
\hline $\mathrm{TN}$ & 01553500 & LEW & Jan85-Dec98 & Reg & $\mathrm{Y}$ & .0875 & 5.85 & 4.13 & -49 & 5 & NS & 12 \\
\hline NOx & 01553500 & LEW & Jan85-Dec98 & Reg & $Y$ & .5225 & 2.98 & 2.86 & -35 & 25 & NS & 14 \\
\hline TP & 01553500 & LEW & Jan85-Dec98 & Reg & Y & .0008 & .204 & .094 & -30 & -73 & DN & 0 \\
\hline DP & 01553500 & LEW & Jan85-Dec98 & Reg & Y & .0001 & .129 & .051 & -52 & -77 & DN & 0 \\
\hline DIP & 01553500 & LEW & Jan85-Dec98 & Reg & $\mathrm{Y}$ & .0693 & .049 & .027 & -47 & 2 & NS & 0 \\
\hline SED & 01553500 & LEW & Jan85-Dec98 & Reg & Y & .7331 & 123 & 56.8 & -66 & 359 & NS & 5 \\
\hline \multicolumn{13}{|c|}{01567000 - Juniata River at Newport, Pa. (map ID site \#4) } \\
\hline Q & 01567000 & JUN & Jan85-Dec98 & Reg & Y & .0033 & 2,420 & 5,070 & 19 & 131 & UP & - \\
\hline $\mathrm{TN}$ & 01567000 & JUN & Jan85-Dec98 & Reg & Y & .4520 & 4.29 & 7.56 & -22 & 74 & NS & 28 \\
\hline NOx & 01567000 & JUN & Jan85-Dec98 & Reg & Y & .1696 & 2.85 & 5.54 & -11 & 93 & NS & 29 \\
\hline TP & 01567000 & JUN & Jan85-Dec98 & Reg & Y & .0486 & .196 & .284 & -59 & -1 & NS & 21 \\
\hline $\mathrm{DP}$ & 01567000 & JUN & Jan85-Dec98 & Reg & $Y$ & .0015 & .105 & .115 & -60 & -20 & DN & 19 \\
\hline DIP & 01567000 & JUN & Jan85-Dec98 & Reg & Y & .0246 & .118 & .061 & -64 & -7 & NS & 15 \\
\hline SED & 01567000 & JUN & Jan85-Dec98 & Reg & $Y$ & .4987 & 80.1 & 208 & -62 & 210 & NS & 55 \\
\hline \multicolumn{13}{|c|}{01576000 - Susquehanna River at Marietta, Pa. (map ID site \#6) } \\
\hline Q & 01576000 & MAR & Jan85-Dec98 & Reg & Y & .1388 & 25,500 & 40,000 & -8 & 88 & NS & - \\
\hline TN & 01576000 & MAR & Jan85-Dec98 & Reg & Y & .4052 & 4.96 & 6.27 & -45 & 27 & NS & 22 \\
\hline NOx & 01576000 & MAR & Jan85-Dec98 & Reg & Y & .9718 & 3.25 & 4.81 & -34 & 49 & NS & 25 \\
\hline TP & 01576000 & MAR & Jan85-Dec98 & Reg & Y & .1047 & .196 & .200 & -73 & -12 & NS & 10 \\
\hline DP & 01576000 & MAR & Jan85-Dec98 & Reg & Y & .0008 & .095 & .080 & -26 & -66 & DN & 9 \\
\hline DIP & 01576000 & MAR & Jan85-Dec98 & Reg & $\mathrm{Y}$ & .0121 & .021 & .039 & 15 & 187 & NS & 5 \\
\hline SED & 01576000 & MAR & Jan85-Dec98 & Reg & Y & .6001 & 84.0 & 117 & -93 & 168 & NS & 25 \\
\hline
\end{tabular}


Appendix 1. Trends in streamflow and load data for 9 River Input Monitoring Program sites and 21 Multi-Agency Nontidal Program sites in the Chesapeake Bay Watershed-Continued

\begin{tabular}{|c|c|c|c|c|c|c|c|c|c|c|c|c|}
\hline \multirow{3}{*}{ Parameter } & \multicolumn{2}{|c|}{ Station } & \multicolumn{10}{|c|}{ Statistics } \\
\hline & \multirow{2}{*}{ Flow } & \multirow{2}{*}{ WQ } & \multirow{2}{*}{ POR } & \multirow{2}{*}{ Test } & \multirow{2}{*}{$\begin{array}{l}\log \\
\text { transformation }\end{array}$} & \multirow{2}{*}{$p$-value } & \multirow{2}{*}{$\begin{array}{c}\text { Base-median } \\
\text { yields }\end{array}$} & \multirow{2}{*}{$\begin{array}{l}\text { Status-median } \\
\text { yields }\end{array}$} & \multicolumn{2}{|c|}{ Magnitude } & \multirow{2}{*}{$\begin{array}{c}\text { Trend } \\
\text { direction }\end{array}$} & \multirow{2}{*}{$\begin{array}{l}\text { Relative } \\
\text { rank }\end{array}$} \\
\hline & & & & & & & & & Minimum & Maximum & & \\
\hline \multicolumn{13}{|c|}{01576754 - Conestoga River at Conestoga, Pa. (map ID site \#7) } \\
\hline Q & 01576754 & CON & Jan85-Dec98 & Reg & Y & 0.0529 & 451 & 747 & 0 & 69 & NS & - \\
\hline $\mathrm{TN}$ & 01576754 & CON & Jan85-Dec98 & Reg & $\mathrm{Y}$ & .5246 & 26.7 & 37.5 & -16 & 40 & NS & 100 \\
\hline NOx & 01576754 & CON & Jan85-Dec98 & Reg & Y & .2683 & 19.7 & 30.5 & -10 & 44 & NS & 100 \\
\hline TP & 01576754 & $\mathrm{CON}$ & Jan85-Dec98 & SK & $\mathrm{N}$ & .2305 & 1.67 & 1.45 & -61 & -7 & NS & 100 \\
\hline DP & 01576754 & CON & Jan85-Dec98 & Reg & Y & .0001 & .955 & .608 & -40 & -69 & DN & 100 \\
\hline DIP & 01576754 & CON & Jan85-Dec98 & Reg & Y & .0001 & .905 & .536 & -39 & -69 & DN & 100 \\
\hline SED & 01576754 & CON & Jan85-Dec98 & Reg & $\mathrm{Y}$ & .5241 & 337 & 452 & -138 & 57 & NS & 100 \\
\hline \multicolumn{13}{|c|}{01570000 - Conodoguinet Creek near Hogestown, Pa. (map ID site \#5) } \\
\hline Q & 01570000 & WQN0213 & Jan85-Dec98 & Reg & Y & .0001 & - & - & 59 & 207 & UP & - \\
\hline $\mathrm{TN}$ & 01570000 & WQN0213 & Jan85-Dec98 & Reg & Y & .0001 & 7.44 & 20.1 & 84 & 239 & UP & 85 \\
\hline NOx & 01570000 & WQN0213 & Jan85-Dec98 & - & - & - & - & - & - & - & - & - \\
\hline $\mathrm{TP}$ & 01570000 & WQN0213 & Jan85-Dec98 & Reg & $\mathrm{Y}$ & .4076 & .047 & .251 & -70 & 63 & NS & 17 \\
\hline DP & 01570000 & WQN0213 & Jan85-Dec98 & Reg & Y & .0015 & .034 & .088 & -72 & -93 & DN & 11 \\
\hline DIP & 01570000 & WQN0213 & Jan85-Dec98 & Reg & Y & .0001 & .224 & .066 & -60 & -90 & DN & 17 \\
\hline TSS & 01570000 & WQN0213 & Jan85-Dec98 & 一 & - & - & - & - & 一 & 一 & - & - \\
\hline \multicolumn{13}{|c|}{01586000 - North Branch Patapsco River at Cedarhurst, Md. (map ID site \#12) } \\
\hline Q & 01586000 & NPA0165 & Jan85-Dec98 & Reg & Y & .0001 & - & - & 30 & 115 & UP & - \\
\hline $\mathrm{TN}$ & 01586000 & NPA0165 & Jan85-Dec98 & Reg & Y & .0001 & 8.69 & 22.5 & 75 & 175 & UP & 96 \\
\hline TKN & 01586000 & NPA0165 & Jan85-Dec98 & Reg & Y & .6894 & - & - & -45 & 48 & NS & - \\
\hline $\mathrm{NOx}$ & 01586000 & NPA0165 & Jan85-Dec98 & Reg & Y & .0001 & 7.24 & 16.5 & 60 & 144 & UP & 92 \\
\hline TP & 01586000 & NPA0165 & Jan85-Dec98 & Reg & $\mathrm{Y}$ & .7424 & .120 & .236 & -55 & 141 & NS & 15 \\
\hline DP & 01586000 & NPA0165 & Jan85-Dec98 & - & - & - & - & - & - & - & - & - \\
\hline DIP & 01586000 & NPA0165 & Jan85-Dec98 & - & - & - & - & - & - & - & - & - \\
\hline TSS & 01586000 & NPA0165 & Jan85-Dec98 & Reg & $\mathrm{Y}$ & .0672 & 17.6 & 72.7 & -7 & 824 & NS & 32 \\
\hline
\end{tabular}


Appendix 1. Trends in streamflow and load data for 9 River Input Monitoring Program sites and 21 Multi-Agency Nontidal Program sites in the Chesapeake Bay Watershed-Continued

\begin{tabular}{|c|c|c|c|c|c|c|c|c|c|c|c|c|}
\hline \multirow{3}{*}{ Parameter } & \multicolumn{2}{|c|}{ Station } & \multicolumn{10}{|c|}{ Statistics } \\
\hline & \multirow{2}{*}{ Flow } & \multirow{2}{*}{ WQ } & \multirow{2}{*}{ POR } & \multirow{2}{*}{ Test } & \multirow{2}{*}{$\begin{array}{l}\log \\
\text { transformation }\end{array}$} & \multirow{2}{*}{$p$-value } & \multirow{2}{*}{$\begin{array}{l}\text { Base-median } \\
\text { yields }\end{array}$} & \multirow{2}{*}{$\begin{array}{l}\text { Status-median } \\
\text { yields }\end{array}$} & \multicolumn{2}{|c|}{ Magnitude } & \multirow{2}{*}{$\begin{array}{l}\text { Trend } \\
\text { direction }\end{array}$} & \multirow{2}{*}{$\begin{array}{l}\text { Relative } \\
\text { rank }\end{array}$} \\
\hline & & & & & & & & & Minimum & Maximum & & \\
\hline \multicolumn{13}{|c|}{01592500 - Patuxent River near Laurel, Md. (map ID site \#10) } \\
\hline Q & 01592500 & РXT0809 & Jan85-Dec98 & Reg & Y & 0.0039 & - & - & 26 & 222 & UP & - \\
\hline $\mathrm{TN}$ & 01592500 & PXT0809 & Jan85-Dec98 & Reg & Y & .0006 & 0.622 & 6.68 & 49 & 306 & UP & 24 \\
\hline TKN & 01592500 & РХT0809 & Jan85-Dec98 & Reg & $\mathrm{Y}$ & .0018 & - & - & 35 & 225 & UP & - \\
\hline NOx & 01592500 & РХT0809 & Jan85-Dec98 & Reg & $\mathrm{Y}$ & .0008 & .352 & 4.02 & 46 & 303 & UP & 21 \\
\hline TP & 01592500 & РХT0809 & Jan85-Dec98 & Reg & Y & .0079 & .023 & .122 & -6 & -7 & UP & 0 \\
\hline DP & 01592500 & РХT0809 & Jan85-Dec98 & - & - & - & - & - & - & - & - & - \\
\hline DIP & 01592500 & РХT0809 & Jan85-Dec98 & - & - & - & - & - & - & - & - & - \\
\hline TSS & 01592500 & РХT0809 & Jan85-Dec98 & Reg & Y & .0001 & 3.27 & 32.1 & 139 & 516 & UP & 5 \\
\hline \multicolumn{13}{|c|}{01599000 - Georges Creek near Franklin, Md. (map ID site \#13) } \\
\hline$Q$ & 01599000 & GEO0009 & Jan85-Dec98 & Reg & $\mathrm{Y}$ & .1633 & - & - & -11 & 104 & NS & - \\
\hline $\mathrm{TN}$ & 01599000 & GEO0009 & Jan85-Dec98 & Reg & $\mathrm{Y}$ & .6263 & 3.65 & 5.08 & -40 & 35 & NS & 17 \\
\hline TKN & 01599000 & GEO0009 & Jan85-Dec98 & Reg & $\mathrm{Y}$ & .2113 & - & - & -52 & 18 & NS & - \\
\hline NOx & 01599000 & GEO0009 & Jan85-Dec98 & - & - & - & - & - & - & - & - & - \\
\hline TP & 01599000 & GEO0009 & Jan85-Dec98 & Reg & $\mathrm{Y}$ & .1684 & .178 & .214 & -48 & 12 & NS & 12 \\
\hline DP & 01599000 & GEO0009 & Jan85-Dec98 & - & - & - & - & - & - & - & - & - \\
\hline DIP & 01599000 & GEO0009 & Jan85-Dec98 & - & - & - & - & - & - & - & - & - \\
\hline TSS & 01599000 & GEO0009 & Jan85-Dec98 & Reg & $\mathrm{Y}$ & .0491 & 45.9 & 165 & 1 & 226 & NS & 92 \\
\hline \multicolumn{13}{|c|}{01601500 - Wills Creek near Cumberland, Md. (map ID site \#14) } \\
\hline$Q$ & 01601500 & WIL0013 & Jan85-Dec98 & Reg & $Y$ & .0178 & - & - & -17 & 98 & NS & - \\
\hline $\mathrm{TN}$ & 01601500 & WIL0013 & Jan85-Dec98 & Reg & Y & .4155 & 3.84 & 5.37 & -57 & 42 & NS & 18 \\
\hline DNH & 01601500 & WIL0013 & Jan85-Dec98 & Reg & $\mathrm{Y}$ & .0105 & - & - & 19 & 242 & NS & - \\
\hline TKN & 01601500 & WIL0013 & Jan85-Dec98 & Reg & $\mathrm{Y}$ & .1659 & - & - & -60 & 17 & NS & - \\
\hline NOx & 01601500 & WIL0013 & Jan85-Dec98 & - & - & - & - & - & - & - & - & - \\
\hline TP & 01601500 & WIL0013 & Jan85-Dec98 & Reg & $\mathrm{Y}$ & .2805 & .077 & .195 & -14 & 47 & NS & 10 \\
\hline DP & 01601500 & WIL0013 & Jan85-Dec98 & - & - & - & - & - & - & - & - & - \\
\hline DIP & 01601500 & WIL0013 & Jan85-Dec98 & - & - & - & - & - & - & - & - & - \\
\hline TSS & 01601500 & WIL0013 & Jan85-Dec98 & Reg & $\mathrm{Y}$ & 2999 & 31.4 & 76.3 & -32 & 55 & NS & 34 \\
\hline
\end{tabular}


Appendix 1. Trends in streamflow and load data for 9 River Input Monitoring Program sites and 21 Multi-Agency Nontidal Program sites in the Chesapeake Bay Watershed-Continued

\begin{tabular}{|c|c|c|c|c|c|c|c|c|c|c|c|c|}
\hline \multirow{3}{*}{ Parameter } & \multicolumn{2}{|c|}{ Station } & \multicolumn{10}{|c|}{ Statistics } \\
\hline & \multirow{2}{*}{ Flow } & \multirow{2}{*}{ WQ } & \multirow{2}{*}{ POR } & \multirow{2}{*}{ Test } & \multirow{2}{*}{$\begin{array}{l}\log \\
\text { transformation }\end{array}$} & \multirow{2}{*}{$p$-value } & \multirow{2}{*}{$\begin{array}{l}\text { Base-median } \\
\text { yields }\end{array}$} & \multirow{2}{*}{$\begin{array}{c}\text { Status-median } \\
\text { yields }\end{array}$} & \multicolumn{2}{|c|}{ Magnitude } & \multirow{2}{*}{$\begin{array}{c}\text { Trend } \\
\text { direction }\end{array}$} & \multirow{2}{*}{$\begin{array}{l}\text { Relative } \\
\text { rank }\end{array}$} \\
\hline & & & & & & & & & Minimum & Maximum & & \\
\hline \multicolumn{13}{|c|}{01610000 - Potomac River at Paw Paw, W. Va. (map ID site \#15) } \\
\hline Q & 01610000 & РОТ2766 & Jan85-Dec98 & Reg & Y & 0.2156 & - & - & -12 & 80 & NS & - \\
\hline $\mathrm{TN}$ & 01610000 & РОT2766 & Jan85-Dec98 & Reg & $\mathrm{Y}$ & .6821 & 2.89 & 4.14 & -28 & 65 & NS & 12 \\
\hline DNH & 01610000 & РОТ2766 & Jan85-Dec98 & Reg & Y & .001 & - & - & -17 & -51 & DN & - \\
\hline TKN & 01610000 & РОТ2766 & Jan85-Dec98 & Reg & $\mathrm{Y}$ & .3641 & - & - & -49 & 28 & NS & - \\
\hline NOx & 01610000 & РОТ2766 & Jan85-Dec98 & - & - & - & - & - & - & - & - & - \\
\hline TP & 01610000 & РОТ2766 & Jan85-Dec98 & Reg & $\mathrm{Y}$ & .4333 & .145 & .169 & -56 & 42 & NS & 6 \\
\hline $\mathrm{DP}$ & 01610000 & РОТ2766 & Jan85-Dec98 & - & - & - & - & - & - & - & - & - \\
\hline DIP & 01610000 & РОТ2766 & Jan85-Dec98 & - & - & - & - & - & - & - & - & - \\
\hline TSS & 01610000 & РОТ2766 & Jan85-Dec98 & Reg & $\mathrm{Y}$ & .7989 & 30.2 & 82.3 & -52 & 162 & NS & 38 \\
\hline \multicolumn{13}{|c|}{01613000 - Potomac River at Hancock, Md. (map ID site \#16) } \\
\hline Q & 01613000 & РОT2386 & Jan85-Dec98 & Reg & Y & .1999 & - & - & -12 & 81 & NS & - \\
\hline $\mathrm{TN}$ & 01613000 & РОT2386 & Jan85-Dec98 & Reg & $\mathrm{Y}$ & .3762 & 3.11 & 4.04 & -46 & 26 & NS & 12 \\
\hline $\mathrm{TNH}$ & 01613000 & РОТ2386 & Jan85-Dec98 & Reg & $\mathrm{Y}$ & .8974 & - & - & -42 & 61 & NS & - \\
\hline TKN & 01613000 & РОТ2386 & Jan85-Dec98 & Reg & Y & .0262 & - & - & -59 & -6 & NS & - \\
\hline NOx & 01613000 & РОТ2386 & Jan85-Dec98 & Reg & $\mathrm{Y}$ & .487 & 1.68 & 2.38 & -49 & 37 & NS & 11 \\
\hline TP & 01613000 & РОТ2386 & Jan85-Dec98 & Reg & Y & .2826 & .133 & .188 & -57 & 28 & NS & 9 \\
\hline $\mathrm{DP}$ & 01613000 & РОТ2386 & Jan85-Dec98 & - & - & - & - & - & - & - & - & - \\
\hline DIP & 01613000 & РОТ2386 & Jan85-Dec98 & - & - & - & - & - & - & - & - & - \\
\hline TSS & 01613000 & РОТ2386 & Jan85-Dec98 & Reg & $\mathrm{Y}$ & .1449 & 27.4 & 94.9 & -21 & 416 & NS & 46 \\
\hline \multicolumn{13}{|c|}{01614500 - Conococheague Creek at Fairview, Md. (map ID site \#17) } \\
\hline Q & 01614500 & CON0180 & Jan85-Dec98 & Reg & Y & .0001 & - & - & 44 & 194 & UP & - \\
\hline TN & 01614500 & CON0180 & Jan85-Dec98 & Reg & Y & .0021 & 8.64 & 24.1 & 22 & 141 & UP & 100 \\
\hline DNH & 01614500 & CON0180 & Jan85-Dec98 & Reg & $\mathrm{Y}$ & .8734 & - & - & -37 & 72 & NS & - \\
\hline TKN & 01614500 & CON0180 & Jan85-Dec98 & Reg & $\mathrm{Y}$ & .5315 & - & - & -26 & 79 & NS & - \\
\hline NOx & 01614500 & CON0180 & Jan85-Dec98 & Reg & $\mathrm{Y}$ & .0052 & 7.43 & 19.2 & 16 & 125 & UP & 100 \\
\hline TP & 01614500 & CON0180 & Jan85-Dec98 & Reg & Y & .8049 & .332 & .524 & -26 & 49 & - & 51 \\
\hline DP & 01614500 & CON0180 & Jan85-Dec98 & - & - & - & - & - & - & - & - & - \\
\hline DIP & 01614500 & CON0180 & Jan85-Dec98 & - & - & - & - & - & - & - & - & - \\
\hline TSS & 01614500 & CON0180 & Jan85-Dec98 & Reg & Y & .0064 & 17.0 & 175 & 42 & 695 & UP & 99 \\
\hline
\end{tabular}


Appendix 1. Trends in streamflow and load data for 9 River Input Monitoring Program sites and 21 Multi-Agency Nontidal Program sites in the Chesapeake Bay Watershed-Continued

\begin{tabular}{|c|c|c|c|c|c|c|c|c|c|c|c|c|}
\hline \multirow{3}{*}{ Parameter } & \multicolumn{2}{|c|}{ Station } & \multicolumn{10}{|c|}{ Statistics } \\
\hline & \multirow{2}{*}{ Flow } & \multirow{2}{*}{ WQ } & \multirow{2}{*}{ POR } & \multirow{2}{*}{ Test } & \multirow{2}{*}{$\begin{array}{l}\log \\
\text { transformation }\end{array}$} & \multirow{2}{*}{$p$-value } & \multirow{2}{*}{$\begin{array}{l}\text { Base-median } \\
\text { yields }\end{array}$} & \multirow{2}{*}{$\begin{array}{l}\text { Status-median } \\
\text { yields }\end{array}$} & \multicolumn{2}{|c|}{ Magnitude } & \multirow{2}{*}{$\begin{array}{c}\text { Trend } \\
\text { direction }\end{array}$} & \multirow{2}{*}{$\begin{array}{c}\text { Relative } \\
\text { rank }\end{array}$} \\
\hline & & & & & & & & & Minimum & Maximum & & \\
\hline \multicolumn{13}{|c|}{01638500 - Potomac River at Point of Rocks, Md. (map ID site \#19) } \\
\hline Q & 01638500 & POT1595 & Jan85-Dec98 & Reg & Y & 0.0073 & - & - & 14 & 128 & UP & - \\
\hline TN & 01638500 & POT1595 & Jan85-Dec98 & Reg & $\mathrm{Y}$ & .0893 & 4.38 & 8.60 & -4 & 93 & NS & 33 \\
\hline DNH & 01638500 & POT1595 & Jan85-Dec98 & Reg & Y & .7494 & - & - & -46 & 57 & NS & - \\
\hline TKN & 01638500 & POT1595 & Jan85-Dec98 & Reg & $\mathrm{Y}$ & .9512 & - & - & -35 & 57 & NS & - \\
\hline NOx & 01638500 & POT1595 & Jan85-Dec98 & Reg & $\mathrm{Y}$ & .0666 & 2.72 & 5.89 & -2 & 99 & NS & 31 \\
\hline TP & 01638500 & POT1595 & Jan85-Dec98 & Reg & $\mathrm{Y}$ & .8323 & .165 & .293 & -40 & 87 & NS & 22 \\
\hline $\mathrm{DP}$ & 01638500 & POT1595 & Jan85-Dec98 & - & - & - & - & - & - & - & - & - \\
\hline DIP & 01638500 & POT1595 & Jan85-Dec98 & - & - & - & - & - & - & - & - & - \\
\hline TSS & 01638500 & POT1595 & Jan85-Dec98 & Reg & $\mathrm{Y}$ & .0616 & 27.0 & 117 & -4 & 485 & NS & 61 \\
\hline \multicolumn{13}{|c|}{01643000 - Monocacy River at Reels Mill Road, Md. (map ID site \#18) } \\
\hline Q & 01643000 & MON0528 & Jan85-Dec98 & Reg & Y & .0121 & - & - & 12 & 142 & NS & - \\
\hline TN & 01643000 & MON0528 & Jan85-Dec98 & Reg & Y & .5954 & 5.45 & 11.0 & -5 & 291 & NS & 44 \\
\hline DNH & 01643000 & MON0528 & Jan85-Dec98 & Reg & $\mathrm{Y}$ & .5601 & - & - & -41 & 166 & NS & - \\
\hline TKN & 01643000 & MON0528 & Jan85-Dec98 & Reg & $\mathrm{Y}$ & .5604 & - & - & -47 & 41 & NS & - \\
\hline NOx & 01643000 & MON0528 & Jan85-Dec98 & Reg & $\mathrm{Y}$ & .0265 & 2.53 & 3.68 & -75 & -9 & NS & 19 \\
\hline TP & 01643000 & MON0528 & Jan85-Dec98 & Reg & Y & .6093 & .285 & .524 & -49 & 48 & NS & 51 \\
\hline $\mathrm{DP}$ & 01643000 & MON0528 & Jan85-Dec98 & - & - & - & - & - & - & - & - & - \\
\hline DIP & 01643000 & MON0528 & Jan85-Dec98 & - & - & - & - & - & - & - & - & - \\
\hline TSS & 01643000 & MON0528 & Jan85-Dec98 & Reg & $\mathrm{Y}$ & .0728 & 18.9 & 82.7 & -5 & 291 & NS & 38 \\
\hline \multicolumn{13}{|c|}{01631000 - S. Fork Shenandoah River near Front Royal, Va. (map ID site \#20) } \\
\hline Q & 01631000 & 1BSSF003.56 & Jan85-Dec98 & Reg & Y & .0006 & - & - & 32 & 163 & UP & - \\
\hline $\mathrm{TN}$ & 01631000 & 1BSSF003.56 & Jan85-Dec98 & Reg & Y & .9501 & 2.21 & 4.41 & -41 & 64 & NS & 14 \\
\hline $\mathrm{TNH}$ & 01631000 & 1BSSF003.56 & Jan85-Dec98 & Reg & $\mathrm{Y}$ & .3919 & - & - & -57 & 40 & NS & - \\
\hline TKN & 01631000 & 1BSSF003.56 & Jan85-Dec98 & Reg & $\mathrm{Y}$ & .0169 & - & - & -70 & -12 & NS & - \\
\hline NOx & 01631000 & 1BSSF003.56 & Jan85-Dec98 & Reg & Y & .002 & 1.48 & 4.92 & 31 & 220 & UP & 26 \\
\hline TP & 01631000 & 1BSSF003.56 & Jan85-Dec98 & Reg & $\mathrm{Y}$ & .3178 & .361 & .599 & -19 & 92 & NS & 61 \\
\hline $\mathrm{DP}$ & 01631000 & 1BSSF003.56 & Jan85-Dec98 & - & - & - & - & - & - & - & - & - \\
\hline DIP & 01631000 & 1BSSF003.56 & Jan85-Dec98 & - & - & - & - & - & - & - & - & - \\
\hline TSS & 01631000 & 1BSSF003.56 & Jan85-Dec98 & - & - & - & - & - & - & - & - & - \\
\hline
\end{tabular}


Appendix 1. Trends in streamflow and load data for 9 River Input Monitoring Program sites and 21 Multi-Agency Nontidal Program sites in the Chesapeake Bay Watershed-Continued

\begin{tabular}{|c|c|c|c|c|c|c|c|c|c|c|c|c|}
\hline \multirow{3}{*}{ Parameter } & \multicolumn{2}{|c|}{ Station } & \multicolumn{10}{|c|}{ Statistics } \\
\hline & \multirow{2}{*}{ Flow } & \multirow{2}{*}{ WQ } & \multirow{2}{*}{ POR } & \multirow{2}{*}{ Test } & \multirow{2}{*}{$\begin{array}{l}\log \\
\text { transformation }\end{array}$} & \multirow{2}{*}{$\mathrm{p}$-value } & \multirow{2}{*}{$\begin{array}{l}\text { Base-median } \\
\text { yields }\end{array}$} & \multirow{2}{*}{$\begin{array}{l}\text { Status-median } \\
\text { yields }\end{array}$} & \multicolumn{2}{|c|}{ Magnitude } & \multirow{2}{*}{$\begin{array}{l}\text { Trend } \\
\text { direction }\end{array}$} & \multirow{2}{*}{$\begin{array}{l}\text { Relative } \\
\text { rank }\end{array}$} \\
\hline & & & & & & & & & Minimum & Maximum & & \\
\hline \multicolumn{13}{|c|}{01634000 - N. Fork Shenandoah River near Strasburg, Va. (map ID site \#21) } \\
\hline Q & 01634000 & 1BNFS010.34 & Jan85-Dec98 & Reg & Y & 0.0003 & - & - & 43 & 220 & UP & - \\
\hline $\mathrm{TN}$ & 01634000 & 1BNFS010.34 & Jan85-Dec98 & Reg & Y & .0001 & 1.55 & 7.48 & 96 & 414 & UP & 28 \\
\hline $\mathrm{TNH}$ & 01634000 & 1BNFS010.34 & Jan85-Dec98 & Reg & $\mathrm{Y}$ & .1249 & - & - & -13 & 218 & NS & - \\
\hline TKN & 01634000 & 1BNFS010.34 & Jan85-Dec98 & Reg & $\mathrm{Y}$ & .563 & - & - & -35 & 123 & NS & - \\
\hline $\mathrm{NOx}$ & 01634000 & 1BNFS010.34 & Jan85-Dec98 & Reg & Y & .0001 & 1.15 & 7.61 & 142 & 660 & UP & 41 \\
\hline TP & 01634000 & 1BNFS010.34 & Jan85-Dec98 & Reg & Y & .0001 & .143 & .540 & 169 & 497 & UP & 53 \\
\hline $\mathrm{DP}$ & 01634000 & 1BNFS010.34 & Jan85-Dec98 & - & - & - & - & - & - & - & - & - \\
\hline DIP & 01634000 & 1BNFS010.34 & Jan85-Dec98 & - & - & - & - & - & - & - & - & - \\
\hline TSS & 01634000 & 1BNFS010.34 & Jan85-Dec98 & Reg & Y & .0107 & 5.19 & 38.7 & 48 & 1676 & NS & 9 \\
\hline \multicolumn{13}{|c|}{01666500 - Robinson River near Locust Dale, Va. (map ID site \#23) } \\
\hline Q & 01666500 & 3-ROB001.90 & Jan85-Dec98 & Reg & Y & .0004 & - & - & 40 & 202 & UP & - \\
\hline $\mathrm{TN}$ & 01666500 & 3-ROB001.90 & Jan85-Dec98 & Reg & $\mathrm{Y}$ & .22 & 1.45 & 3.11 & -18 & 136 & NS & 8 \\
\hline $\mathrm{TNH}$ & 01666500 & 3-ROB001.90 & Jan85-Dec98 & Reg & $\mathrm{Y}$ & .2349 & - & - & -66 & 30 & NS & - \\
\hline TKN & 01666500 & 3-ROB001.90 & Jan85-Dec98 & Reg & $\mathrm{Y}$ & .4427 & - & - & -33 & 150 & NS & - \\
\hline NOx & 01666500 & 3-ROB001.90 & Jan85-Dec98 & Reg & $\mathrm{Y}$ & .0583 & 1.16 & 2.79 & -1 & 134 & NS & 14 \\
\hline TP & 01666500 & 3-ROB001.90 & Jan85-Dec98 & Reg & $Y$ & .0014 & .191 & .505 & 39 & 283 & UP & 49 \\
\hline DP & 01666500 & 3-ROB001.90 & Jan85-Dec98 & - & - & - & - & - & - & - & - & - \\
\hline DIP & 01666500 & 3-ROB001.90 & Jan85-Dec98 & - & - & - & - & - & - & - & - & - \\
\hline TSS & 01666500 & 3-ROB001.90 & Jan85-Dec98 & Reg & $\mathrm{Y}$ & .0014 & 12.4 & 95.3 & & & UP & 47 \\
\hline \multicolumn{13}{|c|}{01671020 - North Anna River at Hart Corner near Doswell, Va. (map ID site \#26) } \\
\hline Q & 01671020 & 8-NAR005.42 & Jan85-Dec98 & Reg & $\mathrm{Y}$ & .0456 & - & - & 1 & 129 & NS & - \\
\hline TN & 01671020 & 8-NAR005.42 & Jan85-Dec98 & Reg & Y & .4572 & .434 & 1.34 & -2 & 515 & NS & 0 \\
\hline $\mathrm{TNH}$ & 01671020 & 8-NAR005.42 & Jan85-Dec98 & Reg & $\mathrm{Y}$ & .4189 & - & - & -29 & 126 & NS & - \\
\hline TKN & 01671020 & 8-NAR005.42 & Jan85-Dec98 & Reg & $\mathrm{Y}$ & .7159 & - & - & -43 & 47 & NS & - \\
\hline NOx & 01671020 & 8-NAR005.42 & Jan85-Dec98 & Reg & $Y$ & .1975 & .243 & .623 & -18 & 162 & NS & 1 \\
\hline TP & 01671020 & 8-NAR005.42 & Jan85-Dec98 & Reg & Y & .661 & .178 & .205 & -43 & 43 & NS & 11 \\
\hline DP & 01671020 & 8-NAR005.42 & Jan85-Dec98 & - & - & - & - & - & - & - & - & - \\
\hline DIP & 01671020 & 8-NAR005.42 & Jan85-Dec98 & - & - & - & - & - & - & - & - & - \\
\hline TSS & 01671020 & 8-NAR005.42 & Jan85-Dec98 & Reg & $\mathrm{Y}$ & .0573 & 5.77 & 22.8 & -2 & 515 & NS & 0 \\
\hline
\end{tabular}


Appendix 1. Trends in streamflow and load data for 9 River Input Monitoring Program sites and 21 Multi-Agency Nontidal Program sites in the Chesapeake Bay Watershed-Continued

\begin{tabular}{|c|c|c|c|c|c|c|c|c|c|c|c|c|}
\hline \multirow{3}{*}{ Parameter } & \multicolumn{2}{|c|}{ Station } & \multicolumn{10}{|c|}{ Statistics } \\
\hline & \multirow{2}{*}{ Flow } & \multirow{2}{*}{ WQ } & \multirow{2}{*}{ POR } & \multirow{2}{*}{ Test } & \multirow{2}{*}{$\begin{array}{l}\log \\
\text { transformation }\end{array}$} & \multirow{2}{*}{$p$-value } & \multirow{2}{*}{$\begin{array}{l}\text { Base-median } \\
\text { yields }\end{array}$} & \multirow{2}{*}{$\begin{array}{c}\text { Status-median } \\
\text { yields }\end{array}$} & \multicolumn{2}{|c|}{ Magnitude } & \multirow{2}{*}{$\begin{array}{l}\text { Trend } \\
\text { direction }\end{array}$} & \multirow{2}{*}{$\begin{array}{c}\text { Relative } \\
\text { rank }\end{array}$} \\
\hline & & & & & & & & & Minimum & Maximum & & \\
\hline \multicolumn{13}{|c|}{02013100 - Jackson River below Dunlap Creek at Covington, Va. (map ID site \#28) } \\
\hline Q & 02013100 & 2-JKS023.61 & Jan85-Dec98 & Reg & Y & 0.1632 & - & - & -8 & 61 & NS & - \\
\hline $\mathrm{TN}$ & 02013100 & 2-JKS023.61 & Jan85-Dec98 & Reg & $Y$ & .4438 & 0.916 & 1.36 & -15 & 45 & NS & 0 \\
\hline $\mathrm{TNH}$ & 02013100 & 2-JKS023.61 & Jan85-Dec98 & Reg & Y & .0073 & - & - & 9 & 71 & UP & - \\
\hline TKN & 02013100 & 2-JKS023.61 & Jan85-Dec98 & Reg & $Y$ & .0659 & - & - & -35 & 1 & NS & - \\
\hline NOx & 02013100 & 2-JKS023.61 & Jan85-Dec98 & Reg & $Y$ & .0466 & .257 & .815 & 1 & 127 & NS & 2 \\
\hline TP & 02013100 & 2-JKS023.61 & Jan85-Dec98 & Reg & $\mathrm{Y}$ & .0001 & 5.18 & 1.16 & -83 & -85 & DN & 100 \\
\hline $\mathrm{DP}$ & 02013100 & 2-JKS023.61 & Jan85-Dec98 & - & - & - & - & - & - & - & - & - \\
\hline DIP & 02013100 & 2-JKS023.61 & Jan85-Dec98 & - & - & - & - & - & - & - & - & - \\
\hline TSS & 02013100 & 2-JKS023.61 & Jan85-Dec98 & Reg & $\mathrm{Y}$ & .1306 & 13.2 & 24.5 & -9 & 113 & NS & 0 \\
\hline
\end{tabular}




\section{APPENDIX 2-TRENDS IN FLOW-WEIGHTED CONCENTRATION DATA FOR 9 RIVER INPUT MONITORING PROGRAM SITES AND 21 Multi-Agency Nontidal Program Sites in the Chesapeake Bay Watershed}

Parameters: TN, total nitrogen; DNH, dissolved ammonia; TNH, total ammonia; NOx, total or dissolved nitrate, or, nitrite plus nitrate; DKN, dissolved ammonia plus organic nitrogen; TKN, total ammonia plus organic nitrogen; TP, total phosphorus; DP, dissolved phosphorus; DIP, dissolved inorganic phosphorus; TSS, total suspended solids; SED, suspended sediment.

Station: flow, USGS discharge site number; WQ, water-quality site number.

Statistics: POR, time period used in test; test, regression (Reg), Kendall Theil (KT); log transformed; yes (Y) or no $(\mathrm{N})$; p-value, measure of significance of regressor at 0.01; slope, regression slope; base median, median of first 2 years of record; status median, median of last 3 years of record; magnitude, minimum (min) and maximum (max) percentage change in trend for indicated period of record; tend direction, UP, down (DN), or not significant (NS); relative rank, each individual status concentration (milligrams per liter) compared to all others of the same parameter; shaded areas are significant at 99-percent confidence level; - , not applicable or insufficient data. 
Appendix 2. Trends in flow-weighted concentration data for 9 River Input Monitoring Program sites and 21 Multi-Agency Nontidal Program sites in the Chesapeake Bay Watershed-Continued

\begin{tabular}{|c|c|c|c|c|c|c|c|c|c|c|c|c|}
\hline \multirow{3}{*}{ Parameter } & \multicolumn{2}{|c|}{ Station } & \multicolumn{10}{|c|}{ Statistics } \\
\hline & \multirow{2}{*}{ Flow } & \multirow{2}{*}{$W Q$} & \multirow{2}{*}{ POR } & \multirow{2}{*}{ Test } & \multirow{2}{*}{$\begin{array}{c}\log \\
\text { transformation }\end{array}$} & \multirow{2}{*}{$p$-value } & \multirow{2}{*}{$\begin{array}{l}\text { Base-median } \\
\text { concentration }\end{array}$} & \multirow{2}{*}{$\begin{array}{l}\text { Status-median } \\
\text { concentration }\end{array}$} & \multicolumn{2}{|c|}{ Magnitude } & \multirow{2}{*}{$\begin{array}{c}\text { Trend } \\
\text { direction }\end{array}$} & \multirow{2}{*}{$\begin{array}{c}\text { Relative } \\
\text { rank }\end{array}$} \\
\hline & & & & & & & & & Minimum & Maximum & & \\
\hline
\end{tabular}

\section{RIVER INPUT SITE DATA}

01491000 - Choptank River near Greensboro, Md. (map ID site \#9)

\begin{tabular}{|c|c|c|c|c|c|c|c|c|c|c|c|c|}
\hline TN & 01491000 & 01491000 & Jan85-Dec98 & KT & $\mathrm{Y}$ & 0.0001 & 1.72 & 1.56 & -6 & -9 & $\mathrm{DN}$ & 28 \\
\hline NOx & 01491000 & 01491000 & Jan85-Dec98 & Reg & $\mathrm{N}$ & .5678 & 1.01 & .965 & -6 & 11 & NS & 26 \\
\hline TKN & 01491000 & 01491000 & Jan85-Dec98 & Reg & $Y$ & .0001 & - & - & -29 & -45 & DN & - \\
\hline TP & 01491000 & 01491000 & Jan85-Dec98 & Reg & $\mathrm{Y}$ & .1702 & .056 & .057 & -26 & 5 & NS & 15 \\
\hline DP & 01491000 & 01491000 & Jan85-Dec98 & Reg & $\mathrm{Y}$ & .0001 & .019 & .029 & 27 & 75 & UP & 30 \\
\hline DIP & 01491000 & 01491000 & Jan85-Dec98 & Reg & Y & .0001 & .014 & .024 & 42 & 91 & UP & 34 \\
\hline SED & 01491000 & 01491000 & Jan85-Dec98 & Reg & $Y$ & .0784 & 6.02 & 9.02 & -48 & 3 & NS & 0 \\
\hline
\end{tabular}

\begin{tabular}{|c|c|c|c|c|c|c|c|c|c|c|c|c|}
\hline \multicolumn{13}{|c|}{01578310 - Susquehanna River at Conowingo, Md. (map ID site \#8) } \\
\hline $\mathrm{TN}$ & 01578310 & 01578310 & Jan85-Dec98 & Reg & $\mathrm{N}$ & .0001 & 1.93 & 1.62 & -19 & -21 & DN & 29 \\
\hline NOx & 01578310 & 01578310 & Jan85-Dec98 & Reg & $\mathrm{N}$ & .0454 & 1.19 & 1.21 & 1 & 7 & NS & 34 \\
\hline TKN & 01578310 & 01578310 & Jan85-Dec98 & Reg & $\mathrm{Y}$ & .0001 & - & - & -52 & -58 & DN & - \\
\hline TP & 01578310 & 01578310 & Jan85-Dec98 & KT & $Y$ & .0001 & .060 & .032 & -57 & -75 & DN & 1 \\
\hline DP & 01578310 & 01578310 & Jan85-Dec98 & Reg & $Y$ & .0001 & .024 & .012 & -53 & -61 & DN & 3 \\
\hline DIP & 01578310 & 01578310 & Jan85-Dec98 & Reg & $\mathrm{N}$ & .6223 & .009 & .009 & -14 & 18 & NS & 4 \\
\hline SED & 01578310 & 01578310 & Jan85-Dec98 & Reg & $\mathrm{Y}$ & .1155 & 13.4 & 13.6 & -6 & 73 & NS & 4 \\
\hline \multicolumn{13}{|c|}{01594440 - Patuxent River near Bowie, Md. (map ID site \#11) } \\
\hline $\mathrm{TN}$ & 01594440 & 01594440 & Jan85-Dec98 & Reg & Y & .0001 & 4.76 & 1.77 & -63 & -68 & DN & 34 \\
\hline NOx & 01594440 & 01594440 & Jan85-Dec98 & Reg & $\mathrm{Y}$ & .0001 & 3.24 & 1.21 & -61 & -68 & DN & 34 \\
\hline TKN & 01594440 & 01594440 & Jan85-Dec98 & Reg & $\mathrm{Y}$ & .0001 & - & - & -67 & -70 & DN & - \\
\hline $\mathrm{TP}$ & 01594440 & 01594440 & Jan85-Dec98 & Reg & $\mathrm{Y}$ & .0001 & .329 & .114 & -72 & -76 & $\mathrm{DN}$ & 46 \\
\hline DP & 01594440 & 01594440 & Jan85-Dec98 & Reg & $\mathrm{Y}$ & .0001 & .143 & .041 & -72 & -78 & $\mathrm{DN}$ & 50 \\
\hline DIP & 01594440 & 01594440 & Jan85-Dec98 & Reg & $\mathrm{Y}$ & .0001 & .105 & .042 & -50 & -65 & DN & 72 \\
\hline SED & 01594440 & 01594440 & Jan85-Dec98 & Reg & $\mathrm{Y}$ & .0001 & 45.6 & 38.0 & -31 & -65 & $\mathrm{DN}$ & 45 \\
\hline
\end{tabular}


Appendix 2. Trends in flow-weighted concentration data for 9 River Input Monitoring Program sites and 21 Multi-Agency Nontidal Program sites in the Chesapeake Bay Watershed-Continued

\begin{tabular}{|c|c|c|c|c|c|c|c|c|c|c|c|c|}
\hline \multirow{3}{*}{ Parameter } & \multicolumn{2}{|c|}{ Station } & \multicolumn{10}{|c|}{ Statistics } \\
\hline & \multirow{2}{*}{ Flow } & \multirow{2}{*}{$W Q$} & \multirow{2}{*}{ POR } & \multirow{2}{*}{ Test } & \multirow{2}{*}{$\begin{array}{c}\log \\
\text { transformation }\end{array}$} & \multirow{2}{*}{$p$-value } & \multirow{2}{*}{$\begin{array}{l}\text { Base-median } \\
\text { concentration }\end{array}$} & \multirow{2}{*}{$\begin{array}{l}\text { Status-median } \\
\text { concentration }\end{array}$} & \multicolumn{2}{|c|}{ Magnitude } & \multirow{2}{*}{$\begin{array}{c}\text { Trend } \\
\text { direction }\end{array}$} & \multirow{2}{*}{$\begin{array}{c}\text { Relative } \\
\text { rank }\end{array}$} \\
\hline & & & & & & & & & Minimum & Maximum & & \\
\hline
\end{tabular}

01646580 - Potomac River at Chain Bridge, Md. (map ID site \#28)

\begin{tabular}{|c|c|c|c|c|c|c|c|c|c|c|c|c|}
\hline $\mathrm{TN}$ & 01646580 & PR01 & Jan85-Dec98 & Reg & $Y$ & 0.2125 & 1.79 & 2.09 & -4 & 18 & NS & 42 \\
\hline NOx & 01646580 & PR01 & Jan85-Dec98 & Reg & $\mathrm{N}$ & .0001 & .978 & 1.48 & 28 & 58 & UP & 42 \\
\hline TKN & 01646580 & PR01 & Jan85-Dec98 & Reg & $Y$ & .0036 & - & - & -9 & -38 & NS & - \\
\hline TP & 01646580 & PR01 & Jan85-Dec98 & Reg & $\mathrm{Y}$ & .6033 & .099 & .100 & -33 & 26 & NS & 38 \\
\hline DP & 01646580 & PR01 & Jan85-Dec98 & Reg & $\mathrm{Y}$ & .0001 & .054 & .041 & -22 & -45 & DN & 50 \\
\hline DIP & 01646580 & PR01 & Jan85-Dec98 & Reg & $\mathrm{Y}$ & .0165 & .030 & .025 & -32 & -4 & NS & 38 \\
\hline SED & 01646580 & PR01 & Jan85-Dec98 & Reg & $\mathrm{Y}$ & .0080 & 32.3 & 34.8 & -19 & -74 & DN & 39 \\
\hline
\end{tabular}

01668000 - Rappahannock River near Fredericksburg, Va. (map ID site \#24)

\begin{tabular}{|c|c|c|c|c|c|c|c|c|c|c|c|c|}
\hline TSS & 01668000 & 01668000 & Jan88-Dec98 & Reg & $\mathrm{Y}$ & .8476 & 25.8 & 41.6 & -67 & 150 & NS & 100 \\
\hline TN & 01668000 & 01668000 & Jan88-Dec98 & Reg & Y & .0934 & .959 & .999 & -38 & 4 & NS & 14 \\
\hline NOx & 01668000 & 01668000 & Jan88-Dec98 & Reg & $\mathrm{N}$ & .0570 & .544 & .498 & -36 & 1 & NS & 29 \\
\hline TP & 01668000 & 01668000 & Jan88-Dec98 & Reg & $\mathrm{Y}$ & .4219 & .068 & .080 & -54 & 38 & NS & 11 \\
\hline DIP & 01668000 & 01668000 & Jan88-Dec98 & Reg & $\mathrm{Y}$ & .9006 & .012 & .014 & -21 & 23 & NS & 13 \\
\hline \multicolumn{13}{|c|}{01673000 - Pamunkey River near Hanover, Va. (map ID site \#25) } \\
\hline TSS & 01673000 & 01673000 & Jan89-Dec98 & Reg & Y & .2302 & 28.9 & 25.4 & -60 & 25 & NS & 55 \\
\hline TN & 01673000 & 01673000 & Jan89-Dec98 & Reg & Y & .5426 & .740 & .697 & -8 & 5 & NS & 6 \\
\hline NOx & 01673000 & 01673000 & Jan89-Dec98 & Reg & $\mathrm{N}$ & .0001 & .236 & .305 & 26 & 38 & UP & 13 \\
\hline TP & 01673000 & 01673000 & Jan89-Dec98 & Reg & $\mathrm{Y}$ & .5659 & .075 & .067 & -13 & 8 & NS & 5 \\
\hline DIP & 01673000 & 01673000 & Jan89-Dec98 & Reg & $\mathrm{Y}$ & .0001 & .016 & .025 & 74 & 125 & UP & 38 \\
\hline \multicolumn{13}{|c|}{01674500 - Mattaponi River near Beulahville, Va. (map ID site \#27) } \\
\hline TSS & 01674500 & 01674500 & Jan89-Dec98 & Reg & $\mathrm{N}$ & .7662 & 8.10 & 9.69 & -22 & 29 & NS & 5 \\
\hline TN & 01674500 & 01674500 & Jan89-Dec98 & Reg & $\mathrm{Y}$ & .0001 & .841 & .521 & -22 & -34 & DN & 1 \\
\hline NOx & 01674500 & 01674500 & Jan89-Dec98 & Reg & $\mathrm{N}$ & .0001 & .201 & .127 & -28 & -41 & DN & 0 \\
\hline TP & 01674500 & 01674500 & Jan89-Dec98 & KT & $\mathrm{N}$ & .0001 & .082 & .045 & -31 & -45 & DN & 0 \\
\hline DIP & 01674500 & 01674500 & Jan89-Dec98 & Reg & $\mathrm{N}$ & .0001 & .020 & .017 & 23 & 39 & UP & 21 \\
\hline
\end{tabular}


Appendix 2. Trends in flow-weighted concentration data for 9 River Input Monitoring Program sites and 21 Multi-Agency Nontidal Program sites in the Chesapeake Bay Watershed-Continued

\begin{tabular}{|c|c|c|c|c|c|c|c|c|c|c|c|c|}
\hline \multirow{3}{*}{ Parameter } & \multicolumn{2}{|c|}{ Station } & \multicolumn{10}{|c|}{ Statistics } \\
\hline & \multirow{2}{*}{ Flow } & \multirow{2}{*}{ WQ } & \multirow{2}{*}{ POR } & \multirow{2}{*}{ Test } & \multirow{2}{*}{$\begin{array}{c}\stackrel{\log }{\text { transformation }}\end{array}$} & \multirow{2}{*}{ p-value } & \multirow{2}{*}{$\begin{array}{l}\text { Base-median } \\
\text { concentration }\end{array}$} & \multirow{2}{*}{$\begin{array}{l}\text { Status-median } \\
\text { concentration }\end{array}$} & \multicolumn{2}{|c|}{ Magnitude } & \multirow{2}{*}{$\begin{array}{l}\text { Trend } \\
\text { direction }\end{array}$} & \multirow{2}{*}{$\begin{array}{l}\text { Relative } \\
\text { rank }\end{array}$} \\
\hline & & & & & & & & & Minimum & Maximum & & \\
\hline \multicolumn{13}{|c|}{02035000 - James River at Cartersville, Va. (map ID site \#29) } \\
\hline TSS & 02035000 & 02035000 & Jan88-Dec98 & Reg & Y & 0.6124 & 15.5 & 34.0 & -60 & 72 & NS & 82 \\
\hline TN & 02035000 & 02035000 & Jan88-Dec98 & Reg & $\mathrm{Y}$ & .0169 & .624 & .587 & -34 & -4 & NS & 3 \\
\hline NOx & 02035000 & 02035000 & Jan88-Dec98 & Reg & Y & .0031 & .239 & .227 & -12 & -45 & DN & 7 \\
\hline $\mathrm{TP}$ & 02035000 & 02035000 & Jan88-Dec98 & $\mathrm{KT}$ & $\mathrm{N}$ & .0000 & .154 & .088 & -48 & -61 & DN & 3 \\
\hline DIP & 02035000 & 02035000 & Jan88-Dec98 & Reg & $Y$ & .0001 & .098 & .035 & -60 & -72 & DN & 58 \\
\hline \multicolumn{13}{|c|}{02041650 - Appomattox River at Matoaca, Va. (map ID site \#30) } \\
\hline TSS & 02041650 & 02041650 & Jan89-Dec98 & Reg & $\mathrm{Y}$ & .6085 & 9.19 & 9.18 & -38 & 32 & NS & 3 \\
\hline TN & 02041650 & 02041650 & Jan89-Dec98 & Reg & Y & .0001 & .594 & .500 & -14 & -22 & DN & 1 \\
\hline NOx & 02041650 & 02041650 & Jan89-Dec98 & Reg & Y & .0817 & .171 & .162 & -16 & 1 & NS & 2 \\
\hline $\mathrm{TP}$ & 02041650 & 02041650 & Jan89-Dec98 & Reg & $Y$ & .6620 & .043 & .046 & -18 & 13 & NS & 1 \\
\hline DIP & 02041650 & 02041650 & Jan89-Dec98 & Reg & $\mathrm{N}$ & .0001 & .011 & .013 & 20 & 29 & UP & 12 \\
\hline
\end{tabular}

\section{MULTI-AGENCY SITE DATA}

01531500 - Susquehanna River at Towanda, Pa. (map ID site \#1)

\begin{tabular}{|c|c|c|c|c|c|c|c|c|c|c|c|c|}
\hline TN & 01531500 & TOW & Jan89-Dec98 & Reg & $\mathrm{Y}$ & .1364 & 2.45 & .965 & -68 & 16 & NS & 13 \\
\hline NOx & 01531500 & TOW & Jan89-Dec98 & Reg & $Y$ & .0858 & 1.55 & .531 & -70 & 8 & NS & 12 \\
\hline TP & 01531500 & TOW & Jan89-Dec98 & Reg & $\mathrm{Y}$ & .0551 & .135 & .050 & -76 & 1 & NS & 11 \\
\hline DP & 01531500 & TOW & Jan89-Dec98 & Reg & $Y$ & .0026 & .062 & .019 & -30 & -80 & $\mathrm{DN}$ & 14 \\
\hline DIP & 01531500 & TOW & Jan89-Dec98 & Reg & $Y$ & .1012 & .020 & .007 & -68 & 10 & NS & 0 \\
\hline SED & 01531500 & TOW & Jan89-Dec98 & Reg & $Y$ & .2516 & 137 & 46.0 & -79 & 50 & NS & 58 \\
\hline
\end{tabular}

01540500 - Susquehanna River at Danville, Pa. (map ID site \#2)

\begin{tabular}{|c|c|c|c|c|c|c|c|c|c|c|c|c|}
\hline $\mathrm{TN}$ & 01540500 & DAN & Jan85-Dec98 & Reg & $\mathrm{Y}$ & .0870 & 2.00 & 1.16 & -60 & 6 & NS & 18 \\
\hline NOx & 01540500 & DAN & Jan85-Dec98 & Reg & $\mathrm{Y}$ & .5176 & 1.08 & .707 & -47 & 37 & NS & 18 \\
\hline TP & 01540500 & DAN & Jan85-Dec98 & Reg & $Y$ & .0082 & .117 & .053 & -18 & -73 & DN & 13 \\
\hline DP & 01540500 & DAN & Jan85-Dec98 & Reg & $\mathrm{Y}$ & .0001 & .038 & .013 & -46 & -80 & DN & 3 \\
\hline DIP & 01540500 & DAN & Jan85-Dec98 & Reg & $Y$ & .0245 & .019 & .008 & -68 & -8 & NS & 0 \\
\hline SED & 01540500 & DAN & Jan85-Dec98 & Reg & $Y$ & .2094 & 82.4 & 27.7 & -74 & 34 & NS & 28 \\
\hline
\end{tabular}


Appendix 2. Trends in flow-weighted concentration data for 9 River Input Monitoring Program sites and 21 Multi-Agency Nontidal Program sites in the Chesapeake Bay Watershed-Continued

\begin{tabular}{|c|c|c|c|c|c|c|c|c|c|c|c|c|}
\hline \multirow{3}{*}{ Parameter } & \multicolumn{2}{|c|}{ Station } & \multicolumn{10}{|c|}{ Statistics } \\
\hline & \multirow{2}{*}{ Flow } & \multirow{2}{*}{$W Q$} & \multirow{2}{*}{ POR } & \multirow{2}{*}{ Test } & \multirow{2}{*}{$\begin{array}{c}\log \\
\text { transformation }\end{array}$} & \multirow{2}{*}{$p$-value } & \multirow{2}{*}{$\begin{array}{l}\text { Base-median } \\
\text { concentration }\end{array}$} & \multirow{2}{*}{$\begin{array}{l}\text { Status-median } \\
\text { concentration }\end{array}$} & \multicolumn{2}{|c|}{ Magnitude } & \multirow{2}{*}{$\begin{array}{c}\text { Trend } \\
\text { direction }\end{array}$} & \multirow{2}{*}{$\begin{array}{c}\text { Relative } \\
\text { rank }\end{array}$} \\
\hline & & & & & & & & & Minimum & Maximum & & \\
\hline
\end{tabular}

01553500 - West Branch Susquehanna River at Lewisburg, Pa. (map ID site \#3)

\begin{tabular}{|c|c|c|c|c|c|c|c|c|c|c|c|c|}
\hline $\mathrm{TN}$ & 01553500 & LEW & Jan85-Dec98 & Reg & $Y$ & 0.0608 & 1.16 & 0.99 & -59 & 2 & NS & 13 \\
\hline NOx & 01553500 & LEW & Jan85-Dec98 & Reg & $\mathrm{Y}$ & .3050 & .612 & .562 & -48 & 23 & NS & 13 \\
\hline TP & 01553500 & LEW & Jan85-Dec98 & Reg & Y & .0007 & .047 & .026 & -34 & -77 & DN & 0 \\
\hline DP & 01553500 & LEW & Jan85-Dec98 & Reg & $\mathrm{Y}$ & .0001 & .025 & .010 & -54 & -81 & $\mathrm{DN}$ & 0 \\
\hline DIP & 01553500 & LEW & Jan85-Dec98 & Reg & $\mathrm{Y}$ & .0670 & .011 & .007 & -58 & 3 & NS & 0 \\
\hline SED & 01553500 & LEW & Jan85-Dec98 & Reg & $Y$ & .5425 & 25.5 & 15.5 & -67 & 79 & NS & 7 \\
\hline
\end{tabular}

01567000 - Juniata River at Newport, Pa. (map ID site \#4)

\begin{tabular}{|c|c|c|c|c|c|c|c|c|c|c|c|c|}
\hline $\mathrm{TN}$ & 01567000 & JUN & Jan85-Dec98 & Reg & Y & .1431 & 1.94 & 1.18 & -56 & 12 & NS & 18 \\
\hline NOx & 01567000 & JUN & Jan85-Dec98 & Reg & $\mathrm{Y}$ & .3235 & 1.24 & .911 & -50 & 26 & NS & 24 \\
\hline TP & 01567000 & JUN & Jan85-Dec98 & Reg & Y & .0003 & .078 & .036 & -36 & -77 & DN & 3 \\
\hline DP & 01567000 & JUN & Jan85-Dec98 & Reg & Y & .0001 & .046 & .018 & -47 & -78 & DN & 12 \\
\hline DIP & 01567000 & JUN & Jan85-Dec98 & Reg & Y & .0001 & .042 & .014 & -42 & -79 & DN & 14 \\
\hline SED & 01567000 & JUN & Jan85-Dec98 & Reg & $Y$ & .5377 & 40.2 & 28.3 & -64 & 69 & NS & 29 \\
\hline
\end{tabular}

01576000 - Susquehanna River at Marietta, Pa. (map ID site \#6)

\begin{tabular}{|c|c|c|c|c|c|c|c|c|c|c|c|c|}
\hline $\mathrm{TN}$ & 01576000 & MAR & Jan85-Dec98 & Reg & $\mathrm{Y}$ & .0794 & 2.15 & 1.04 & -61 & 5 & NS & 15 \\
\hline NOx & 01576000 & MAR & Jan85-Dec98 & Reg & $\mathrm{Y}$ & .2664 & 1.29 & .813 & -54 & 25 & NS & 21 \\
\hline TP & 01576000 & MAR & Jan85-Dec98 & Reg & $Y$ & .0186 & .084 & .035 & -73 & -12 & NS & 3 \\
\hline DP & 01576000 & MAR & Jan85-Dec98 & Reg & $\mathrm{Y}$ & .0001 & .040 & .014 & -38 & -76 & DN & 6 \\
\hline DIP & 01576000 & MAR & Jan85-Dec98 & Reg & $Y$ & .2360 & .008 & .008 & -19 & 130 & NS & 1 \\
\hline SED & 01576000 & MAR & Jan85-Dec98 & Reg & $\mathrm{Y}$ & .2564 & 35.1 & 23.0 & -74 & 43 & NS & 20 \\
\hline
\end{tabular}

01576754 - Conestoga River at Conestoga, Pa. (map ID site \#7)

\begin{tabular}{|c|c|c|c|c|c|c|c|c|c|c|c|c|}
\hline TN & 01576754 & CON & Jan85-Dec98 & Reg & $Y$ & .2686 & 10.1 & 5.76 & -39 & 15 & NS & 100 \\
\hline NOx & 01576754 & $\mathrm{CON}$ & Jan85-Dec98 & Reg & $Y$ & .3912 & 7.14 & 4.67 & -35 & 8 & NS & 100 \\
\hline TP & 01576754 & CON & Jan85-Dec98 & Reg & $Y$ & .0013 & .690 & .237 & -27 & -71 & DN & 100 \\
\hline DP & 01576754 & CON & Jan85-Dec98 & Reg & $Y$ & .0001 & .343 & .101 & -52 & -77 & DN & 100 \\
\hline DIP & 01576754 & CON & Jan85-Dec98 & Reg & Y & .0001 & .321 & .095 & -52 & -77 & DN & 100 \\
\hline SED & 01576754 & $\mathrm{CON}$ & Jan85-Dec98 & Reg & $Y$ & .1896 & 124 & 92.1 & -72 & 28 & NS & 100 \\
\hline
\end{tabular}


Appendix 2. Trends in flow-weighted concentration data for 9 River Input Monitoring Program sites and 21 Multi-Agency Nontidal Program sites in the Chesapeake Bay Watershed-Continued

\begin{tabular}{|c|c|c|c|c|c|c|c|c|c|c|c|c|}
\hline \multirow{3}{*}{ Parameter } & \multicolumn{2}{|c|}{ Station } & \multicolumn{10}{|c|}{ Statistics } \\
\hline & \multirow{2}{*}{ Flow } & \multirow{2}{*}{ WQ } & \multirow{2}{*}{ POR } & \multirow{2}{*}{ Test } & \multirow{2}{*}{$\begin{array}{c}\quad \log \\
\text { transformation }\end{array}$} & \multirow{2}{*}{ p-value } & \multirow{2}{*}{$\begin{array}{l}\text { Base-median } \\
\text { concentration }\end{array}$} & \multirow{2}{*}{$\begin{array}{l}\text { Status-median } \\
\text { concentration }\end{array}$} & \multicolumn{2}{|c|}{ Magnitude } & \multirow{2}{*}{$\begin{array}{l}\text { Trend } \\
\text { direction }\end{array}$} & \multirow{2}{*}{$\begin{array}{c}\text { Relative } \\
\text { rank }\end{array}$} \\
\hline & & & & & & & & & Minimum & Maximum & & \\
\hline \multicolumn{13}{|c|}{01570000 - Conodoguinet Creek near Hogestown, Pa. (map ID site \#5) } \\
\hline TN & 01570000 & WQN0213 & Jan85-Dec98 & Reg & $\mathrm{N}$ & 0.5412 & 2.38 & 2.65 & -36 & 68 & NS & 56 \\
\hline NOx & 01570000 & WQN0213 & Jan85-Dec98 & - & - & - & - & - & - & - & - & - \\
\hline TP & 01570000 & WQN0213 & Jan85-Dec98 & Reg & Y & .0045 & .078 & .028 & -34 & -88 & DN & 0 \\
\hline DP & 01570000 & WQN0213 & Jan85-Dec98 & Reg & $\mathrm{Y}$ & .0001 & .046 & .012 & -72 & -93 & DN & 1 \\
\hline DIP & 01570000 & WQN0213 & Jan85-Dec98 & Reg & $\mathrm{N}$ & .0001 & .104 & .009 & -69 & -79 & DN & 4 \\
\hline TSS & 01570000 & WQN0213 & Jan85-Dec98 & - & - & - & - & - & - & - & - & - \\
\hline \multicolumn{13}{|c|}{01586000 - North Branch Patapsco River at Cedarhurst, Md. (map ID site \#12) } \\
\hline TN & 01586000 & NPA0165 & Jan85-Dec98 & Reg & Y & .2419 & 3.57 & 4.51 & 25 & 38 & NS & 100 \\
\hline NOx & 01586000 & NPA0165 & Jan85-Dec98 & Reg & $\mathrm{N}$ & .0001 & 2.96 & 3.37 & 10 & 25 & UP & 100 \\
\hline TP & 01586000 & NPA0165 & Jan85-Dec98 & Reg & $\mathrm{Y}$ & .143 & .066 & .047 & -67 & 17 & NS & 9 \\
\hline DP & 01586000 & NPA0165 & Jan85-Dec98 & - & - & - & - & - & - & - & - & - \\
\hline DIP & 01586000 & NPA0165 & Jan85-Dec98 & - & - & - & - & - & - & - & - & - \\
\hline TSS & 01586000 & NPA0165 & Jan85-Dec98 & Reg & $\mathrm{Y}$ & .2419 & 10.2 & 17.7 & -31 & - & NS & 31 \\
\hline \multicolumn{13}{|c|}{01592500 - Patuxent River near Laurel, Md. (map ID site \#10) } \\
\hline TN & 01592500 & РХT0809 & Jan85-Dec98 & Reg & $\mathrm{N}$ & .0001 & 1.55 & 1.92 & 18 & 26 & UP & 37 \\
\hline NOx & 01592500 & РXT0809 & Jan85-Dec98 & Reg & $\mathrm{N}$ & .0001 & .942 & 1.15 & 16 & 27 & UP & 32 \\
\hline TP & 01592500 & PXT0809 & Jan85-Dec98 & Reg & $\mathrm{N}$ & .0001 & .045 & .043 & -4 & -8 & DN & 7 \\
\hline DP & 01592500 & PXT0809 & Jan85-Dec98 & - & - & - & - & - & - & - & - & - \\
\hline DIP & 01592500 & РXT0809 & Jan85-Dec98 & - & - & - & - & - & - & - & - & - \\
\hline TSS & 01592500 & PXT0809 & Jan85-Dec98 & Reg & Y & .0001 & 6.88 & 12.0 & 87 & 94 & UP & 12 \\
\hline \multicolumn{13}{|c|}{01599000 - Georges Creek near Franklin, Md. (map ID site \#13) } \\
\hline TN & 01599000 & GEO0009 & Jan85-Dec98 & Reg & $\mathrm{N}$ & .0001 & 2.00 & 1.37 & -31 & -35 & DN & 23 \\
\hline NOx & 01599000 & GEO0009 & Jan85-Dec98 & - & - & - & - & - & - & - & - & - \\
\hline TP & 01599000 & GEO0009 & Jan85-Dec98 & Reg & $\mathrm{Y}$ & .0001 & .112 & .063 & -36 & -50 & DN & 18 \\
\hline DP & 01599000 & GEO0009 & Jan85-Dec98 & - & - & - & - & - & - & - & - & - \\
\hline DIP & 01599000 & GEO0009 & Jan85-Dec98 & - & - & - & - & - & - & - & - & - \\
\hline TSS & 01599000 & GEO0009 & Jan85-Dec98 & Reg & $\mathrm{Y}$ & .0012 & 29.9 & 39.1 & 13 & 61 & UP & 99 \\
\hline
\end{tabular}


Appendix 2. Trends in flow-weighted concentration data for 9 River Input Monitoring Program sites and 21 Multi-Agency Nontidal Program sites in the Chesapeake Bay Watershed-Continued

\begin{tabular}{|c|c|c|c|c|c|c|c|c|c|c|c|c|}
\hline \multirow{3}{*}{ Parameter } & \multicolumn{2}{|c|}{ Station } & \multicolumn{10}{|c|}{ Statistics } \\
\hline & \multirow{2}{*}{ Flow } & \multirow{2}{*}{$W Q$} & \multirow{2}{*}{ POR } & \multirow{2}{*}{ Test } & \multirow{2}{*}{$\begin{array}{c}\log \\
\text { transformation }\end{array}$} & \multirow{2}{*}{$p$-value } & \multirow{2}{*}{$\begin{array}{l}\text { Base-median } \\
\text { concentration }\end{array}$} & \multirow{2}{*}{$\begin{array}{l}\text { Status-median } \\
\text { concentration }\end{array}$} & \multicolumn{2}{|c|}{ Magnitude } & \multirow{2}{*}{$\begin{array}{c}\text { Trend } \\
\text { direction }\end{array}$} & \multirow{2}{*}{$\begin{array}{c}\text { Relative } \\
\text { rank }\end{array}$} \\
\hline & & & & & & & & & Minimum & Maximum & & \\
\hline
\end{tabular}

01601500 - Wills Creek near Cumberland, Md. (map ID site \#14)

\begin{tabular}{|c|c|c|c|c|c|c|c|c|c|c|c|c|}
\hline $\mathrm{TN}$ & 01601500 & WIL0013 & Jan85-Dec98 & Reg & $\mathrm{Y}$ & 0.0001 & 1.71 & 1.20 & -28 & -49 & DN & 19 \\
\hline NOx & 01601500 & WIL0013 & Jan85-Dec98 & - & - & - & - & - & - & - & - & - \\
\hline TP & 01601500 & WIL0013 & Jan85-Dec98 & Reg & $N$ & .2579 & .038 & .043 & -22 & 82 & NS & 7 \\
\hline DP & 01601500 & WIL0013 & Jan85-Dec98 & - & - & - & - & - & - & - & - & - \\
\hline DIP & 01601500 & WIL0013 & Jan85-Dec98 & - & - & - & - & - & - & - & - & - \\
\hline TSS & 01601500 & WIL0013 & Jan85-Dec98 & Reg & $\mathrm{Y}$ & .3966 & 14.0 & 18.9 & -22 & 87 & NS & 34 \\
\hline \multicolumn{13}{|c|}{01610000 - Potomac River at Paw Paw, W. Va. (map ID site \#15) } \\
\hline $\mathrm{TN}$ & 01610000 & РОТ2766 & Jan85-Dec98 & Reg & Y & .0001 & 1.17 & 1.08 & -8 & -18 & DN & 16 \\
\hline NOx & 01610000 & РОT2766 & Jan85-Dec98 & - & - & - & - & - & - & - & - & - \\
\hline TP & 01610000 & РОT2766 & Jan85-Dec98 & Reg & Y & .0011 & .078 & .052 & -21 & -52 & $\mathrm{DN}$ & 12 \\
\hline DP & 01610000 & РОТ2766 & Jan85-Dec98 & - & - & - & - & - & - & - & - & - \\
\hline DIP & 01610000 & РОТ2766 & Jan85-Dec98 & - & - & - & - & - & - & - & - & - \\
\hline TSS & 01610000 & РОТ2766 & Jan85-Dec98 & Reg & $\mathrm{Y}$ & .6483 & 13.0 & 19.4 & -46 & 48 & NS & 36 \\
\hline \multicolumn{13}{|c|}{01613000 - Potomac River at Hancock, Md. (map ID site \#16) } \\
\hline $\mathrm{TN}$ & 01613000 & РОТ2386 & Jan85-Dec98 & Reg & Y & .0001 & 1.37 & 1.05 & -30 & -40 & DN & 15 \\
\hline NOx & 01613000 & РОТ2386 & Jan85-Dec98 & Reg & $\mathrm{Y}$ & .0001 & .721 & .565 & -21 & -45 & DN & 13 \\
\hline TP & 01613000 & РОТ2386 & Jan85-Dec98 & Reg & $\mathrm{N}$ & .0001 & .077 & .047 & -18 & -69 & DN & 9 \\
\hline $\mathrm{DP}$ & 01613000 & РОT2386 & Jan85-Dec98 & - & - & - & - & - & - & - & - & - \\
\hline DIP & 01613000 & РОТ2386 & Jan85-Dec98 & - & - & - & - & - & - & - & - & - \\
\hline TSS & 01613000 & РОТ2386 & Jan85-Dec98 & Reg & $\mathrm{Y}$ & .1246 & 12.0 & 22.9 & -12 & 190 & NS & 47 \\
\hline \multicolumn{13}{|c|}{01614500 - Conococheague Creek at Fairview, Md. (map ID site \#17) } \\
\hline $\mathrm{TN}$ & 01614500 & CON0180 & Jan85-Dec98 & Reg & $\mathrm{N}$ & .0001 & 4.72 & 4.16 & -12 & -20 & DN & 95 \\
\hline NOx & 01614500 & CON0180 & Jan85-Dec98 & Reg & $N$ & .0001 & 3.79 & 3.27 & -14 & -26 & DN & 98 \\
\hline TP & 01614500 & CON0180 & Jan85-Dec98 & Reg & $\mathrm{N}$ & .0001 & .182 & .118 & -43 & -62 & DN & 48 \\
\hline DP & 01614500 & CON0180 & Jan85-Dec98 & - & - & - & - & - & - & - & - & - \\
\hline DIP & 01614500 & CON0180 & Jan85-Dec98 & - & - & - & - & - & - & - & - & - \\
\hline TSS & 01614500 & CON0180 & Jan85-Dec98 & Reg & $N$ & .0395 & 13.8 & 26.5 & 7 & 220 & NS & 58 \\
\hline
\end{tabular}


Appendix 2. Trends in flow-weighted concentration data for 9 River Input Monitoring Program sites and 21 Multi-Agency Nontidal Program sites in the Chesapeake Bay Watershed-Continued

\begin{tabular}{|c|c|c|c|c|c|c|c|c|c|c|c|c|}
\hline \multirow{3}{*}{ Parameter } & \multicolumn{2}{|c|}{ Station } & \multicolumn{10}{|c|}{ Statistics } \\
\hline & \multirow{2}{*}{ Flow } & \multirow{2}{*}{ WQ } & \multirow{2}{*}{ POR } & \multirow{2}{*}{ Test } & \multirow{2}{*}{$\begin{array}{l}\text { Log } \\
\text { transformation }\end{array}$} & \multirow{2}{*}{$p$-value } & \multirow{2}{*}{$\begin{array}{l}\text { Base-median } \\
\text { concentration }\end{array}$} & \multirow{2}{*}{$\begin{array}{l}\text { Status-median } \\
\text { concentration }\end{array}$} & \multicolumn{2}{|c|}{ Magnitude } & \multirow{2}{*}{$\begin{array}{l}\text { Trend } \\
\text { direction }\end{array}$} & \multirow{2}{*}{$\begin{array}{l}\text { Relative } \\
\text { rank }\end{array}$} \\
\hline & & & & & & & & & Minimum & Maximum & & \\
\hline \multicolumn{13}{|c|}{01638500 - Potomac River at Point of Rocks, Md. (map ID site \#19) } \\
\hline TN & 01638500 & POT1595 & Jan85-Dec98 & Reg & Y & 0.0001 & 2.14 & 1.89 & -11 & -18 & DN & 37 \\
\hline NOx & 01638500 & РОT1595 & Jan85-Dec98 & Reg & $\mathrm{N}$ & .0061 & 1.28 & 1.22 & -4 & -20 & DN & 34 \\
\hline TP & 01638500 & РОT1595 & Jan85-Dec98 & Reg & $\mathrm{Y}$ & .0012 & .108 & .079 & -16 & -49 & NS & 27 \\
\hline DP & 01638500 & POT1595 & Jan85-Dec98 & - & - & - & - & - & - & - & - & - \\
\hline DIP & 01638500 & POT1595 & Jan85-Dec98 & - & - & - & - & - & - & - & - & - \\
\hline TSS & 01638500 & РОT1595 & Jan85-Dec98 & Reg & $Y$ & .1856 & 13.7 & 32.6 & -17 & 160 & NS & 78 \\
\hline \multicolumn{13}{|c|}{01643000 - Monocacy River at Reels Mill Road, Md. (map ID site \#18) } \\
\hline TN & 01643000 & MON0528 & Jan85-Dec98 & Reg & Y & . 0001 & 2.80 & 1.84 & -37 & -53 & DN & 35 \\
\hline NOx & 01643000 & MON0528 & Jan85-Dec98 & Reg & $\mathrm{N}$ & .0001 & 1.27 & .614 & -37 & -80 & DN & 15 \\
\hline TP & 01643000 & MON0528 & Jan85-Dec98 & Reg & $\mathrm{N}$ & . 0001 & .219 & .126 & -32 & -62 & DN & 52 \\
\hline DP & 01643000 & MON0528 & Jan85-Dec98 & - & - & - & - & - & - & - & - & - \\
\hline DIP & 01643000 & MON0528 & Jan85-Dec98 & - & - & - & - & - & - & - & - & - \\
\hline TSS & 01643000 & MON0528 & Jan85-Dec98 & Reg & $\mathrm{Y}$ & .3846 & 15.6 & 18.8 & -18 & 66 & NS & 34 \\
\hline \multicolumn{13}{|c|}{01631000 - S. Fork Shenandoah River near Front Royal, Va. (map ID site \#20) } \\
\hline TN & 01631000 & 1BSSF003.56 & Jan85-Dec98 & Reg & $\mathrm{Y}$ & . 0001 & 1.23 & 1.09 & -16 & -37 & DN & 16 \\
\hline NOx & 01631000 & 1BSSF003.56 & Jan85-Dec98 & Reg & $\mathrm{Y}$ & .0001 & .758 & 1.21 & 62 & 33 & UP & 34 \\
\hline TP & 01631000 & 1BSSF003.56 & Jan85-Dec98 & Reg & $\mathrm{Y}$ & .0001 & .215 & .182 & -11 & -28 & DN & 83 \\
\hline DP & 01631000 & 1BSSF003.56 & Jan85-Dec98 & - & - & - & - & - & - & - & - & - \\
\hline DIP & 01631000 & 1BSSF003.56 & Jan85-Dec98 & - & - & - & - & - & - & - & - & - \\
\hline TSS & 01631000 & 1BSSF003.56 & Jan85-Dec98 & - & - & - & - & - & - & - & - & - \\
\hline \multicolumn{13}{|c|}{01634000 - N. Fork Shenandoah River near Strasburg, Va. (map ID site \#21) } \\
\hline TN & 01634000 & 1BNFS010.34 & Jan85-Dec98 & Reg & $\mathrm{N}$ & . 0001 & 1.20 & 1.73 & 19 & 52 & UP & 33 \\
\hline NOx & 01634000 & 1BNFS010.34 & Jan85-Dec98 & Reg & $\mathrm{N}$ & . 0001 & .838 & 1.79 & 92 & 153 & UP & 52 \\
\hline TP & 01634000 & 1BNFS010.34 & Jan85-Dec98 & Reg & $\mathrm{Y}$ & .0001 & .116 & .184 & 72 & 104 & UP & 84 \\
\hline DP & 01634000 & 1BNFS010.34 & Jan85-Dec98 & - & - & - & - & - & - & - & - & - \\
\hline DIP & 01634000 & 1BNFS010.34 & Jan85-Dec98 & - & - & - & - & - & - & - & - & - \\
\hline TSS & 01634000 & 1BNFS010.34 & Jan85-Dec98 & Reg & Y & .0466 & 4.24 & 10.1 & 2 & 470 & NS & 6 \\
\hline
\end{tabular}


Appendix 2. Trends in flow-weighted concentration data for 9 River Input Monitoring Program sites and 21 Multi-Agency Nontidal Program sites in the Chesapeake Bay Watershed-Continued

\begin{tabular}{|c|c|c|c|c|c|c|c|c|c|c|c|c|}
\hline \multirow{3}{*}{ Parameter } & \multicolumn{2}{|c|}{ Station } & \multicolumn{10}{|c|}{ Statistics } \\
\hline & \multirow{2}{*}{ Flow } & \multirow{2}{*}{ WQ } & \multirow{2}{*}{ POR } & \multirow{2}{*}{ Test } & \multirow{2}{*}{$\begin{array}{c}\log \\
\text { transformation }\end{array}$} & \multirow{2}{*}{$\mathrm{p}$-value } & \multirow{2}{*}{$\begin{array}{l}\text { Base-median } \\
\text { concentration }\end{array}$} & \multirow{2}{*}{$\begin{array}{l}\text { Status-median } \\
\text { concentration }\end{array}$} & \multicolumn{2}{|c|}{ Magnitude } & \multirow{2}{*}{$\begin{array}{l}\text { Trend } \\
\text { direction }\end{array}$} & \multirow{2}{*}{$\begin{array}{c}\text { Relative } \\
\text { rank }\end{array}$} \\
\hline & & & & & & & & & Minimum & Maximum & & \\
\hline \multicolumn{13}{|c|}{01666500 - Robinson River near Locust Dale, Va. (map ID site \#23) } \\
\hline TN & 01666500 & 3-ROB001.90 & Jan85-Dec98 & Reg & Y & 0.0468 & .675 & .735 & -27 & 0 & NS & 7 \\
\hline NOx & 01666500 & 3-ROB001.90 & Jan85-Dec98 & Reg & Y & .0032 & .560 & .535 & -4 & -16 & DN & 12 \\
\hline TP & 01666500 & 3-ROB001.90 & Jan85-Dec98 & Reg & $\mathrm{Y}$ & .0001 & .093 & .132 & 15 & 54 & UP & 56 \\
\hline DP & 01666500 & 3-ROB001.90 & Jan85-Dec98 & - & - & - & - & - & - & - & - & - \\
\hline DIP & 01666500 & 3-ROB001.90 & Jan85-Dec98 & - & - & - & - & - & - & - & - & - \\
\hline TSS & 01666500 & 3-ROB001.90 & Jan85-Dec98 & Reg & Y & .0071 & 5.56 & 28.4 & 55 & 130 & UP & 65 \\
\hline \multicolumn{13}{|c|}{01671020 - North Anna River at Hart Corner near Doswell, Va. (map ID site \#26) } \\
\hline TN & 01671020 & 8-NAR005.42 & Jan85-Dec98 & Reg & Y & .2247 & .272 & .341 & -37 & 11 & NS & 0 \\
\hline NOx & 01671020 & 8-NAR005.42 & Jan85-Dec98 & Reg & Y & .7326 & .161 & .164 & -21 & 18 & NS & 1 \\
\hline TP & 01671020 & 8-NAR005.42 & Jan85-Dec98 & Reg & Y & .0001 & .110 & .065 & -50 & -30 & DN & 19 \\
\hline $\mathrm{DP}$ & 01671020 & 8-NAR005.42 & Jan85-Dec98 & - & - & - & - & - & - & - & - & - \\
\hline DIP & 01671020 & 8-NAR005.42 & Jan85-Dec98 & - & - & - & - & - & - & - & - & - \\
\hline TSS & 01671020 & 8-NAR005.42 & Jan85-Dec98 & Reg & Y & .0739 & 3.90 & 7.86 & -4 & 171 & NS & 0 \\
\hline \multicolumn{13}{|c|}{02013100 - Jackson River below Dunlap Creek at Covington, Va. (map ID site \#28) } \\
\hline TN & 02013100 & 2-JKS023.61 & Jan85-Dec98 & Reg & $\mathrm{Y}$ & .3602 & .438 & .448 & -19 & 8 & NS & 2 \\
\hline NOx & 02013100 & 2-JKS023.61 & Jan85-Dec98 & Reg & $\mathrm{Y}$ & .0041 & .130 & .226 & 13 & 54 & UP & 3 \\
\hline TP & 02013100 & 2-JKS023.61 & Jan85-Dec98 & Reg & $Y$ & .0001 & 2.29 & .399 & -84 & -89 & DN & 100 \\
\hline DP & 02013100 & 2-JKS023.61 & Jan85-Dec98 & - & - & - & - & - & - & - & - & - \\
\hline DIP & 02013100 & 2-JKS023.61 & Jan85-Dec98 & - & - & - & - & - & - & - & - & - \\
\hline TSS & 02013100 & 2-JKS023.61 & Jan85-Dec98 & Reg & $Y$ & .0965 & 7.03 & 8.16 & -2 & 37 & NS & 2 \\
\hline
\end{tabular}




\section{APPENDIX 3-TRENDS IN FLOW-ADJUSTED CONCENTRATION DATA FOR 9 RIVER INPUT MONITORING PROGRAM SITES AND 21 Multi-Agency Nontidal Program sites IN THE Chesapeake Bay Watershed}

Parameters: TN, total nitrogen; $\mathrm{DNH}$, dissolved ammonia; $\mathrm{TNH}$, total ammonia; NOx, total or dissolved nitrate, or, nitrite plus nitrate; DKN, dissolved ammonia plus organic nitrogen; TKN, total ammonia plus organic nitrogen; TP, total phosphorus; DP, dissolved phosphorus; DIP, dissolved inorganic phosphorus; TSS, total suspended solids; SED, suspended sediment.

Station: flow, USGS discharge site number; WQ, water-quality site number.

Statistics: POR, time period used in test; percentage less than detect, percentage of samples reported at less than the detection limit; test, regression (Reg), Kendall Theil (KT); log transformed; yes ( $\mathrm{Y}$ ) or no (N); $p$-value, measure of significance of regressor at 0.05 ; slope, regression slope; base median, median of first 2 years of record; status median, median of last 3 years of record; magnitude, minimum ( $\mathrm{min}$ ) and maximum (max) percentage change in trend for indicated period of record; tend direction, UP, down (DN), or not significant (NS); relative rank, each individual status concentration (milligrams per liter) compared to all others of the same parameter; shaded areas are significant at 95-percent confidence level; —, not applicable or insufficient data. 
Appendix 3. Trends in flow-adjusted concentration data for 9 River Input Monitoring Program sites and 21 Multi-Agency Nontidal Program sites in the Chesapeake Bay Watershed-Continued

\begin{tabular}{|c|c|c|c|c|c|c|c|c|c|c|c|}
\hline \multirow{3}{*}{ Parameter } & \multicolumn{2}{|c|}{ Station } & \multicolumn{9}{|c|}{ Statistics } \\
\hline & \multirow{2}{*}{ Flow } & \multirow{2}{*}{ WQ } & \multirow{2}{*}{ POR } & \multirow{2}{*}{$\begin{array}{l}\text { Percentage } \\
\text { less than } \\
\text { detect }\end{array}$} & \multirow{2}{*}{ Test } & \multirow{2}{*}{$\begin{array}{c}\mathrm{p} \text {-value } \\
0.05\end{array}$} & \multirow{2}{*}{$\begin{array}{l}\text { Base-median } \\
\text { concentration }\end{array}$} & \multirow{2}{*}{$\begin{array}{l}\text { Status-median } \\
\text { concentration }\end{array}$} & \multicolumn{2}{|c|}{ Magnitude } & \multirow{2}{*}{$\begin{array}{l}\text { Trend } \\
\text { direction }\end{array}$} \\
\hline & & & & & & & & & Minimum & Maximum & \\
\hline \multicolumn{12}{|c|}{01491000 - Choptank River near Greensboro, Md. (map ID site \#9) } \\
\hline TN & 01491000 & 01491000 & Jan85-Dec98 & 0 & $\mathrm{KT}$ & 0.0963 & - & - & -14 & 1 & NS \\
\hline TKN & 01491000 & 01491000 & Jan85-Dec98 & 0 & KT & .0000 & - & - & -41 & -58 & DN \\
\hline NOx & 01491000 & 01491000 & Jan85-Dec98 & .3 & $\mathrm{KT}$ & .0000 & - & - & 17 & 45 & UP \\
\hline TP & 01491000 & 01491000 & Jan85-Dec98 & 1.8 & KT & .0006 & - & - & -13 & -39 & DN \\
\hline DP & 01491000 & 01491000 & Jan85-Dec98 & 3.2 & $\mathrm{KT}$ & .5628 & - & - & -15 & 36 & NS \\
\hline DIP & 01491000 & 01491000 & Jan85-Dec98 & 4.4 & KT & .0634 & - & - & 0 & 69 & NS \\
\hline SED & 01491000 & 01491000 & Jan85-Dec98 & 0 & KT & .0000 & - & - & -33 & -69 & DN \\
\hline \multicolumn{12}{|c|}{01578310 - Susquehanna River at Conowingo, Md. (map ID site \#8) } \\
\hline TN & 01578310 & 01578310 & Jan85-Dec98 & 0 & KT & .0000 & - & - & -13 & -25 & DN \\
\hline TKN & 01578310 & 01578310 & Jan85-Dec98 & 0 & $\mathrm{KT}$ & .0000 & - & - & -56 & -71 & DN \\
\hline NOx & 01578310 & 01578310 & Jan85-Dec98 & 0 & KT & .5513 & - & - & -6 & 12 & NS \\
\hline TP & 01578310 & 01578310 & Jan85-Dec98 & 2.8 & $\mathrm{KT}$ & .0000 & - & - & -36 & -60 & DN \\
\hline DP & 01578310 & 01578310 & Jan85-Dec98 & 3.5 & $\mathrm{KT}$ & .0000 & - & - & -51 & -22 & DN \\
\hline DIP & 01578310 & 01578310 & Jan85-Dec98 & 16.1 & KT & .9190 & - & - & -60 & 32 & NS \\
\hline SED & 01578310 & 01578310 & Jan85-Dec98 & 0 & $\mathrm{KT}$ & .0069 & - & - & -8 & -42 & DN \\
\hline \multicolumn{12}{|c|}{01594440 - Patuxent River near Bowie, Md. (map ID site \#11) } \\
\hline TN & 01594440 & 01594440 & Jan85-Dec98 & 0 & KT & .0000 & - & - & -60 & -70 & DN \\
\hline TKN & 01594440 & 01594440 & Jan85-Dec98 & 0 & $\mathrm{KT}$ & .0000 & - & - & -68 & -78 & DN \\
\hline NOx & 01594440 & 01594440 & Jan85-Dec98 & 0 & KT & .0000 & - & - & -58 & -70 & DN \\
\hline TP & 01594440 & 01594440 & Jan85-Dec98 & .2 & KT & .0000 & - & - & -78 & -90 & DN \\
\hline DP & 01594440 & 01594440 & Jan85-Dec98 & 3.5 & KT & .0000 & - & - & -74 & -93 & DN \\
\hline DIP & 01594440 & 01594440 & Jan85-Dec98 & 4.1 & $\mathrm{KT}$ & .0000 & - & - & -60 & -85 & DN \\
\hline SED & 01594440 & 01594440 & Jan85-Dec98 & 0 & $\mathrm{KT}$ & .0000 & - & - & -52 & -72 & DN \\
\hline
\end{tabular}


Appendix 3. Trends in flow-adjusted concentration data for 9 River Input Monitoring Program sites and 21 Multi-Agency Nontidal Program sites in the Chesapeake Bay Watershed-Continued

\begin{tabular}{|c|c|c|c|c|c|c|c|c|c|c|c|}
\hline \multirow{3}{*}{ Parameter } & \multicolumn{2}{|c|}{ Station } & \multicolumn{9}{|c|}{ Statistics } \\
\hline & \multirow{2}{*}{ Flow } & \multirow{2}{*}{ WQ } & \multirow{2}{*}{ POR } & \multirow{2}{*}{$\begin{array}{l}\text { Percentage } \\
\text { less than } \\
\text { detect }\end{array}$} & \multirow{2}{*}{ Test } & \multirow{2}{*}{$\begin{array}{c}p \text {-value } \\
0.05\end{array}$} & \multirow{2}{*}{$\begin{array}{l}\text { Base-median } \\
\text { concentration }\end{array}$} & \multirow{2}{*}{$\begin{array}{l}\text { Status-median } \\
\text { concentration }\end{array}$} & \multicolumn{2}{|c|}{ Magnitude } & \multirow{2}{*}{$\begin{array}{c}\text { Trend } \\
\text { direction }\end{array}$} \\
\hline & & & & & & & & & Minimum & Maximum & \\
\hline \multicolumn{12}{|c|}{01646580 - Potomac River at Chain Bridge, Md. (map ID site \#28) } \\
\hline $\mathrm{TN}$ & 01646580 & PR01 & Jan85-Dec98 & 0 & KT & 0.2020 & - & - & 0 & 15 & NS \\
\hline TKN & 01646580 & PR01 & Jan85-Dec98 & 0 & KT & .0000 & - & - & -49 & -65 & DN \\
\hline NOx & 01646580 & PR01 & Jan85-Dec98 & .5 & $\mathrm{KT}$ & .0059 & - & - & 23 & 47 & UP \\
\hline TP & 01646580 & PR01 & Jan85-Dec98 & 2.8 & $\mathrm{KT}$ & .0000 & - & - & -60 & -40 & DN \\
\hline DP & 01646580 & PR01 & Jan85-Dec98 & 10.4 & KT & .0000 & - & - & -68 & -40 & DN \\
\hline DIP & 01646580 & PR01 & Jan85-Dec98 & 22 & $\mathrm{KT}$ & - & - & - & - & - & - \\
\hline SED & 01646580 & PR01 & Jan85-Dec98 & 0 & KT & .0000 & - & - & -47 & -95 & DN \\
\hline \multicolumn{12}{|c|}{01668000 - Rappahannock River near Fredericksburg, Va. (map ID site \#24) } \\
\hline $\mathrm{TN}$ & 01668000 & 01668000 & Jan88-Dec98 & 0 & $\mathrm{KT}$ & .0000 & - & - & -21 & -41 & DN \\
\hline NOx & 01668000 & 01668000 & Jan88-Dec98 & 7 & $\mathrm{KT}$ & .0196 & - & - & -3 & -30 & DN \\
\hline TP & 01668000 & 01668000 & Jan88-Dec98 & 2 & KT & .0000 & - & - & -41 & -76 & DN \\
\hline DIP & 01668000 & 01668000 & Jan88-Dec98 & 13 & $\mathrm{KT}$ & .8286 & - & - & -29 & 47 & NS \\
\hline TSS & 01668000 & 01668000 & Jan88-Dec98 & 18 & KT & .0043 & - & - & -22 & -93 & DN \\
\hline \multicolumn{12}{|c|}{01673000 - Pamunkey River near Hanover, Va. (map ID site \#25) } \\
\hline $\mathrm{TN}$ & 01673000 & 01673000 & Jan89-Dec98 & 0 & KT & .7790 & - & - & -12 & 10 & NS \\
\hline NOx & 01673000 & 01673000 & Jan89-Dec98 & 0 & KT & .0000 & - & - & 20 & 53 & UP \\
\hline TP & 01673000 & 01673000 & Jan89-Dec98 & 0 & KT & .2891 & - & - & -23 & 8 & NS \\
\hline DIP & 01673000 & 01673000 & Jan89-Dec98 & 11 & $\mathrm{KT}$ & .0000 & - & - & 69 & 262 & UP \\
\hline TSS & 01673000 & 01673000 & Jan89-Dec98 & 10 & $\mathrm{KT}$ & .7230 & - & - & -37 & 36 & NS \\
\hline \multicolumn{12}{|c|}{01674500 - Mattaponi River near Beulahville, Va. (map ID site \#27) } \\
\hline $\mathrm{TN}$ & 01674500 & 01674500 & Jan89-Dec98 & 0 & KT & .0000 & - & - & -21 & -37 & DN \\
\hline NOx & 01674500 & 01674500 & Jan89-Dec98 & 2 & KT & .0088 & - & - & -6 & -35 & DN \\
\hline TP & 01674500 & 01674500 & Jan89-Dec98 & 0 & KT & .0000 & - & - & -25 & -42 & $\mathrm{DN}$ \\
\hline DIP & 01674500 & 01674500 & Jan89-Dec98 & 14 & KT & .0092 & - & - & 0 & 93 & UP \\
\hline TSS & 01674500 & 01674500 & Jan89-Dec98 & 18 & KT & .3314 & - & - & -41 & 16 & NS \\
\hline
\end{tabular}


Appendix 3. Trends in flow-adjusted concentration data for 9 River Input Monitoring Program sites and 21 Multi-Agency Nontidal Program sites in the Chesapeake Bay Watershed-Continued

\begin{tabular}{|c|c|c|c|c|c|c|c|c|c|c|c|}
\hline \multirow{3}{*}{ Parameter } & \multicolumn{2}{|c|}{ Station } & \multicolumn{9}{|c|}{ Statistics } \\
\hline & \multirow{2}{*}{ Flow } & \multirow{2}{*}{ WQ } & \multirow{2}{*}{ POR } & \multirow{2}{*}{$\begin{array}{c}\text { Percentage } \\
\text { less than } \\
\text { detect }\end{array}$} & \multirow{2}{*}{ Test } & \multirow{2}{*}{$\begin{array}{c}\mathrm{p} \text {-value } \\
0.05\end{array}$} & \multirow{2}{*}{$\begin{array}{l}\text { Base-median } \\
\text { concentration }\end{array}$} & \multirow{2}{*}{$\begin{array}{l}\text { Status-median } \\
\text { concentration }\end{array}$} & \multicolumn{2}{|c|}{ Magnitude } & \multirow{2}{*}{$\begin{array}{l}\text { Trend } \\
\text { direction }\end{array}$} \\
\hline & & & & & & & & & Minimum & Maximum & \\
\hline \multicolumn{12}{|c|}{02035000 - James River at Cartersville, Va. (map ID site \#29) } \\
\hline TN & 02035000 & 02035000 & Jan88-Dec98 & 0 & $\mathrm{KT}$ & 0.0084 & - & - & -30 & -5 & DN \\
\hline NOx & 02035000 & 02035000 & Jan88-Dec98 & 2 & $\mathrm{KT}$ & .2672 & - & - & -15 & 4 & NS \\
\hline TP & 02035000 & 02035000 & Jan88-Dec98 & 0 & $\mathrm{KT}$ & .0000 & - & - & -69 & -44 & DN \\
\hline DIP & 02035000 & 02035000 & Jan88-Dec98 & 2 & $\mathrm{KT}$ & .0000 & - & - & -83 & -65 & DN \\
\hline TSS & 02035000 & 02035000 & Jan88-Dec98 & 12 & $\mathrm{KT}$ & .9290 & - & - & -26 & 49 & NS \\
\hline \multicolumn{12}{|c|}{02041650 - Appomattox River at Matoaca, Va. (map ID site \#30) } \\
\hline TN & 02041650 & 02041650 & Jan89-Dec98 & 0 & KT & .0000 & - & - & -27 & -11 & DN \\
\hline NOx & 02041650 & 02041650 & Jan89-Dec98 & 3 & KT & .0337 & - & - & -39 & -2 & DN \\
\hline TP & 02041650 & 02041650 & Jan89-Dec98 & 0 & $\mathrm{KT}$ & .0931 & - & - & -31 & 0 & NS \\
\hline DIP & 02041650 & 02041650 & Jan89-Dec98 & 17 & $\mathrm{KT}$ & .7426 & - & - & 0 & 118 & NS \\
\hline TSS & 02041650 & 02041650 & Jan89-Dec98 & 16 & $\mathrm{KT}$ & .5398 & - & - & -15 & 60 & NS \\
\hline
\end{tabular}

\section{MULTI-AGENCY SITES}

01531500 - Susquehanna River at Towanda, Pa. (map ID site \#1)

\begin{tabular}{|c|c|c|c|c|c|c|c|c|c|c|c|}
\hline $\mathrm{TN}$ & 01531500 & TOW & Jan89-Dec98 & 0 & KT & .0000 & 1.35 & 1.01 & -22 & -43 & DN \\
\hline NOx & 01531500 & TOW & Jan89-Dec98 & 0 & KT & .0000 & .744 & .631 & -21 & -42 & DN \\
\hline TP & 01531500 & TOW & Jan89-Dec98 & .4 & $\mathrm{KT}$ & .5226 & .048 & .056 & -45 & 35 & NS \\
\hline DP & 01531500 & TOW & Jan89-Dec98 & 1.1 & $\mathrm{KT}$ & .0000 & .031 & .024 & -37 & -65 & DN \\
\hline DIP & 01531500 & TOW & Jan89-Dec98 & 2.6 & KT & .0114 & .008 & .005 & -76 & 0 & DN \\
\hline SED & 01531500 & TOW & Jan89-Dec98 & 0 & KT & .4562 & .8 & 4.2 & -21 & -68 & NS \\
\hline
\end{tabular}

01540500 - Susquehanna River at Danville, Pa. (map ID site \#2)

\begin{tabular}{|c|c|c|c|c|c|c|c|c|c|c|c|}
\hline $\mathrm{TN}$ & 01540500 & DAN & Jan85-Dec98 & 0 & KT & .0000 & 1.51 & 1.18 & -22 & -36 & DN \\
\hline NOx & 01540500 & DAN & Jan85-Dec98 & 0 & KT & .0526 & .796 & .786 & -17 & 0 & NS \\
\hline TP & 01540500 & DAN & Jan85-Dec98 & .5 & KT & .0000 & .075 & .034 & -30 & -60 & DN \\
\hline DP & 01540500 & DAN & Jan85-Dec98 & 3.3 & KT & .0000 & .027 & .012 & -54 & -70 & DN \\
\hline DIP & 01540500 & DAN & Jan85-Dec98 & 20.4 & - & - & .019 & .008 & - & - & - \\
\hline SED & 01540500 & DAN & Jan85-Dec98 & .5 & KT & .0012 & 36.6 & 23.5 & -25 & -74 & DN \\
\hline
\end{tabular}


Appendix 3. Trends in flow-adjusted concentration data for 9 River Input Monitoring Program sites and 21 Multi-Agency Nontidal Program sites in the Chesapeake Bay Watershed-Continued

\begin{tabular}{|c|c|c|c|c|c|c|c|c|c|c|c|}
\hline \multirow{3}{*}{ Parameter } & \multicolumn{2}{|c|}{ Station } & \multicolumn{9}{|c|}{ Statistics } \\
\hline & \multirow{2}{*}{ Flow } & \multirow{2}{*}{$W Q$} & \multirow{2}{*}{ POR } & \multirow{2}{*}{$\begin{array}{l}\text { Percentage } \\
\text { less than } \\
\text { detect }\end{array}$} & \multirow{2}{*}{ Test } & \multirow{2}{*}{$\begin{array}{c}p \text {-value } \\
0.05\end{array}$} & \multirow{2}{*}{$\begin{array}{l}\text { Base-median } \\
\text { concentration }\end{array}$} & \multirow{2}{*}{$\begin{array}{l}\text { Status-median } \\
\text { concentration }\end{array}$} & \multicolumn{2}{|c|}{ Magnitude } & \multirow{2}{*}{$\begin{array}{c}\text { Trend } \\
\text { direction }\end{array}$} \\
\hline & & & & & & & & & Minimum & Maximum & \\
\hline \multicolumn{12}{|c|}{01553500 - West Branch Susquehanna River at Lewisburg, Pa. (map ID site \#3) } \\
\hline TN & 01553500 & LEW & Jan85-Dec98 & 0 & KT & 0.0000 & 1.17 & 0.89 & -16 & -31 & DN \\
\hline NOx & 01553500 & LEW & Jan85-Dec98 & 0 & KT & .1109 & .655 & .581 & -16 & 2 & NS \\
\hline TP & 01553500 & LEW & Jan85-Dec98 & .3 & KT & .0000 & .034 & .01 & -51 & -79 & DN \\
\hline DP & 01553500 & LEW & Jan85-Dec98 & 10.6 & KT & .0000 & .02 & .008 & -63 & -81 & DN \\
\hline DIP & 01553500 & LEW & Jan85-Dec98 & 29.9 & - & - & .011 & .007 & - & - & - \\
\hline SED & 01553500 & LEW & Jan85-Dec98 & .9 & $\mathrm{KT}$ & .9293 & 11.2 & 12.8 & -53 & 98 & NS \\
\hline \multicolumn{12}{|c|}{01567000 - Juniata River at Newport, Pa. (map ID site \#4) } \\
\hline TN & 01567000 & JUN & Jan85-Dec98 & 0 & $\mathrm{KT}$ & .0000 & 1.99 & 1.52 & -19 & -29 & DN \\
\hline NOx & 01567000 & JUN & Jan85-Dec98 & 0 & KT & .0000 & 1.53 & 1.2 & -13 & -23 & DN \\
\hline TP & 01567000 & JUN & Jan85-Dec98 & 0 & KT & .0000 & .073 & .038 & -39 & -62 & DN \\
\hline DP & 01567000 & JUN & Jan85-Dec98 & 1.2 & $\mathrm{KT}$ & .0000 & .043 & .018 & -47 & -65 & DN \\
\hline DIP & 01567000 & JUN & Jan85-Dec98 & 12.2 & KT & .0000 & .017 & .014 & -53 & -90 & DN \\
\hline SED & 01567000 & JUN & Jan85-Dec98 & .9 & KT & .0015 & 23.3 & 10.6 & -25 & -73 & DN \\
\hline \multicolumn{12}{|c|}{01576000 - Susquehanna River at Marietta, Pa. (map ID site \#6) } \\
\hline TN & 01576000 & MAR & Jan85-Dec98 & 0 & $\mathrm{KT}$ & .0000 & 1.62 & 1.34 & -25 & -41 & DN \\
\hline NOx & 01576000 & MAR & Jan85-Dec98 & 0 & $\mathrm{KT}$ & .0342 & 1.03 & 1.02 & -1 & -21 & DN \\
\hline TP & 01576000 & MAR & Jan85-Dec98 & .3 & KT & .0000 & .084 & .043 & -46 & -71 & DN \\
\hline DP & 01576000 & MAR & Jan85-Dec98 & 2.4 & KT & .0000 & .031 & .016 & -49 & -66 & DN \\
\hline DIP & 01576000 & MAR & Jan85-Dec98 & 23.8 & - & - & .008 & .008 & - & - & - \\
\hline SED & 01576000 & MAR & Jan85-Dec98 & 1.2 & KT & .0013 & 39.7 & 24.5 & -24 & -73 & DN \\
\hline \multicolumn{12}{|c|}{01576754 - Conestoga River at Conestoga, Pa. (map ID site \#7) } \\
\hline TN & 01576754 & CON & Jan85-Dec98 & 0 & KT & .3555 & 8.74 & 8.86 & -12 & 5 & NS \\
\hline NOx & 01576754 & CON & Jan85-Dec98 & 0 & $\mathrm{KT}$ & .3276 & 6.26 & 6.84 & -5 & 18 & NS \\
\hline TP & 01576754 & CON & Jan85-Dec98 & 0 & $\mathrm{KT}$ & .0000 & .382 & .139 & -44 & -67 & DN \\
\hline DP & 01576754 & CON & Jan85-Dec98 & 0 & $\mathrm{KT}$ & .0000 & .247 & 112 & -55 & -73 & DN \\
\hline DIP & 01576754 & CON & Jan85-Dec98 & .5 & KT & .0000 & .178 & .063 & -60 & -83 & DN \\
\hline SED & 01576754 & CON & Jan85-Dec98 & .9 & KT & .0060 & 56 & 55.9 & -13 & -64 & DN \\
\hline
\end{tabular}


Appendix 3. Trends in flow-adjusted concentration data for 9 River Input Monitoring Program sites and 21 Multi-Agency Nontidal Program sites in the Chesapeake Bay Watershed-Continued

\begin{tabular}{|c|c|c|c|c|c|c|c|c|c|c|c|}
\hline \multirow{3}{*}{ Parameter } & \multicolumn{2}{|c|}{ Station } & \multicolumn{9}{|c|}{ Statistics } \\
\hline & \multirow{2}{*}{ Flow } & \multirow{2}{*}{ WQ } & \multirow{2}{*}{ POR } & \multirow{2}{*}{$\begin{array}{l}\text { Percentage } \\
\text { less than } \\
\text { detect }\end{array}$} & \multirow{2}{*}{ Test } & \multirow{2}{*}{$\begin{array}{c}p \text {-value } \\
0.05\end{array}$} & \multirow{2}{*}{$\begin{array}{l}\text { Base-median } \\
\text { concentration }\end{array}$} & \multirow{2}{*}{$\begin{array}{l}\text { Status-median } \\
\text { concentration }\end{array}$} & \multicolumn{2}{|c|}{ Magnitude } & \multirow{2}{*}{$\begin{array}{c}\text { Trend } \\
\text { direction }\end{array}$} \\
\hline & & & & & & & & & Minimum & Maximum & \\
\hline \multicolumn{12}{|c|}{01570000 - Conodoguinet Creek near Hogestown, Pa. (map ID site \#5) } \\
\hline TN & 01570000 & WQN0213 & Jan85-Dec98 & 12 & $\mathrm{KT}$ & 0.1915 & - & - & -21 & -50 & NS \\
\hline NOx & 01570000 & WQN0213 & Jan85-Dec98 & - & - & - & - & - & - & - & - \\
\hline TP & 01570000 & WQN0213 & Jan85-Dec98 & 13 & $\mathrm{KT}$ & .0000 & - & - & -69 & -95 & DN \\
\hline DP & 01570000 & WQN0213 & Jan85-Dec98 & 20 & KT & .0000 & - & - & -85 & -110 & DN \\
\hline DIP & 01570000 & WQN0213 & Jan85-Dec98 & - & - & - & - & - & - & - & - \\
\hline TSS & 01570000 & WQN0213 & Jan85-Dec98 & - & - & - & - & - & - & - & - \\
\hline \multicolumn{12}{|c|}{01586000 - North Branch Patapsco River at Cedarhurst, Md. (map ID site \#12) } \\
\hline TN & 01586000 & NPA0165 & Jan85-Dec98 & 0 & $\mathrm{KT}$ & .0000 & - & - & 27 & 31 & UP \\
\hline NOx & 01586000 & NPA0165 & Jan85-Dec98 & 0 & $\mathrm{KT}$ & .0000 & - & - & 46 & 53 & UP \\
\hline TP & 01586000 & NPA0165 & Jan85-Dec98 & 7.6 & $\mathrm{KT}$ & .0000 & - & - & -75 & -82 & DN \\
\hline DIP & 01586000 & NPA0165 & Jan85-Dec98 & - & - & - & - & - & - & - & - \\
\hline TSS & 01586000 & NPA0165 & Jan85-Dec98 & 4.8 & $\mathrm{KT}$ & .0015 & - & - & -70 & -61 & DN \\
\hline \multicolumn{12}{|c|}{01592500 - Patuxent River near Laurel, Md. (map ID site \#10) } \\
\hline TN & 01592500 & РХT0809 & Jan85-Dec98 & 0 & $\mathrm{KT}$ & .0010 & - & - & 14 & 17 & UP \\
\hline NOx & 01592500 & РХT0809 & Jan85-Dec98 & 0 & $\mathrm{KT}$ & .0385 & - & - & 14 & 21 & UP \\
\hline TP & 01592500 & РХT0809 & Jan85-Dec98 & 2.4 & $\mathrm{KT}$ & .8396 & - & - & -8 & 0 & NS \\
\hline DIP & 01592500 & РХТ0809 & Jan85-Dec98 & - & - & - & - & - & - & - & - \\
\hline TSS & 01592500 & РХT0809 & Jan85-Dec98 & 2.4 & $\mathrm{KT}$ & .0238 & - & - & 52 & 76 & UP \\
\hline \multicolumn{12}{|c|}{01599000 - Georges Creek near Franklin, Md. (map ID site \#13) } \\
\hline TN & 01599000 & GEO0009 & Jan85-Dec98 & 0 & KT & .0000 & - & - & -31 & -35 & DN \\
\hline NOx & 01599000 & GEO0009 & Jan85-Dec98 & 0 & $\mathrm{KT}$ & .0328 & - & - & 69 & 222 & UP \\
\hline TP & 01599000 & GEO0009 & Jan85-Dec98 & 2.4 & $\mathrm{KT}$ & .0000 & - & - & -73 & -75 & DN \\
\hline DIP & 01599000 & GEO0009 & Jan85-Dec98 & - & - & - & - & - & - & - & - \\
\hline TSS & 01599000 & GEO0009 & Jan85-Dec98 & .6 & $\mathrm{KT}$ & .7241 & - & - & -13 & 0 & NS \\
\hline
\end{tabular}


Appendix 3. Trends in flow-adjusted concentration data for 9 River Input Monitoring Program sites and 21 Multi-Agency Nontidal Program sites in the Chesapeake Bay Watershed-Continued

\begin{tabular}{|c|c|c|c|c|c|c|c|c|c|c|c|}
\hline \multirow{3}{*}{ Parameter } & \multicolumn{2}{|c|}{ Station } & \multicolumn{9}{|c|}{ Statistics } \\
\hline & \multirow{2}{*}{ Flow } & \multirow{2}{*}{ WQ } & \multirow{2}{*}{ POR } & \multirow{2}{*}{$\begin{array}{l}\text { Percentage } \\
\text { less than } \\
\text { detect }\end{array}$} & \multirow{2}{*}{ Test } & \multirow{2}{*}{$\begin{array}{c}\mathrm{p} \text {-value } \\
0.05\end{array}$} & \multirow{2}{*}{$\begin{array}{l}\text { Base-median } \\
\text { concentration }\end{array}$} & \multirow{2}{*}{$\begin{array}{l}\text { Status-median } \\
\text { concentration }\end{array}$} & \multicolumn{2}{|c|}{ Magnitude } & \multirow{2}{*}{$\begin{array}{c}\text { Trend } \\
\text { direction }\end{array}$} \\
\hline & & & & & & & & & Minimum & Maximum & \\
\hline \multicolumn{12}{|c|}{01601500 - Wills Creek near Cumberland, Md. (map ID site \#14) } \\
\hline TN & 01601500 & WIL0013 & Jan85-Dec98 & 0 & $\mathrm{KT}$ & 0.0000 & - & - & -43 & -47 & DN \\
\hline NOx & 01601500 & WIL0013 & Jan85-Dec98 & 0 & $\mathrm{KT}$ & 8709 & - & - & 8 & 112 & NS \\
\hline TP & 01601500 & WIL0013 & Jan85-Dec98 & 17 & $\mathrm{KT}$ & .6495 & - & - & -29 & 0 & NS \\
\hline DIP & 01601500 & WIL0013 & Jan85-Dec98 & - & - & - & - & - & - & - & - \\
\hline TSS & 01601500 & WIL0013 & Jan85-Dec98 & 8.5 & $\mathrm{KT}$ & . 5798 & - & - & -10 & -73 & NS \\
\hline \multicolumn{12}{|c|}{01610000 - Potomac River at Paw Paw, W. Va. (map ID site \#15) } \\
\hline TN & 01610000 & РОТ2766 & Jan85-Dec98 & 0 & $\mathrm{KT}$ & .0007 & - & - & -19 & -23 & DN \\
\hline NOx & 01610000 & РОТ2766 & Jan85-Dec98 & 0 & $\mathrm{KT}$ & .0010 & - & - & 277 & 794 & UP \\
\hline TP & 01610000 & РОТ2766 & Jan85-Dec98 & 3.9 & $\mathrm{KT}$ & .0004 & - & - & -50 & -57 & DN \\
\hline DIP & 01610000 & РОT2766 & Jan85-Dec98 & - & - & - & - & - & - & - & - \\
\hline TSS & 01610000 & РОТ2766 & Jan85-Dec98 & 6 & $\mathrm{KT}$ & . 0233 & - & - & -43 & -55 & DN \\
\hline \multicolumn{12}{|c|}{01613000 - Potomac River at Hancock, Md. (map ID site \#16) } \\
\hline TN & 01613000 & РОТ2386 & Jan85-Dec98 & 0 & $\mathrm{KT}$ & .0000 & - & - & -33 & -126 & DN \\
\hline NOx & 01613000 & РОT2386 & Jan85-Dec98 & 0 & $\mathrm{KT}$ & .9278 & - & - & -12 & 8 & NS \\
\hline TP & 01613000 & РОT2386 & Jan85-Dec98 & 3.8 & $\mathrm{KT}$ & .0000 & - & - & -53 & -58 & DN \\
\hline DIP & 01613000 & РОТ2386 & Jan85-Dec98 & - & - & - & - & - & - & - & - \\
\hline TSS & 01613000 & РОТ2386 & Jan85-Dec98 & 6.7 & $\mathrm{KT}$ & .0639 & - & - & -43 & -82 & NS \\
\hline \multicolumn{12}{|c|}{01614500 - Conococheague Creek at Fairview, Md. (map ID site \#17) } \\
\hline TN & 01614500 & CON0180 & Jan85-Dec98 & 0 & KT & .0003 & - & - & -15 & -18 & DN \\
\hline NOx & 01614500 & CON0180 & Jan85-Dec98 & 0 & $\mathrm{KT}$ & .0611 & - & - & 10 & 16 & NS \\
\hline TP & 01614500 & CON0180 & Jan85-Dec98 & 6 & $\mathrm{KT}$ & .0000 & - & - & -53 & 4 & DN \\
\hline DIP & 01614500 & CON0180 & Jan85-Dec98 & - & - & - & - & - & - & - & - \\
\hline TSS & 01614500 & CON0180 & Jan85-Dec98 & 5.5 & $\mathrm{KT}$ & .0015 & - & - & -42 & -50 & DN \\
\hline
\end{tabular}


Appendix 3. Trends in flow-adjusted concentration data for 9 River Input Monitoring Program sites and 21 Multi-Agency Nontidal Program sites in the Chesapeake Bay Watershed-Continued

\begin{tabular}{|c|c|c|c|c|c|c|c|c|c|c|c|}
\hline \multirow{3}{*}{ Parameter } & \multicolumn{2}{|c|}{ Station } & \multicolumn{9}{|c|}{ Statistics } \\
\hline & \multirow{2}{*}{ Flow } & \multirow{2}{*}{ WQ } & \multirow{2}{*}{ POR } & \multirow{2}{*}{$\begin{array}{l}\text { Percentage } \\
\text { less than } \\
\text { detect }\end{array}$} & \multirow{2}{*}{ Test } & \multirow{2}{*}{$\begin{array}{c}p \text {-value } \\
0.05\end{array}$} & \multirow{2}{*}{$\begin{array}{l}\text { Base-median } \\
\text { concentration }\end{array}$} & \multirow{2}{*}{$\begin{array}{l}\text { Status-median } \\
\text { concentration }\end{array}$} & \multicolumn{2}{|c|}{ Magnitude } & \multirow{2}{*}{$\begin{array}{c}\text { Trend } \\
\text { direction }\end{array}$} \\
\hline & & & & & & & & & Minimum & Maximum & \\
\hline \multicolumn{12}{|c|}{01638500 - Potomac River at Point of Rocks, Md. (map ID site \#19) } \\
\hline TN & 01638500 & POT1595 & Jan85-Dec98 & 0 & KT & 0.0009 & - & - & -17 & -20 & DN \\
\hline NOx & 01638500 & POT1595 & Jan85-Dec98 & 0 & - & 0158 & - & - & 20 & 28 & DN \\
\hline TP & 01638500 & POT1595 & Jan85-Dec98 & 6 & KT & .0000 & - & - & -57 & -62 & DN \\
\hline DIP & 01638500 & POT1595 & Jan85-Dec98 & - & - & - & - & - & - & - & - \\
\hline TSS & 01638500 & POT1595 & Jan85-Dec98 & 3.6 & KT & . 0069 & - & - & -37 & -45 & DN \\
\hline \multicolumn{12}{|c|}{01643000 - Monocacy River at Reels Mill Road, Md. (map ID site \#18) } \\
\hline TN & 01643000 & MON0528 & Jan85-Dec98 & 0 & KT & .0000 & - & - & -49 & -53 & DN \\
\hline NOx & 01643000 & MON0528 & Jan85-Dec98 & 0 & KT & .5638 & - & - & -7 & -85 & NS \\
\hline TP & 01643000 & MON0528 & Jan85-Dec98 & 0 & $\mathrm{KT}$ & .0000 & - & - & -56 & -62 & DN \\
\hline DIP & 01643000 & MON0528 & Jan85-Dec98 & - & - & - & - & - & - & - & - \\
\hline TSS & 01643000 & MON0528 & Jan85-Dec98 & 0 & $\mathrm{KT}$ & .3766 & - & - & -16 & -30 & NS \\
\hline \multicolumn{12}{|c|}{01631000 - S. Fork Shenandoah River near Front Royal, Va. (map ID site \#20) } \\
\hline TN & 01631000 & 1BSSF003.56 & Jan85-Dec98 & 36 & - & - & - & - & - & - & - \\
\hline NOx & 01631000 & 1BSSF003.56 & Jan85-Dec98 & .8 & $\mathrm{KT}$ & .3420 & - & - & 2 & 5 & NS \\
\hline TP & 01631000 & 1BSSF003.56 & Jan85-Dec98 & 20 & $\mathrm{KT}$ & .0676 & - & - & - & - & NS \\
\hline DP & 01631000 & 1BSSF003.56 & Jan85-Dec98 & - & - & - & - & - & - & - & - \\
\hline DIP & 01631000 & 1BSSF003.56 & Jan85-Dec98 & - & - & - & - & - & - & - & - \\
\hline TSS & 01631000 & 1BSSF003.56 & Jan85-Dec98 & 41 & - & - & - & - & - & - & - \\
\hline \multicolumn{12}{|c|}{01634000 - N. Fork Shenandoah River near Strasburg, Va. (map ID site \#21) } \\
\hline TN & 01634000 & 1BNFS010.34 & Jan85-Dec98 & 20 & KT & .3035 & - & - & 7 & 17 & NS \\
\hline NOx & 01634000 & 1BNFS010.34 & Jan85-Dec98 & 3.2 & KT & .0514 & - & - & 23 & 35 & NS \\
\hline TP & 01634000 & 1BNFS010.34 & Jan85-Dec98 & 31 & - & - & - & - & - & - & - \\
\hline DP & 01634000 & 1BNFS010.34 & Jan85-Dec98 & - & - & - & - & - & - & - & - \\
\hline DIP & 01634000 & 1BNFS010.34 & Jan85-Dec98 & - & - & - & - & - & - & - & - \\
\hline TSS & 01634000 & 1BNFS010.34 & Jan85-Dec98 & 53 & - & - & - & - & - & - & - \\
\hline
\end{tabular}


Appendix 3. Trends in flow-adjusted concentration data for 9 River Input Monitoring Program sites and 21 Multi-Agency Nontidal Program sites in the Chesapeake Bay Watershed-Continued

\begin{tabular}{|c|c|c|c|c|c|c|c|c|c|c|c|}
\hline \multirow{3}{*}{ Parameter } & \multicolumn{2}{|c|}{ Station } & \multicolumn{9}{|c|}{ Statistics } \\
\hline & \multirow{2}{*}{ Flow } & \multirow{2}{*}{ WQ } & \multirow{2}{*}{ POR } & \multirow{2}{*}{$\begin{array}{c}\text { Percentage } \\
\text { less than } \\
\text { detect }\end{array}$} & \multirow{2}{*}{ Test } & \multirow{2}{*}{$\begin{array}{c}p \text {-value } \\
0.05\end{array}$} & \multirow{2}{*}{$\begin{array}{l}\text { Base-median } \\
\text { concentration }\end{array}$} & \multirow{2}{*}{$\begin{array}{l}\text { Status-median } \\
\text { concentration }\end{array}$} & \multicolumn{2}{|c|}{ Magnitude } & \multirow{2}{*}{$\begin{array}{c}\text { Trend } \\
\text { direction }\end{array}$} \\
\hline & & & & & & & & & Minimum & Maximum & \\
\hline \multicolumn{12}{|c|}{01666500 - Robinson River near Locust Dale, Va. (map ID site \#23) } \\
\hline TN & 01666500 & 3-ROB001.90 & Jan85-Dec98 & 43 & - & - & - & - & - & - & \\
\hline NOx & 01666500 & 3-ROB001.90 & Jan85-Dec98 & 0 & KT & 0.0060 & - & - & -17 & -23 & DN \\
\hline TP & 01666500 & 3-ROB001.90 & Jan85-Dec98 & 56 & - & - & - & - & - & - & - \\
\hline DP & 01666500 & 3-ROB001.90 & Jan85-Dec98 & - & - & - & - & - & - & - & - \\
\hline DIP & 01666500 & 3-ROB001.90 & Jan85-Dec98 & - & - & - & - & - & - & - & - \\
\hline TSS & 01666500 & 3-ROB001.90 & Jan85-Dec98 & 23 & - & - & - & - & - & - & - \\
\hline \multicolumn{12}{|c|}{01671020 - North Anna River at Hart Corner near Doswell, Va. (map ID site \#26) } \\
\hline TN & 01671020 & 8-NAR005.42 & Jan85-Dec98 & 62 & - & - & - & - & - & - & - \\
\hline NOx & 01671020 & 8-NAR005.42 & Jan85-Dec98 & 20 & KT & .6587 & - & - & -7 & 0 & NS \\
\hline TP & 01671020 & 8-NAR005.42 & Jan85-Dec98 & 35 & - & - & - & - & - & - & - \\
\hline DP & 01671020 & 8-NAR005.42 & Jan85-Dec98 & - & - & - & - & - & - & - & - \\
\hline DIP & 01671020 & 8-NAR005.42 & Jan85-Dec98 & - & - & - & - & - & - & - & - \\
\hline TSS & 01671020 & 8-NAR005.42 & Jan85-Dec98 & 57 & - & - & - & - & - & - & - \\
\hline \multicolumn{12}{|c|}{02013100 - Jackson River below Dunlap Creek at Covington, Va. (map ID site \#28) } \\
\hline TN & 02013100 & 2-JKS023.61 & Jan85-Dec98 & 46 & - & - & - & - & - & - & - \\
\hline NOx & 02013100 & 2-JKS023.61 & Jan85-Dec98 & 5.7 & KT & .4423 & - & - & 4 & 10 & NS \\
\hline TP & 02013100 & 2-JKS023.61 & Jan85-Dec98 & 2.1 & KT & .0000 & - & - & -119 & -124 & DN \\
\hline DP & 02013100 & 2-JKS023.61 & Jan85-Dec98 & - & - & - & - & - & - & - & - \\
\hline DIP & 02013100 & 2-JKS023.61 & Jan85-Dec98 & - & - & - & - & - & - & - & - \\
\hline TSS & 02013100 & 2-JKS023.61 & Jan85-Dec98 & 9.9 & $\mathrm{KT}$ & .1102 & - & - & -28 & 16 & NS \\
\hline
\end{tabular}

